\title{
THE INFLUENCE OF INSTITUTIONAL INVESTORS ON ANALYST EARNINGS FORECAST PROPERTIES
}

\author{
A Dissertation \\ by \\ PAUL A. WONG
Submitted to the Office of Graduate and Professional Studies of Texas A\&M University
in partial fulfillment of the requirements for the degree of
DOCTOR OF PHILOSOPHY

$\begin{array}{ll}\text { Chair of Committee, } & \text { Lynn L. Rees } \\ \text { Committee Members, } & \text { Shane A. Johnson } \\ & \text { Nathan Y. Sharp } \\ & \text { Senyo Y. Tse } \\ \text { Head of Department, } & \text { James J. Benjamin }\end{array}$

August 2015

Major Subject: Accounting

Copyright 2015 Paul A. Wong 


\begin{abstract}
In this study, I examine the institutional investor demand for analyst information and its effect on earnings forecast properties. Analysts are motivated to fulfill their clients' demand for information, and institutional investors are sell-side analysts' most important client type. Following utility maximization and time allocation theory, analysts likely prioritize their time to maximize their utility and prioritize firms with greater institutional investor demand for information. I find that analysts report more accurate forecasts for firms with greater institutional ownership, and this association is primarily driven by transient institutions, non-investment advisor institutions, institutions that do not specialize in growth firms, and institutions that specialize in value firms. In contrast, I find evidence that analysts are more likely to issue bold earnings forecasts for firms with greater ownership by institutions that are more likely to value private information (e.g., investment advisor institutions with transient investments). These findings suggest that institutional ownership influences analysts' decision making and resource allocation, and analysts' forecasts cater to the information demands of their clients.
\end{abstract}




\section{DEDICATION}

To my wonderful, patient, and supportive wife. 


\section{ACKNOWLEDGEMENTS}

I acknowledge my dissertation committee for their continued encouragement and feedback throughout the dissertation process: Lynn Rees (chair), Shane Johnson, Nathan Sharp, and Senyo Tse. I appreciate the helpful comments from Joseph Chen, Steve Crawford, Chad Lawson, Michael, Mikhail, Volkan Muslu, Adrienne Rhodes, Hollis Skaife, Ayako Yasuda, and the workshop participants at Texas A\&M University, the University of California Davis, the University of Houston, and the University of Illinois at Chicago. I am thankful to my fellow Texas A\&M University Accounting Ph.D. students, and the financial support of Mays Business School. All mistakes in this study are my own. 


\section{TABLE OF CONTENTS}

Page

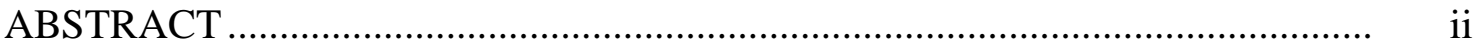

DEDICATION

ACKNOWLEDGEMENTS ........................................................................ iv

TABLE OF CONTENTS ...........................................................................

1. INTRODUCTION .............................................................................

2. MOTIVATION AND HYPOTHESIS DEVELOPMENT ................................ 7

2.1 Resource Constraints and Utility Maximization ............................ 7

2.2 Earnings Forecast Boldness .......................................................... 10

2.3 Earnings Forecast Accuracy ......................................................... 11

2.4 Institutional Investor Type ...................................................... 12

3. DATA AND RESEARCH DESIGN ......................................................... 14

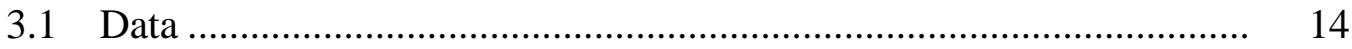

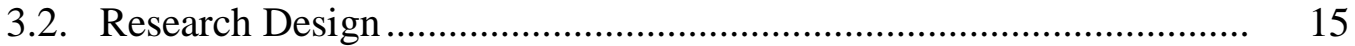

3.2.1 Earnings Forecast Boldness ................................................... 15

3.2.2 Earnings Forecast Accuracy .............................................. 18

3.2.3 Analyst Characteristics, Forecast Accuracy, and Firm Characteristic Transformations ............................................... 19

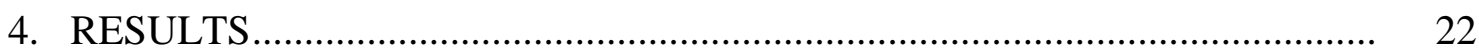

4.1 Descriptive Statistics ................................................................ 22

4.2 Multivariate Results ........................................................................ 24

4.2.1 Determinants of Institutional Ownership .............................. 24

4.2.2 Earnings Forecast Boldness and Accuracy ............................. 24

4.2.3 Institutional Investor Type ............................................... 27

5. ADDITIONAL ANALYSES ................................................................ 29

5.1 Optimistically Bold Forecasts .................................................... 29 
5.2 Leader Follower Analysts ................................................................ 31

5.3 Forecast Frequency ..................................................................... 31

5.4 Cross-Sectional Tests ................................................................ 32

5.5 Firm-Level Institutional Ownership ............................................ 34

5.6 Blockholder Investors ............................................................... 35

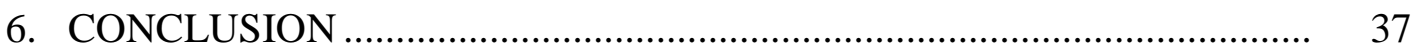

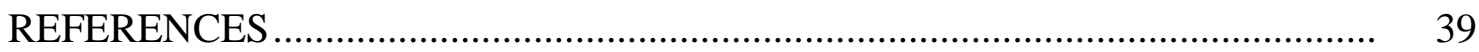

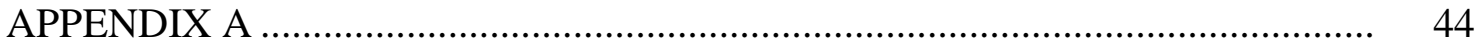

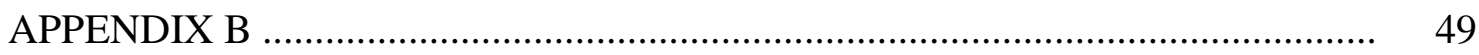

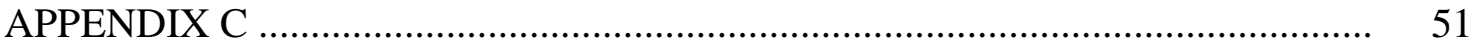




\section{INTRODUCTION}

In this study, I examine how institutional investors' demand for timely and relevant information affects analyst earnings forecast properties. I extend the literature on analyst decision making, incentives, and forecast properties to understand the circumstances that motivate analysts to issue forecasts that are valuable to investors. Financial analysts, like all individuals, experience resource constraints due to their various responsibilities, which may force analysts to prioritize their responsibilities and the firms they follow. Using economic theory on utility maximization and time allocation theory, I investigate whether the information demand from institutional investors, analysts' most important clientele, influences analysts to prioritize research activities on specific firms they follow. Specifically, I test whether earnings forecast boldness and accuracy vary with the institutional ownership of the firm, where earnings forecast boldness represents the analyst's private information and measures the estimate's deviation from the consensus estimate.

An important sell-side financial analyst objective is to provide valuable forecasts to investors (Beyer, Cohen, Lys, and Walther 2010), and financial analysts are important intermediaries between firms and investors. Investors rely on analysts to provide valuable information to make timely investment decisions (Brown, Call, Clement, and Sharp 2015). Prior studies find various associations between analyst earnings forecast properties and analyst characteristics (e.g., Stickel 1995; Mikhail, Walther, and Willis 1997; Clement 1999; Jacob, Lys, and Neale 1999; Clement and Tse 2003, 2005; Bae, 
Stulz, and Tan 2008). For instance, experienced analysts are more likely to issue bold and more accurate earnings forecasts (Clement and Tse 2005), while inexperienced analysts tend to issue earnings forecasts that converge toward other analysts' estimates (Hong, Kubik, and Solomon 2000). These studies develop an important foundation to explain why analysts following the same firm might forecast differently. However, prior studies generally ignore analyst incentives associated with each firm an analyst follows. These incentives could play an important role in determining each firm's importance to an analyst.

Time allocation theory states individuals have a limited amount of time to allocate to work and leisure, and individuals allocate their time between activities to maximize their utility (Becker 1965). Similarly, analysts have limited time and resources to gathering information about the firms they follow. Therefore, analysts may not be able to issue valuable forecasts for every firm they cover. Thus, analysts must decide how to best allocate their resources across the firms they follow to maximize their ability to meet their objectives.

I use institutional ownership to measure investor demand for analyst information. Institutional investors are analysts' most important clients, and institutional investors demand timely and relevant information (Brown et al. 2015). As a result, analysts are incentivized to provide timely and relevant firm information to fulfill institutional investors' information demand. Furthermore, institutional ownership and the information demanded from institutional investors are likely to vary across the firms an analyst follows. Therefore, I posit that analysts allocate greater resources toward researching 
firms with greater institutional ownership, and earnings forecast boldness and accuracy will vary systematically with the institutional ownership of the firms an analyst follows.

To address my research question, I create a measure of the demand for analyst information. This measure is calculated by the number of institutional investors with ownership in the firm scaled by the number of analysts covering the firm. The number of institutional investors with ownership in the firm represents the number of potential buyers of analyst reports and the institutional demand for analyst information, while the number of analysts issuing earnings forecasts represents the supply of analyst information about a firm. Analysts may view high ratios as a means to supply information to a large number of clients while facing low competition from other analysts, and analysts may prioritize and allocate greater resources to these firms. If analysts are incentivized to supply institutional investors with valuable firm information, then I expect analysts to issue bold and more accurate earnings forecasts for firms with greater institutional ownership.

Using a sample of annual earnings forecasts from 2002 to 2010, I find evidence that analysts are no more likely to issue bold earnings forecasts for firms with greater institutional ownership, but analysts report more accurate earnings forecasts for firms with greater institutional ownership. These findings provide evidence that analysts place importance on firms with greater institutional ownership, and the institutional investor demand for information incentivizes analysts to issue more accurate forecasts.

Research on institutional investors provides evidence that institutional investors are not a homogenous investor group (Bushee 2001; Abarbanell, Bushee, and Raedy 
2003; Bushee and Goodman 2007). Rather, institutional investors' investment decisions differ due to fiduciary restrictions and investment strategies. The fiduciary restrictions and investment strategies can affect an institution's information demands. For instance, transient institutions actively manage their investment portfolios, and institutions with relaxed fiduciary restrictions are able to invest in riskier securities. As a result, these institutions prioritize private information to quickly make informed investment decisions. However, other institutions invest in firms with predictable earnings, such as institutions with strong fiduciary restrictions, and these institutions may demand accurate projections of firm performance.

I partition institutional investors based on institutional investor type, and I find evidence that analysts are more likely to issue bold earnings forecasts for firms with greater ownership by investment advisor institutions with transient investments. Further, I find that analysts issue more accurate earnings forecasts for firms with greater ownership by transient institutions, non-investment advisor institutions, investment advisor institutions with transient investments, and institutions that do not specialize in growth firms. These findings suggest analysts issue forecasts with certain properties based on the types of institutions owning the firms they follow.

My study provides several contributions to the financial analyst literature that should be of interest to financial analysts, capital market participants, corporate managers, and academics. My study is the first, to my knowledge, to investigate how the supply and demand for analyst information impacts earnings forecast properties. I create new variables that measure each firm's importance to the analyst based on institutional 
investors' information demand for the firm. These variables provide a method to examine analyst incentives for each firm an analyst covers.

Further, I find evidence that analysts cater to the information demands of institutional investors. This result supports survey evidence from Brown et al. (2015) that suggests institutional investors are analysts' most important clients. Additionally, I contribute to the literature by providing evidence that analyst earnings forecast properties are affected by the presence of different types of institutional owners. These results indicate that analyst outputs are influenced not only by analyst characteristics but also by the characteristics of the firms the analyst follows, which allows investors to make informed investment decisions and develop market expectations with greater precision. The findings in my study are important in light of literature that questions whether analysts' outputs are useful in predicting future firm outcomes. For instance, some research finds that following analysts' stock recommendations is not a profitable investment strategy (e.g. Barniv, Hope, Myring, and Thomas. 2009; Drake, Rees, and Swanson 2011). Furthermore, research suggests analysts are incentivized to bias their outputs to curry favor with management (e.g., Lim 2001; Chen and Matsumoto 2006; Ke and Yu 2006; Mayew 2008; Brown et al. 2015). By examining analyst incentives, we can learn about analysts' decision making and the circumstances that influence analysts to issue earnings forecasts that are useful to investors (Schipper 1991; Brown 1993; Ramnath, Rock, and Shane 2008; Bradshaw 2011; Brown et al. 2015). The findings provided in this study partially illuminate the "black box" that is the analyst reporting environment. 
This study is organized as follows. Section 2 motivates the research question and discusses my hypotheses, and Section 3 discusses the data and methodology used to test the hypotheses. Section 4 states the empirical findings, while Section 5 contains additional analyses. Finally, Section 6 concludes the study. 


\section{MOTIVATION AND HYPOTHESES DEVELOPMENT}

\subsection{Resource Constraints and Utility Maximization}

Some economic literature examines decision making under resource constraints. Economic theory suggests that individuals make decisions to maximize utility. Becker (1965) introduces the theory of time allocation. Individuals are limited in the amount of time they have to work and to use the resources gained from working (or leisure); therefore, individuals must choose how to allocate their time between work and leisure. Becker (1965) posits that individuals allocate time between work and leisure to maximize their utility. Additionally, individuals choose among a set of similar alternatives based on the opportunity cost of expending resources on alternative options (Payne, Bettman, and Johnson 1988; Payne, Bettman, and Luce 1996; Rieskamp and Hoffrage 2008). As a result, individuals determine the combination of activities to maximize their expected benefit while minimizing their overall resource cost.

Analysts experience time and resource constraints due to their various responsibilities. Analysts are responsible for hosting and attending conferences and road shows, communicating with firms and investors, all while fulfilling their research and reporting duties for the various firms they follow. ${ }^{1}$ Further, clients expect analysts to provide access to management, which allows investors to make informed investment decisions (Green, Jame, Markov, and Subasi 2014; Solomon and Soltes 2015).

\footnotetext{
${ }^{1}$ Approximately 95 (80) percent of analysts responding to Brown et al. (2015) state they cover more than five (ten) firms at a time.
} 
Additionally, investors expect analysts to provide relevant information about entire industries and to exhibit industry expertise (Boni and Womack 2006; Hutton, Lee, and Shu 2012; Kadan, Madureira, Wang, Zach 2012), and sell-side analysts are rewarded for demonstrating industry expertise (Brown, Call, Clement, and Sharp 2014, 2015). The expectation to be an industry expert requires analysts to expend additional resources to gain knowledge about entire industries. As a result of their various responsibilities, financial analysts must divide their time and resources among their different duties. Analysts' earnings forecast properties can vary significantly across the firms they follow. As an example, I/B/E/S analyst \#321 followed 19 firms in 2010. Appendix B, Figure 1 depicts this analyst's earnings forecast accuracy relative to other analysts for each of the firms the analyst followed during 2010. The analyst was among the most accurate forecasters for six of the firms the analyst followed (or top quintile of relative earnings forecast accuracy) but was among the least accurate forecasters for five firms. This example illustrates that an analyst's relative earnings forecast accuracy differs across the firms the analyst follows, and it raises the question: what factors lead to differences in analysts' earnings forecast properties across the firms they follow?

Prior studies examine how analyst and brokerage characteristics explain the systematic differences in analyst earnings forecasts (e.g. Stickel 1995; Mikhail et al. 1997; Clement 1999; Jacob et al. 1999; Clement and Tse 2003, 2005; Bae et al. 2008). These studies provide a foundation to explain why an analyst may issue outputs with various properties for the firms he or she follows. However, firm characteristics could also affect analysts' forecasts. Figure 1 of Ramnath et al. (2008) depicts the analyst 
reporting environment. Analysts obtain information from a variety of sources, and various factors, such as analyst expertise and incentives, affect how analysts interpret information. As a result, analysts' earnings forecasts and recommendations are influenced by various factors and incentives. Each firm followed by an analyst possesses different characteristics - similar to how each analyst following a firm is different - and these characteristics provide different incentives for the analyst. The differences in firm characteristics may lead an analyst to prioritize the firms he or she follows, which may explain the differences in the analyst's earnings forecast properties.

Firms' institutional ownership provides an opportunity to study analyst incentives and resource allocation. Analysts are incentivized to fulfill client demand for information, specifically the demand from institutional investors. Institutional investors are analysts' most important client group (Brown et al. 2015), and institutional investors manage large investment funds. These investment funds provide institutional investors with the clout to demand timely and relevant firm and industry information from analysts. Furthermore, analyst compensation is determined, in part, by institutional investors (Maber, Groysberg, and Healy 2014; Brown et al. 2015²). Institutional investors vote for sell-side analysts in various annual rankings, and ranked analysts generally earn greater compensation (Maber et al. 2014). Thus, institutional investors exert significant influence on analysts.

\footnotetext{
${ }^{2}$ Brown et al. (2015) surveyed sell-side analysts. These analysts were asked to state the importance of nine items in determining the analyst's compensation. All nine items listed received an average importance rating above the midpoint of the scale used to measure the determinant's importance to compensation; however, the average importance rating for industry knowledge, standing in analyst rankings or broker votes, accessibility and/or responsiveness, and professional integrity were significantly greater than the other five items.
} 
Sell-side financial analysts follow multiple firms at any given time, and the number of institutional owners is likely to differ among the firms each analyst follows. The variance in the number of institutional owners means that the opportunity to curry favor with institutional investors differs among the firms the analyst follows. Appendix B, Figure 2 depicts the number of institutions with ownership in each of the firms I/B/E/S Analyst \#321 followed in 2010. The number of institutions varies significantly across firms. Eight of the 19 firms followed by the analyst had fewer than 200 different institutional investors, and three firms had more than 600 different institutional investors.

\subsection{Earnings Forecast Boldness}

Analysts obtain information about firms from various public and non-public sources, and private information enables an analyst to issue bold earnings forecasts, or forecasts that diverge from forecasts issued by other analysts (Trueman 1994). Institutional investors use and value private information to execute profitable stock trades (Bushee and Goodman 2007). As a result, analysts attract institutional investor attention by signaling they possess private information (Brown et al. 2014). As institutional investors are analysts' most important clients, the institutional investor demand for private information encourages analysts to obtain private information and issue bold earnings forecasts, and the likelihood of issuing a bold earnings forecast should increase with the institutional ownership of the firm. Thus, I hypothesize the following: 
H1: Analysts are more likely to issue bold earnings forecasts for firms with greater institutional ownership.

However, prior research also supports an alternative hypothesis. Analysts ignore their private information and converge, or herd, with other analysts under certain circumstances (Trueman 1994; Welch 2000). Analyst career concerns influence herding behaviors, and analysts are more likely to be terminated following the issuance of an inaccurate and bold earnings forecast (Hong et al. 2000). Analysts also risk losing access to management teams if they issue unfavorable earnings forecasts (Brown et al. 2015). Therefore, an analyst may face greater career risks after issuing a bold earnings forecast. Finally, individuals increase their risk aversion as potential benefits increase (Kachelmeier and Shehata 1992; Holt and Laury 2002). For these reasons, analysts may choose to ignore private information and issue forecasts that converge towards other analysts' estimates for firms with greater institutional ownership.

\subsection{Earnings Forecast Accuracy}

In addition to providing the market with new and relevant firm information, analysts' earnings forecasts provide market participants with a firm's expected performance (Fried and Givoly 1988; O’Brien 1988), and analysts are rewarded for accurately forecasting earnings (Stickel 1992; Hong and Kubik 2003). ${ }^{3}$ Accurate forecasters are more likely to be recruited and hired by more prestigious brokerage firms, which generally pay analysts more than less prestigious brokerage firms (Hong

\footnotetext{
${ }^{3}$ Brown et al. (2015) find earnings forecast accuracy is important to analyst compensation; however, it is the least important factor present to surveyed analysts.
} 
and Kubik 2003). Furthermore, analysts enhance client relationships by issuing accurate forecasts. Analysts are motivated to issue accurate forecasts to fulfill the demand from their investor clients (Brown et al. 2015). Because the demand for analyst information varies across the firms an analyst follows, analysts can efficiently fulfill their clients' information demand by issuing accurate forecasts for firms with greater institutional ownership. Therefore, I hypothesize the following relation:

H2: Analysts issue more accurate earnings forecasts for firms with greater institutional ownership.

\subsection{Institutional Investor Type}

While institutional investors are sophisticated investors, some research suggests institutional investors cannot be treated as a homogeneous group because of their varying fiduciary restrictions and investment strategies (Lang and McNichols 1997; Bushee 2001; Abarbanell et al. 2003; Bushee and Goodman 2007). These restrictions and strategies lead some institutions to rely more on private information than others. For instance, transient institutions focus on short-term investments and frequently trade in and out of investments (Porter 1992, 42-49; Bushee 1998; Bushee 2001; Ke and Petroni 2004). ${ }^{4}$ Transient investors seek short-term profits and require private information to make informed stock trades. In addition, fiduciary restrictions may force institutions to invest in firms that appear to be safer investments with less uncertainty (Bushee 2001), and institutions with lax restrictions may seek private information to justify riskier

\footnotetext{
${ }^{4}$ Bushee (1998) classifies each institutional investor manager in Thomson Reuters into one of three categories: dedicated, transient, and quasi-indexer.
} 
investments. As a result, the information demands of institutional investors may differ based on the investment strategies and fiduciary restrictions of institutions, and analysts may issue forecasts with different properties depending on the types of institutions that own the firm. Bushee and Goodman (2007) identify transient institutions, institutions investing in growth firms or value firms only, and investment advisor institutions as possible institutions that trade on private information. I hypothesize the following: H3a: Analysts are more likely to issue bold earnings forecasts for firms with greater ownership by institutions prioritizing private information.

H3b: Analysts issue more accurate earnings forecasts for firms with greater ownership by institutions that do not prioritize private information. 


\section{DATA AND RESEARCH DESIGN}

\subsection{Data}

I use a sample of annual earnings forecasts from the $\mathrm{I} / \mathrm{B} / \mathrm{E} / \mathrm{S}$ database from the years 2002 to $2010 .^{5}$ I retain the last earnings forecast issued before the earnings announcement for each analyst following the firm. I eliminate stale forecasts by removing forecasts issued more than 90 days prior to the earnings announcement. I require firms in my sample to be followed by at least two analysts during the fiscal period, and each analyst must follow at least two firms during the period. This allows me to make meaningful comparisons across analysts following a firm and across the firms each analyst follows. All analysts must also issue an annual earnings forecast for the firm in the prior fiscal period as I control for the analyst's prior year forecast accuracy.

I calculate analyst characteristics using I/B/E/S data, and I remove any observation with missing analyst characteristic values. I collect equity and debt offering information from Thomson One to determine whether the analyst is employed by a brokerage capable of providing underwriting services. ${ }^{6}$ I use Thomson Reuters to obtain

\footnotetext{
${ }^{5}$ I choose to use post-Regulation Fair Disclosure ("Reg FD") period forecasts and recommendations to eliminate the effect of the significant changes in the analyst regulatory environment caused by new regulations.

${ }^{6}$ Thomson One maintains a list of debt and equity issuances. This list also includes the amount of debt and equity issued and the name of the brokerage underwriting the offering. I use this list to identify brokerages capable of providing underwriting services based on prior completed offerings. I identify the name of the brokerage firm employing the analyst from the I/B/E/S recommendation detail file. I then determine whether the brokerage firm employing the analyst has the ability to offer underwriting services by matching the brokerage firm name from $\mathrm{I} / \mathrm{B} / \mathrm{E} / \mathrm{S}$ with the brokerage firm names listed as underwriters in the Thomson One list.
} 
institutional ownership information. ${ }^{7}$ I obtain firm financial statement data and GICS industry classifications ${ }^{8}$ from Compustat and stock data from CRSP. I use the Institutional Investor All-American lists to determine the analyst's All-Star status. Finally, I use RavenPack Data Analytics to obtain unique news stories published by the business press. ${ }^{9,10}$ My final sample contains 67,427 annual earnings forecasts.

\subsection{Research Design}

\subsubsection{Earnings Forecast Boldness}

My first hypothesis examines the determinants of bold earnings forecasts. I expand on the model used by Clement and Tse (2005) by including a measure of the demand for analyst information based on institutional ownership in the firm. I estimate the following logistic regression:

$$
\begin{aligned}
\operatorname{Logit}\left(\text { Bold }_{i j t}\right)= & \beta_{0}+\beta_{1} \text { Inst_Inv_std }_{i j t}+\text { Analyst Controls }+ \text { Firm Controls }+ \\
& \text { Year Fixed Effects }+ \text { Industry Fixed Effects }
\end{aligned}
$$

The dependent variable is Bold $_{i j t}$, which is a dichotomous variable equal to one if the analyst revises his or her earnings forecast away from the prior consensus estimate

\footnotetext{
7 The SEC requires all institutional investors managing portfolios worth $\$ 100$ million or more to report their holdings to the SEC on a quarterly basis. Institutions required to report their holdings "can include investment advisers, banks, insurance companies, broker-dealers, pension funds, and corporations" (U.S. Securities and Exchange Commission 2014).

${ }^{8}$ GICS industry and sector classifications are closely linked to the industries and sectors identified by financial analysts (Ramnath 2002; Bhojraj, Lee, and Oler 2003; Hui and Yeung 2012; Rees, Sharp, and Wong 2014).

${ }^{9}$ RavenPack Data Analytics captures news articles published by the business press for over 30,000 firms worldwide. RavenPack provides the date and timestamp the news article was published. It also provides a measure to determine the uniqueness (or novelty) of the article. For the purpose of this study, I obtain the original and most unique article published about a specific story for the firm.

${ }^{10}$ The total number of business press stories is equal to zero if RavenPack does not cover the firm or if no news stories were published about the firm. Approximately 2,700 observations (or 4 percent of my dataset) have no business press coverage. In untabulated results, I estimate my regressions excluding observations without business press coverage. My reported results are consistent with results excluding observations without business press coverage.
} 
and the earnings forecast is more than one standard deviation away from the prior consensus. I choose this measure for boldness because buy-side analysts state that forecasts deviating from the consensus attract their attention (Brown et al. 2014). The standard deviation of the prior consensus provides a relative distance from the consensus earnings forecast, and this statistic allows me to determine if the analyst's forecast deviates from other analysts. My independent variable of interest is Inst_Inv_std $d_{i j t}$, which measures institutional ownership and the institutional demand for analyst information. It is calculated as the number of institutions with ownership in the firm, ${ }^{11}$ scaled by the number of analysts following the firm during the year. The number of institutional investors with ownership in the firm represents the number of potential institutional clients demanding analyst information about the firm, while the number of analysts following the firm represents the supply of analyst information. I scale by the number of analysts following the firm to capture competition among analysts for the attention of the institutional owners. This value is transformed relative to the value for the other firms the analyst follows. I hypothesize that Inst_Inv_std ${ }_{i j t}$ is positively associated with the issuance of bold earnings forecasts.

I rely on Clement and Tse $(2003,2005)$ to identify control variables that are likely to affect the analyst's information environment. I control for the number of days elapsed since the last earnings forecast issued by any analyst following the firm (Days_Elapsed_std $\left.{ }_{i j t}\right)$ and the number of days from the issuance of the forecast to the

\footnotetext{
${ }^{11}$ I determine institutional ownership based on the 13-F filings in the quarter prior to the earnings forecast date.
} 
date of the earnings announcement $\left(\right.$ Horizon_std $\left.d_{i j t}\right)$. Lag_Accuracy_std ${ }_{i j t}$ measures the analyst's relative forecast accuracy for the firm in the prior year. I also control for the analyst's general (Gen_Exp_std $\left.d_{i j t}\right)$ and firm-specific $\left(F i r m \_E x p \_s t d_{i j t}\right)$ forecasting experience. I control for the number of firms (Follow_std $\left.d_{i j t}\right)$ and the number of GICS sectors $\left(\right.$ Sectors_std $\left.d_{i j t}\right)$ the analyst follows, and the number of forecasts the analyst issued for the firm during the year (Forecast_Freq_std ${ }_{i j t}$ ). I further control for factors that indicate an analyst may have access with management (Allstar $i$, Optimistic_Rec $\left.c_{i j t}\right)$. AllStar analysts receive greater access to management (Mayew 2008; Mayew, Sharp, and Venkatachalam 2013); therefore, they may have greater access to private information than non-All-Star analysts. Allstar $i j t$ is a dichotomous variable equal to one if the analyst received recognition as an Institutional Investor All-American in the prior year. ${ }^{12}$ Furthermore, optimistic recommendations increase an analyst's access to management (Mayew 2008). Therefore, I control for management access-seeking behaviors by including Optimistic_Rec $c_{i j t}$ in the model, where Optimistic_Rec $c_{i j t}$ is a dichotomous variable equal to one if the analyst's outstanding recommendation issued by the analyst is more optimistic than the consensus recommendation for the firm issued by other analysts. I also control for brokerage size (Broker_Size_std $\left.{ }_{i j t}\right)$ and the brokerage's ability to underwrite debt or equity securities (Underwriter $r_{i j t}$ ).

Finally, I control for firm characteristics. Lang and Lundholm (1996) document that analysts are more accurate for firms that disclose more information. Therefore, I

\footnotetext{
${ }^{12}$ Institutional Investor ranks analysts in four tiers. For the purpose of this study, I combine all four tiers of the All-American rankings into one category of All-Star analysts to compare All-Star versus non-All-Star analysts.
} 
control for the firm's earnings guidance disclosure policy (Guidance ${ }_{j t}$ ), which is a dichotomous variable equal to one if the firm released earnings guidance within 90 days prior to the forecast announcement. I control for firm assets $\left(A T_{\_} s t d_{i j t}\right)$, firm income $\left(I B \_s t d_{i j t}\right)$, the number of analyst following the firm $\left(\right.$ Following_std $\left.d_{i j t}\right)$, and business press coverage $\left(N e w s \_s t d_{i j t}\right)$. In addition, I control for stock characteristics, such as market-value of equity $\left(M V E_{-} s t d_{i j t}\right)$, bid-ask spread $\left(S p r e a d \_s t d_{i j t}\right)$, and share turnover (Turnover_st $\left.d_{i j t}\right)$. The firm characteristics are measured relative to the other firms the analyst follows.

\subsubsection{Earnings Forecast Accuracy}

My second hypothesis examines earnings forecast accuracy. I expand on the model used by Clement and Tse (2005) to determine the factors associated with an accurate earnings forecast.

$$
\begin{gathered}
\text { Accuracy_std }_{i j t}=\beta_{0}+\beta_{1} \text { Inst_Inv_std }_{i j t}+\beta_{2} \text { Bold }_{i j t}+\text { Analyst Controls }+ \\
\text { Firm Controls }+ \text { Year Fixed Effects }+ \\
\text { Industry Fixed Effects }
\end{gathered}
$$

Equations (1) and (2) are similar; however, the dependent variable in Equation (2) is relative earnings forecast accuracy (Accuracy_std $d_{i j t}$ ). The variable of interest is Inst_Inv_std ${ }_{i j t}$. Based on $\mathrm{H} 2$, I expect Inst_Inv_std ${ }_{i j t}$ to be positively associated with earnings forecast accuracy. Following Clement and Tse (2005), I control for Bold Bitt $_{\text {in }}$ Equation (2). Analysts issuing bold forecasts indicate private information, which may to lead to greater forecast accuracy. 
To test $\mathrm{H} 3 \mathrm{a}$ and $\mathrm{H} 3 \mathrm{~b}$, I modify Equations (1) and (2) and replace Inst_Inv_std ${ }_{i j t}$ with measures that define various types of institutional investors. I use institutional investor classifications in Abarbanell et al. (2003) to partition institutional investors into groups. I create additional institutional investor variables that measure the number of transient (and non-transient) institutional owners, the number of institutional owners specializing in growth firms or value firms (and non-growth firms or non-value firms, respectively), and the number investment advisor (and non-investment advisor) institutions. I also create a variable to measure the number of investment advisor institutions with transient investments (and non-investment advisor institutions with transient investments). Following Goodman and Bushee (2007), I estimate my regressions using one institution group at a time. I expect analysts to fulfill the specific information demands of their clients by issuing bold earnings forecasts for firms with greater ownership by institutions that rely on private information to make investment decisions, and I expect analysts to issue more accurate earnings forecasts for firms with greater ownership by institutions that do not rely on private information.

\subsubsection{Analyst Characteristics, Forecast Accuracy, and Firm Characteristic}

\section{Transformations}

Following Clement and Tse (2003, 2005), I transform analyst, forecast, and firm characteristic values to range from 0 to 1 . Analyst characteristics are transformed based on their relative values among the analysts following the firm during the year. These characteristics include Days_Elapsed $i j$, Horizon $_{i j t}$, Firm_Exp $p_{i j t}$, Gen_Exp $p_{i j t}$, 
Forecast_Freq $_{i j t}$,Follow $w_{i j}$,Sectors $s_{i j t}$, and Brokerage_Size $e_{i j t}$. I use the following equation to calculate the transformed variables:

$$
\text { Analyst_Characteristic_std }_{i j t}=\frac{\text { Raw_Characteristic }_{i j t}-\min \left(\text { Raw }_{-} \text {Characteristic } c_{i j t}\right)}{\max \left(\text { Raw_Characteristic }_{i j}\right)-\min \left(\text { Raw_Characteristic }_{i j t}\right)},
$$

where Raw_Characteristic $c_{i j t}$ is equal to the untransformed value, and $\max \left(\right.$ Raw_Characteristic $\left._{i j t}\right)$ and $\min \left(\right.$ Raw_Characteristic $\left._{i j t}\right)$ are the maximum and minimum value for the analysts issuing earnings forecasts for the firm during the year, respectively. An Analyst_Characteristic_std $d_{i j t}$ value equal to 1 indicates the analyst's untransformed value is greater than all other analysts following the firm during the year.

I transform the analyst's current and prior year earnings forecast accuracy. These variables compare the analyst's forecast accuracy for the firm during the year relative to all other analysts following the firm. The transformed accuracy variables range from 0 to 1 , where a value of 1 (0) indicates the analyst who issued the most (least) accurate forecasts for the firm during the year. I use the following equation to calculate the transformed forecast accuracy variables:

$$
\operatorname{Accuracy}_{-} s t d_{i j t}=\frac{\max \left(A F E_{j t}\right)-A F E_{i j t}}{\max \left(A F E_{j t}\right)-\min \left(A F E_{j t}\right)},
$$

where $A F E_{i j t}$ is equal to the absolute value of earnings forecast error, and $\max \left(A F E_{j t}\right)$ and $\min \left(A F E_{j t}\right)$ are equal to the maximum and minimum absolute value of earnings forecast error for the analysts following the firm during the year, respectively.

Finally, I transform firm characteristics (institutional ownership, firm assets, income, analyst following, news stories, and stock characteristics), and I create variables that measure characteristics relative to the other firms the analyst follows. This allows 
me to determine how firm characteristics within an analyst's portfolio affect analyst forecast characteristics. I use the following formula to transform firm characteristics:

$$
\begin{aligned}
& \text { Firm_Characteristic_std }_{i j t}= \\
& \frac{\text { Raw_Firm_Characteristic }_{i j t}-\text { min }\left(\text { Raw_Firm_Characteristic }_{j t}\right)}{\max \left(\text { Raw_Firm_Characteristic }_{j t}\right)-\min \left(\text { Raw }_{-} \text {Firm_Characteristic }_{j t}\right)},
\end{aligned}
$$

where Raw_Firm_Charactierstic $c_{i j t}$ is equal to the firm characteristic value, and $\max \left(\right.$ Raw_Firm_Characteristic $\left.c_{j t}\right)$ and $\min ($ Raw_Firm_Characteristic $j$ jt $)$ are equal to the maximum and minimum firm characteristic value for the firms the analyst follows, respectively. A Firm_Characterstic_std $d_{i j t}$ value equal to $1(0)$ indicates the firm with the greatest (least) characteristic value relative to other firms the analyst follows. 


\section{RESULTS}

\subsection{Descriptive Statistics}

I present all tables referenced in the manuscript in Appendix C. I present the descriptive statistics for the non-transformed variables used in my analyses in Table 1, Panel A. The descriptive statistics of analyst and brokerage characteristics are generally consistent with Clement and Tse (2005) with a few exceptions. Approximately 28 percent of observations in my sample are bold forecasts compared to approximately 73 percent of observations in Clement and Tse (2005). This is due to the different definitions of earnings forecast boldness used in the two studies. ${ }^{13}$ The sample mean forecast horizon is approximately 44 days. The average brokerage employs approximately 64 analysts compared to 30 analysts in Clement and Tse (2005), which suggests that my sample includes earnings forecasts issued by analysts employed at larger brokerage firms. The average analyst in my sample follows firms in approximately 2.19 GICS sectors. ${ }^{14}$

Table 1, Panel B, presents the descriptive statistics of the non-transformed institutional ownership variables. The average Inst_Inv $v_{i j t}$ value is 17.40 . This means that an average of 17.40 institutions own the firm for each analyst that follows it. Investment

\footnotetext{
${ }^{13}$ Clement and Tse (2005) define bold earnings forecasts as an indicator variable equal to one if the analyst's forecast is above both the analyst's prior forecast and the mean forecast immediately before the forecast revision or below both. It is set to 0 otherwise; whereas, I define a bold earnings forecast as a forecast that moves away from the consensus and is at least one standard deviation away from the consensus estimate.

${ }^{14}$ The GICS sector codes are broader in definition than the 2-digit SIC codes. This leads to more firms in each industry under the GICS sector definition and a lower average industry following.
} 
advisor institutions are the largest institutional investor group (mean IA_Inst_Inv $v_{i j t}=$ 11.21), while institutions specializing in growth firms represent the smallest institutional investor group (mean Growth_Inst_Inv $v_{i j t}=3.59$ ). Panel C presents the descriptive statistics for the transformed accuracy and control variables used in this study, and they are generally consistent with Clement and Tse (2005).

In Table 1, Panel D, I provide the descriptive statistics of the transformed institutional ownership variables. The mean (median) Inst_Inv_std ${ }_{i j t}$ value is equal to $0.39(0.32)$. The mean and median values for the various transformed institutional ownership variables are generally consistent with each other. The mean values range from 0.37 (Growth_Inst_Inv_std $\left.d_{i j t}\right)$ to 0.41 (Trans_Inst_Inv_std $\left.d_{i j t}\right)$, while the median values range from 0.28 (Growth_Inst_Inv_std $\left.d_{i j t}\right)$ to 0.35 (Trans_Inst_Inv_std $d_{i j t}$ and IA_Trans_Inst_Inv_std $\left.d_{i j t}\right)$.

Table 1, Panel E, presents the correlation table for the variables used in my analyses. Institutional ownership is negatively correlated with earnings forecast boldness and positively correlated with earnings forecast accuracy (p-value $<0.01$ ), which provides preliminary evidence that bold earnings forecasts are less accurate that other forecasts.. Additionally, earnings forecast boldness is negatively correlated with earnings forecast accuracy ( $\mathrm{p}$-value $<0.01$ ). Firm specific and general forecasting experience are highly correlated $(0.50, \mathrm{p}$-value $<0.01)$. However, tests do not indicate that my multivariate estimates are subject to multicollinearity. ${ }^{15}$

$\overline{{ }^{15} \text { Variation Inflation Factors (VIF) }}$ are less than 10 for all regressions. 


\subsection{Multivariate Results}

\subsubsection{Determinants of Institutional Ownership}

O’Brien and Bhushan (1990) find that institutional owners prefer to own firms with certain characteristics. I test whether institutional ownership by various types of institutions is associated with firm characteristics, such as size, income, bid-ask spread, share turnover, and media and analyst coverage. These results are reported in Table 2. Firms with the greatest level of institutional ownership within an analyst's portfolio of firms covered are likely to be larger in assets and market value, earn greater income, and receive greater media coverage. Further, firms with the greatest level of institutional ownership are also likely to have lower analyst coverage and share turnover. These associations are consistent regardless of the category of institution owning the firm. Bidask spread is generally not associated with institutional ownership; however, firms with greater ownership by institutions specializing in growth firms are likely to have larger bid-ask spreads. Due to these associations, I control for firm characteristics in Equations (1) and (2). ${ }^{16}$

\subsubsection{Earnings Forecast Boldness and Accuracy}

I hypothesize that earnings forecast boldness is positively associated with the firm's institutional ownership. Table 3, Column 1 reports the results of estimating Equation (1) with standard errors clustered by analyst. The area under the ROC is equal

\footnotetext{
${ }^{16}$ It is not evident that a strong instrumental variable exists, and weak instruments can bias in the regressions estimates (Bound, Jaeger, and Baker 1995). Therefore, I do not use a two-staged least squares methodology.
} 
to 0.62 . This suggests mediocre model fit. ${ }^{17}$ Contrary to my prediction, institutional ownership does not influence analysts to issue bold earnings forecasts (Inst_Inv $v_{i j t}=$ 0.008, $\mathrm{p}$-value $>0.10$ ). This may indicate that not all institutional investors demand private information from analysts, and analysts are not incentivized to issue bold earnings forecasts based on the institutional ownership of the firms the analyst follows. Thus, additional investigation is required to determine whether institutional ownership influences analyst behaviors.

The control variables follow results from prior literature with a few exceptions. Analyst firm and general forecast experience are not associated with earnings forecast boldness. Furthermore, the number of firms followed by the analyst is insignificant $\left(\right.$ Follow_std $_{i j t}=0.008$, p-value $\left.>0.10\right)$, while analysts are less likely to issue bold earnings forecast when they follow firms in multiple sectors $\left(\right.$ Sectors_std $_{i j t}=-0.126, \mathrm{p}$ value $<0.01)$. Additionally, All-Star analysts are 7.8 percent more likely to issue bold earnings forecasts than non-All-Stars $\left(\right.$ Allstar $_{i t}=0.075$, p-value $\left.<0.05\right)$. This supports prior findings regarding All-Star analysts' access to private information (Mayew 2008; Mayew et al. 2013). The likelihood of issuing a bold earnings forecast is not affected by brokerage size $\left(\right.$ Broker_Size_std $d_{i j t}=-0.002$, p-value $\left.>0.10\right)$. Finally, analysts are less likely to issue bold earnings forecasts for larger firms $\left(A T \_s t d_{i j t}=-0.134, \mathrm{p}\right.$-value $<$ 0.01), but they are more likely to issue bold earnings forecasts for firms with greater business press coverage $\left(N e w s \_s t d_{i j t}=0.263\right.$, p-value $\left.<0.01\right)$ and share turnover (Turnover_st $d_{i j t}=0.096, \mathrm{p}$-value $\left.<0.01\right)$.

\footnotetext{
${ }^{17}$ The Pearson goodness-of-fit test suggests reasonable model fit ( $\mathrm{p}$-value $>0.10$ ).
} 
My second hypothesis predicts a positive association between earnings forecast accuracy and institutional ownership. I report the estimation of Equation (2) in Table 3, Column 2. Consistent with $\mathrm{H} 2$, analysts issue more accurate earnings forecasts for firms with greater institutional ownership $\left(\right.$ Inst_Inv $_{i j t}$ coefficient $=0.021$, p-value $\left.<0.01\right) .^{18}$ This result provides evidence that ownership by valued clients, on average, motivates analysts to issue more accurate earnings forecasts. This result suggests that the information demands of important clients lead analysts to place a higher priority on firms with greater institutional ownership and report more accurate forecasts. Furthermore, the empirical relation between institutional ownership and earnings forecast accuracy supports survey evidence that client demand for information motivates analysts to forecast accurately (Brown et al. 2015).

The control variables are generally consistent with prior studies. In my study, I find that bold forecasts are less accurate $\left(\right.$ Bold $_{i j t}$ coefficient $=-0.051$, $\mathrm{p}$-value $\left.<0.01\right)$. This differs from findings in Clement and Tse (2005) because of the method used to measure a bold earnings forecast. ${ }^{19}$ In addition, analysts with outstanding optimistic stock recommendations do not issue more accurate earnings forecasts $(0.002, \mathrm{p}$-value $>$ 0.10). This suggests that certain strategic behaviors may not lead to more accurate earnings forecasts. Furthermore, brokerage size is not significantly associated with

\footnotetext{
${ }^{18}$ This result is robust using two-digit SIC fixed effects instead of GICS industry fixed effects.

${ }^{19}$ In untabulated results, I estimate Equation (2) using the Clement and Tse (2005) measure of boldness, and the positive association between institutional ownership and earnings forecast accuracy remains. Further, I find boldness, as measured by Clement and Tse, is positively associated with earnings forecast accuracy (coefficient $=0.043$, p-value $<0.01$ ), which is consistent with their findings.
} 
earnings forecast accuracy. The $R^{2}$ is 1.9 percent, which is consistent with recent studies examining earnings forecast accuracy (Bae et al. 2008; Lehavy, Li, and Merkley 2010).

\subsubsection{Institutional Investor Type}

Prior research suggests that some institutions rely on private information more than others. As a result, I hypothesize that analysts are more likely to issue bold earnings forecasts for firms with greater ownership by institutions that rely on private information to determine investments and issue more accurate earnings forecasts for firms with greater ownership by other institutions. Table 4, Panel A reports the estimates of Equation (1) with variables representing the ownership by various types of institutions. For instance, Column 1 reports the estimates of Equation (1) using variables for ownership by transient and non-transient institutions. I generally find that analysts are no more likely to issue bold earnings forecasts for firms with greater ownership by institutions that likely rely on private information. However, consistent with my expectations, analysts are more likely to issue bold earnings forecasts for firms with greater ownership by investment advisor institutions with transient investments $\left(I A \_T r a n s \_I n s t \_I n v \_s t d_{i j t}=0.073, \mathrm{p}\right.$-value $\left.<0.10\right)$. Analysts are approximately 7.6 percent more likely to issue a bold earnings forecast for the firm they follow with the greatest ownership by investment advisors institutions with transient investments relative to the firm with the lowest.

Table 4, Panel B reports the estimates of Equation (2) with the variables representing the ownership by various types of institutions. H3b hypothesizes that analysts will issue more accurate earnings forecasts for firms with greater ownership by 
institutions that are not known to rely on private information. Consistent with my expectations, I find that analysts issue more accurate earnings forecasts for firms with greater ownership by non-growth institutions (Non_Growth_Inst_Inv_std $d_{i j t}=0.017, \mathrm{p}-$ value $<0.05)$ and by non-investment advisor institutions $\left(N o n \_I A \_I n s t \_I n v \_s t d_{i j t}=\right.$ 0.017 , p-value < 0.10). These results provide some evidence that analysts seek to provide accurate earnings forecasts for firms that do not rely on private information to determine investments.

Contrary to my expectations, I do not find that analysts issue more accurate forecasts for firms with greater ownership by non-transient institutions and institutions that are not investment advisor institutions with transient investments. However, I find that analysts issue more accurate earnings forecasts for firms with greater ownership by transient institutions $\left(\right.$ Trans_Inst_Inv_std $d_{i j t}=0.021, \mathrm{p}$-value $\left.=0.01\right)$ and greater ownership by investment advisor institutions with transient investment strategies $\left(I A \_T r a n s \_I n s t \_I n v \_s t d_{i j t}=0.020, \mathrm{p}\right.$-value $\left.<0.05\right)$. Although transient institutions and investment advisor institutions with transient investment strategies may use private information to determine investments, these results may suggest that certain institutions demand accurate forecasts regardless of their need for private information. The results in Table 4, although not fully consistent with my expectations, provide evidence that institutional investors are not a homogenous group of investors, and the different types of institutions demand different types of information from analysts. This is consistent with findings in prior literature that investigates differences across institutional investor types. 


\section{ADDITIONAL ANALYSES}

\subsection{Optimistically Bold Forecasts}

The boldness definition used in this study allows for optimistic and pessimistic forecasts to be defined as bold forecasts. Although bold forecasts can signal private information regardless of whether the forecast is above or below the consensus, optimistic and pessimistic forecasts may have different consequences to the analyst. Optimistic forecasts increase trading volume and revenue for the analyst's employer (Cowen, Groysberg, and Healy 2006). Further, analysts face the possibility of losing access to management when their earnings forecast is significantly below the consensus, and analysts and analysts' clients value access to management teams (Brown et al. 2015). For these reasons, I expect analysts to issue optimistically bold earnings forecasts for firms with greater institutional ownership and greater ownership by institutions that rely on private information.

However, analysts may also decide to issue a pessimistically bold earnings forecast. Analysts potentially lose access to management following the issuance of an unfavorable forecast (Brown et al. 2015); however, analysts may ignore the risk of losing access to management when their information is accurate. Furthermore, management prefers beatable earnings targets and attempt to "walk-down" analysts to a manageable earnings target (Richardson, Teoh, and Wysocki 2004; Ke and Yu 2006). As a result, analysts may prefer to issue a pessimistically bold earnings forecast to provide firm managers with beatable targets. 
Table 5 provides the estimation of Equation 1 modified to estimate the likelihood of an optimistically bold earnings forecast, where an optimistically bold earnings forecast is a bold forecast that is greater than the consensus. Analysts are more likely to issue an optimistically bold earnings forecast for firms with greater institutional ownership. Analysts are approximately 9.5\% more likely to issue a bold earnings forecast for the firm in their portfolio with the greatest institutional ownership relative to the firm with the lowest institutional ownership. Analysts are also more likely to issue an optimistically bold earnings forecast for firms with greater ownership by institutions that likely rely on private information. Analysts are more likely to issue an optimistically bold earnings forecast for firms with greater ownership by transient institutions, investment advisor institutions, and investment advisor institutions with transient investments. These findings may suggest that analysts fulfill the private information demands of their clients, especially when the private information is positive. Furthermore, analysts are less likely to issue pessimistically bold forecasts for firms with greater institutional ownership and ownership by institutions prioritizing private information.

In untabulated results, I estimate Equation (2) modified to include an indicator variable for optimistically bold forecasts as a control variable. The associations between institutional ownership and earnings forecast accuracy are consistent with those in Table 3 and 4. However, I find that optimistically bold earnings forecasts are more accurate (pvalue < 0.01). Further, I find pessimistically bold earnings forecasts are less accurate. 
These findings may suggest that optimistically bold earnings forecasts within 90 days of the earnings announcement are credible signals of expected firm performance.

\subsection{Leader-Follower Analysts}

Another way an analyst can introduce private information to clients is to be the timeliest analyst, or a lead analyst. Cooper, Day, and Lewis (2001) identify lead analysts based on their earnings forecast timeliness, and they find that lead analysts influence stock prices more than less timely analysts. This suggests that lead analyst forecasts are more informative than the forecasts of other analysts. I test whether analysts are timelier for firms with greater institutional ownership. I calculate the leader-follower ratio defined by Cooper et al. (2001) and Loh and Stulz (2011), and I standardize this ratio across all firms the analyst follows during the year. I regress this standardized variable on firm characteristics.

I present the results of the leader-follower test in Table 6. I find that analysts are not timelier for firms with greater institutional ownership using my sample of earnings forecasts. ${ }^{20}$ This result, or lack thereof, may be driven by the sample used in my tests. I keep only the last earnings forecast issued by the analysts prior to the earnings announcement, and these forecasts might not be the timeliest forecasts issued by analysts during the year.

\subsection{Forecast Frequency}

Forecast frequency is commonly used as a measure of analyst effort (e.g., Jacob et al. 1999). Although forecast boldness and accuracy are important properties of

\footnotetext{
${ }^{20}$ The sample size is smaller than the other tests due to missing leader-follower ratio values.
} 
earnings forecasts, they do not necessarily represent the amount of time and effort the analyst expended on research activities. As a result, I examine whether analysts forecast more frequently for firms they follow with greater institutional ownership. I determine the number of forecasts issued by each analyst for each firm they followed, and I transform earnings forecast frequency across the firms the analyst followed during the year. I report the results of the forecast frequency test in Table 7

Regressing forecast frequency on firm characteristics, I generally find no association between forecast frequency and institutional ownership, but analysts issue fewer forecasts for firms with greater ownership by institutions specializing in growth firms. Analysts do, however, forecast more frequently for larger firms (based on total assets), and firms with greater business press and analyst coverage. The results of Table 7 suggest analysts exert greater effort on some firms based on their characteristics; however, I do not find that analysts exert greater effort for firms with greater institutional ownership.

\subsection{Cross-Sectional Tests}

Studies in decision making suggest that opportunity costs are important factors in decision making when individuals face constraints (Payne et al. 1988; Payne et al. 1996; Rieskamp and Hoffrage 2008); therefore, analyst earnings forecast properties should reflect the incentives associated with institutional ownership, especially when resources are constrained. I expand Equations (1) and (2) to include variables that interact the institutional ownership variables and the analyst and brokerage characteristics associated 
with resource constraints. I use the standardized firms followed, industries followed, and brokerage size to represent resource constraints.

I present the estimates of Equation (1) with interaction terms in Table 8, Panel A. ${ }^{21}$ I find that analysts are no more likely to issue bold earnings forecasts for firms with greater institutional ownership (Inst_Inv $v_{i j t}=0.004$, p-value $\left.>0.10\right)$, but they are more likely to issue a bold earnings forecast for firms with greater ownership by investment advisor institutions $\left(I A \_I n s t \_I n v \_s t d_{i j t}=0.043\right.$, p-value $\left.<0.10\right)$. However, I do not find an association between earnings forecast boldness and institutional ownership when resources are constrained.

In Table 8, Panel B, I report the estimates of Equation (1) modified to estimate the likelihood of an optimistically bold earnings forecast. I find analysts are more likely to issue a bold earnings forecast for firms that have greater ownership by institutions that require private information, specifically transient institutions, investment advisor institutions, and investment advisor institutions with transient investments. Further, I find some evidence that analysts following a greater number of firms are more likely to issue an optimistically bold earnings forecast for firms with greater ownership by transient institutions, investment advisor institutions with transient investments, and institutions specializing in value firms.

Panel C provides the estimates of Equation (2) with interaction terms. Consistent with Table 4, I find analysts issue more accurate earnings forecasts for firms with greater

\footnotetext{
${ }^{21} \mathrm{Ai}$ and Norton (2003) find the sign and standard errors of interactions terms are unreliable for non-linear models. As a result, I use an OLS regression to estimate Equation (1).
} 
institutional ownership. Additionally, I find that some resource constraints affect the relationship between earnings forecast accuracy and institutional ownership. Analysts following firms in a greater number of sectors issue more accurate earnings forecasts for firms with greater ownership by transient institutions and investment advisor institutions with transient investments. Further, I find analysts employed at smaller brokerages issue more accurate earnings forecasts for firms with greater ownership by transient institutions, investment advisor institutions with transient investments, and institutions investing in value firms. The findings in Table 7 provide some evidence that resource constraints influence analyst decisions.

\subsection{Firm-Level Institutional Ownership}

In this study, I transform institutional ownership variables across the firms an analyst follows. However, the presence of institutional investors may motivate an analyst to issue bold or accurate forecasts regardless of the institutional ownership of the other firms the analyst follows. I modify Equations (1) and (2) by including untransformed institutional ownership variables to determine if firm-level institutional ownership influences earnings forecast accuracy and boldness.

Table 9, Panel A reports the estimation of Equation (1). Consistent with Table 3, analysts are no more likely to issue bold earnings forecasts for firms with greater firmlevel institutional ownership. Additionally, the results for the transformed institutional ownership variables are generally consistent with Table 4, Panel A. I also find that analysts are more likely to issue bold earnings forecasts for firms with greater transient institutional ownership relative to the other firms the analyst follows 
$\left(T r a n s \_I n s t \_I n v \_s t d_{i j t}=0.098, \mathrm{p}\right.$-value $\left.<0.10\right)$, but analysts are less likely to issue bold earnings forecasts for firms with greater firm-level transient institutional ownership $\left(\right.$ Trans_Inst_Inv $v_{i j t}=-0.015, \mathrm{p}$-value $\left.<0.05\right)$. The sum of these coefficients are significantly greater than zero (p-value $<0.10)$. This suggests that the overall effect of ownership by transient institutions is positively associated with earnings forecast boldness.

Panel B reports the estimation of Equation (1) modified for optimistically bold earnings forecasts. The transformed institutional ownership variable coefficients are consistent with Table 5. I also find that analysts are more likely to issue optimistically bold earnings forecasts for firms with greater firm-level ownership by transient institutions and investment advisor institutions with transient investments. Finally, Panel C reports the estimation of Equation (2). Again, evidence consistent with Table 4, Panel B. These results suggest that institutional ownership relative to the other firms an analyst follows is an important determinant to earnings forecast properties after controlling for firm-level institutional ownership and provides some evidence that analysts consider the opportunity costs of allocating resource to each of the firms they cover.

\subsection{Blockholder Investors}

A key assumption in my analyses is that all institutional investors use sell-side analysts as a source of information. However, investors may receive access to management and private firm information when they own a significant portion of the firm. The large blockholder stake in the firm creates an incentive to closely monitor the firm (Edmans 2009), and their large investment can potentially give the blockholder 
direct access to management for information about the firm through the threat of exit (Parrino, Sias, Starks 2003; McCahery, Sautner, and Starks 2010). As a result, blockholder investors do not need sell-side analysts to obtain pertinent firm information.

To examine the potential confound of blockholders on my main analysis, I create variables for institutional ownership without blockholder investors. ${ }^{22}$ I scale the number of non-blockholder institutional investors by the number of analysts following the firm, and transform this ratio across the firms the analyst follows.

Table 10 reports the estimates of Equations (1) and (2) after removing blockholder institutional investors from the institutional investor variables. The results are consistent with the findings in Tables 3, 4, and 5. Analysts are no more likely to issue bold earnings forecasts for firms with greater institutional ownership regardless of the type of institution. However, analysts are more likely to issue an optimistically bold earnings forecast for firms with greater institutional ownership, and greater ownership by transient institutions, investment advisor institutions, and investment advisor institutions with transient investments. With respect to earnings forecast accuracy, analysts issue more accurate earnings forecasts for firms with greater institutional ownership after removing blockholder investors.

\footnotetext{
${ }^{22}$ I define a blockholder investor as an investor that owns at least $5 \%$ of the shares outstanding.
} 


\section{CONCLUSION}

The purpose of this study is to determine how analyst incentives affect analyst earnings forecasts. I examine whether characteristics of the firms an analyst follows explain differences in earnings forecast properties. Specifically, I analyze the demand for analyst information by using the number of institutional investors as a measure for demand. Institutional investors are analysts' most important clients, and analysts are motivated to fulfill the information demands of their clients (Brown et al. 2015). I evaluate whether the demand for information from analyst clients influences analysts to issue bold or more accurate earnings forecasts.

I find that analysts are no more likely to issue bold earnings forecasts for firms with greater institutional ownership relative to other firms they follow, but analysts issue more accurate earnings forecasts for firms with greater institutional ownership. I also find some evidence that analysts are more likely to issue bold forecasts for firms with greater ownership by institutions that rely on private information to make informed investment decisions. Additionally, I find that analysts issue more accurate forecasts for firms with greater ownership by certain institution types. For instance, analysts issue more accurate forecasts for firms they follow with greater ownership by institutions with transient investments, non-investment advisor institutions, and institutions that specialize on value firms. Although institutional investors are important analyst clients and sophisticated investors, institutions defer in investment strategies and fiduciary 
restrictions. As such, my findings provide evidence that analysts behave differently based on the type of institutions with ownership in the firms the analysts cover.

The findings in this study provide evidence that analysts focus on certain firms in order to fulfill the information needs of their clients. Importantly, my study provides evidence that analyst decision making is affected by the opportunity costs associated with each firm an analyst follows, and analysts may prioritize the firms within their portfolio. My study provides important contributions to the literature by examining the inputs to the analyst reporting environment and how analysts behave due to resource constraints and incentives. 


\section{REFERENCES}

Abarbanell, J.S., B.J. Bushee, and J.S. Raedy. 2003. Institutional investor preferences and price pressure: The case of corporate spin-offs. Journal of Business 78(2): 233-261.

Ai, C., and E. C. Norton. 2003. Interaction terms in logit and probit models. Economic Letters 80(1): 123-129.

Bae, K.H., R. M. Stulz, and H. Tan. 2008. Do local analysts know more? A crosscountry study of the performance of local analysts and foreign analysts. Journal of Financial Economics 88: 581-606.

Barniv, R., O.K. Hope, M.J. Myring, and W.B. Thomas. 2009. Do analysts practice what they preach and should investors listen? Effects of recent regulations. The Accounting Review 84(4): 1015-1039.

Becker, G.S. 1965. A theory of the allocation of time. The Economic Journal 75(299): 493-517.

Beyer, A., D.A. Cohen, T.Z. Lys, and B.R. Walther. 2010. The financial reporting environment: Review of recent literature. Journal of Accounting and Economics 50(2-3): 296-343.

Bhojraj, S., C. Lee, and D. Oler. 2003. What's my line? A comparison of industry classification schemes for capital market research. Journal of Accounting Research 41: 745-774.

Boni, L., and K.L. Womack. 2006. Analysts, industries, and price momentum. Journal of Financial and Quantitative Analysis 41(1): 85-109.

Bound, J., D.A. Jaeger, and R.M. Baker. 1995. Problems with instrumental variables estimation when the correlation between the instruments and the endogenous explanatory variable is weak. Journal of the American Statistical Association 90(430): 443-450.

Bradshaw, M.T. 2011. Analysts' forecasts: What do we know after decades of work? Working paper: Boston College.

Brown, L.D. 1993. Earnings forecasting research: Its implications for capital markets research. International Journal of Forecasting 9(3): 295-320.

Brown, L.D., A.C. Call, M.B. Clement, N.Y. Sharp. 2014. Toward a greater understanding of buy-side analysts. Working Paper: Temple University, Arizona State University, University of Texas at Austin, Texas A\&M University. 
Brown, L.D., A.C. Call, M.B. Clement, N.Y. Sharp. 2015. Inside the "black box" of sellside financial analysts. Journal of Accounting Research 53(1): 1-47.

Bushee, B.J. 1998. The influence of institutional investors on myopic R\&D investment behavior. The Accounting Review 73(3): 305-333.

Bushee, B.J. 2001. Do institutional investors prefer near-term earnings over long-run value? Contemporary Accounting Research 18(2): 207-246.

Bushee, B.J., and T.H. Goodman. 2007. Which institutional investors trade based on private information about earnings and returns? Journal of Accounting Research 45(2): 289-321.

Chen, S. and D.A. Matsumoto. 2006. Favorable versus unfavorable recommendations: The impact on analyst access to management-provided information. Journal of Accounting Research 44(4): 657-689.

Clement, M.B. 1999. Analyst forecast accuracy: Do ability, resources, and portfolio complexity matter? Journal of Accounting and Economics 27: 285-303.

Clement, M.B. and S.Y. Tse. 2003. Do investors respond to analysts' forecast revisions as if forecast accuracy is all that matters? The Accounting Review 78(1): 227-249.

Clement, M.B. and S.Y. Tse. 2005. Financial analyst characteristics and herding behavior in forecasting. The Journal of Finance 60(1): 307-341.

Cooper, R.A., T.E. Day, and C.M. Lewis. 2001. Following the leader: A study of individual analysts' earnings forecasts. Journal of Financial Economics 61(3): 383-416.

Cowen, A., B. Broysberg, and P. Healy. 2006. Which types of analyst firms are more optimistic? Journal of Accounting and Economics 41(1-2): 119-146.

Drake, M.S., L. Rees, and E.P. Swanson. 2011. Should investors follow the prophets or the bears? Evidence on the use of public information by analysts and short sellers. The Accounting Review 101-130.

Edmans, A. 2009. Blockholder trading, market efficiency, and managerial myopia. The Journal of Finance 64(6): 2481-2513.

Fried, D., and D. Givoly. 1982. Financial analysts' forecasts of earnings: A better surrogate for market expectations. Journal of Accounting and Economics 4(2): 85-107.

Green, T.C., R. Jame, S. Markov, and M. Subasi. 2014. Access to management and the informativeness of analyst research. Journal of Financial Economics 114(2): 239-255. 
Holt, C. A., and S. K. Laury. 2002. Risk aversion and incentive effects. American Economic Review 92(5): 1644-1655.

Hong, H., J.D. Kubik, and A. Solomon. 2000. Security analysts' career concerns and herding of earnings forecasts. The RAND Journal of Economics 31(1): 121-144.

Hong, H. and J.D. Kubik. 2003. Analyzing the analysts: Career concerns and biased earnings forecasts. The Journal of Finance 58(1): 313-351.

Hui, K.W. and P.E. Yeung. 2012. Underreaction to industry-wide earnings and the postforecast revision drift. Journal of Accounting Research 51: 701-737.

Hutton, A.P., L.F. Lee, and S.Z. Shu. 2012. Do managers always know better? The relative accuracy of management and analyst forecasts. Journal of Accounting Research 50(5): 1217-1244.

Jacob, J., T.Z. Lys, and M.A. Neale. 1999. Expertise in forecasting performance of security analysts. Journal of Accounting and Economics 28: 27-50.

Kachelmeier, S. J. and M. Shehata. 1992. Examining risk preferences under high monetary incentives: Experimental evidence from the People's Republic of China. American Economic Review 82(5): 1120-41.

Kadan, O., L. Madureira, R. Wang, and T. Zach. 2012. Analysts' industry expertise. Journal of Accounting and Economics 54(2-3): 95-120.

Ke, B., and K. Petroni. 2004. How informed are actively trading institutional investors? Evidence from their trading behavior before a break in a string of consecutive earnings increases. Journal of Accounting Research 42(5): 895-927.

Ke, B., and Y. Yu. 2006. The effect of issuing biased earnings forecasts on analysts' access to management and survival. Journal of Accounting Research 44(5): 965999.

Lang, M.H., and R.J. Lundholm. 1996. Corporate disclosure policy and analyst behavior. The Accounting Review 71(4): 467-492.

Lang, M.H., and M. McNichols. 1997. Institutional trading and corporate performance. Working paper, Stanford University.

Lehavy, R., F. Li, and K. Merkley. 2011. The effect of annual report readability on analyst following and the properties of their earnings forecasts. The Accounting Review 86(3): 1087-1115.

Lim, T. 2001. Rationality and analysts' forecast bias. The Journal of Finance 66(1): 369385. 
Loh, R.K, and R.M. Stulz. 2011. When are analyst recommendation changes influential? The Review of Financial Studies 24(2): 593-627.

Maber, D.A., B. Groysberg, and P.M. Healy. 2014. The use of broker votes to reward brokerage firms' and their analysts' research activities. Working paper: University of Michigan, Harvard Business School.

Mayew, W.J. 2008. Evidence of management discrimination among analysts during earnings conference calls. Journal of Accounting Research 46(3): 627-659.

Mayew, W.J., N.Y. Sharp, and M. Venkatachalam. 2013. Using earnings conference calls to identify analysts with superior private information. Review of Accounting Studies 18: 386-413.

McCahery, J., Z. Sautner, and L. Starks. 2010. Behind the scenes: The corporate governance preferences of institutional investors. Working paper: Tilburg University, University of Amsterdam, and University of Texas at Austin.

Mikhail, M.B., B.R. Walther, and R.H. Willis. 1997. Do security analysts improve their performance with experience? Journal of Accounting Research 35: 131-166.

O’Brien, P.C. 1988. Analysts' forecasts as earnings expectations. Journal of Accounting and Economics 10(1): 53-83.

O’Brien, P.C., and R. Bhushan. 1990. Analysts following and institutional ownership. Journal of Accounting Research 28: 55-76.

Parrino, R., R. Sias, L. Starks. 2003. Voting with their feet: Institutional ownership changes around forced CEO turnover. Journal of Financial Economics 68: 3-46.

Payne, J.W., J.R. Bettman, and E.J. Johnson. 1988. Adaptive strategy selection in decision making. Journal of Experimental Psychology 14(3): 534-552.

Payne, J.W., J.R. Bettman, and M.F. Luce. 1996. When time is money: Decision behavior under opportunity-cost time pressure. Organizational Behavior and Human Decision Processes 66(2): 131-152.

Porter, M. 1992. Capital choices: Changing the way America invests in industry. Boston: Council on Competitiveness/Harvard Business School.

Ramnath, S. 2002. Investor and analyst reactions to earnings announcements of related firms: An empirical analysis. Journal of Accounting Research 40(5): 1351-1376.

Ramnath, S., S. Rock, and P. Shane. 2008. The financial analyst forecasting literature: A taxonomy with suggestions for future research. International Journal of Forecasting 24(1): 34-75. 
Rees, L., N.Y. Sharp, and P.A. Wong. 2014. Working on the weekend: Do analysts strategically time the release of their recommendation revisions. Working paper: Texas A\&M University.

Richardson, S., S.H. Teoh, and P.D. Wysocki. 2004. The walk-down to beatable analyst forecasts: The role of equity issuance and insider trading incentives. Contemporary Accounting Research 21(4): 885-924.

Rieskamp, J. and U. Hoffrage. 2008. Inferences under time pressure: How opportunity costs affect strategy selection. Acta Psychologica 127: 258-276.

Shipper, K. 1991. Analysts' forecasts. Accounting Horizons 5: 105-21.

Solomon, D.H., and E.F. Soltes. 2015. What are we meeting for? The consequences of private meetings with investors. Journal of Law and Economics (forthcoming).

Stickel, S.E. 1992. Reputation and performance among security analysts. The Journal of Finance 47: 1811-1836.

Stickel, S.E. 1995. The anatomy of the performance of buy and sell recommendations. Financial Analyst Journal 51(5): 25-39.

Trueman, B. 1994. Analyst forecasts and herding behavior. The Review of Financial Studies 7: 97-124.

U.S. Securities and Exchange Commission. "Form 13F - Reports Filed by Institutional Investment Managers." 2014. Available at: http://www.sec.gov/answers/form13f.htm.

Welch. I. 2000. Herding among security analysts. Journal of Financial Economics 53(3): 369-396. 


\section{APPENDIX A}

\section{VARIABLE DEFINITIONS}

\begin{tabular}{|c|c|}
\hline Variable & Definition \\
\hline \multicolumn{2}{|c|}{ Institutional Investor variables } \\
\hline Growth_Inst_Inv $v_{j t}$ & $\begin{array}{l}\text { is equal to the number of institutional owners of } \\
\text { the firm that specialize in growth firms scaled by } \\
\text { the number of analysts following the firm. }\end{array}$ \\
\hline Growth_Inst_Inv_std ${ }_{i j t}$ & $\begin{array}{l}\text { is equal to Growth_Inst_Inv } v_{j t} \text { standardized across } \\
\text { the firms the analyst follows during the year. }\end{array}$ \\
\hline$I A \_I n s t \_I n v_{j t}$ & $\begin{array}{l}\text { is equal to the number of investment advisor } \\
\text { institutional owners of the firm scaled by the } \\
\text { number of analysts following the firm. }\end{array}$ \\
\hline$I A \_I n s t \_I n v \_s t d_{i j t}$ & $\begin{array}{l}\text { is equal to IA_Inst_Inv } v_{j t} \text { standardized across the } \\
\text { firms the analyst follows during the year. }\end{array}$ \\
\hline$I A \_T r a n s \_I n s t \_I n v_{j t}$ & $\begin{array}{l}\text { is equal to the number of investment advisor } \\
\text { institutional owners of the firm with transient } \\
\text { investments scaled by the number of analysts } \\
\text { following the firm. }\end{array}$ \\
\hline IA_Trans_Inst_Inv_std ${ }_{i j t}$ & $\begin{array}{l}\text { is equal to IA_Trans_Inst_Inv } v_{j t} \text { standardized across } \\
\text { the firms the analyst follows during the year. }\end{array}$ \\
\hline Inst_Inv $v_{j t}$ & $\begin{array}{l}\text { is equal to the number of institutional owners of } \\
\text { the firm scaled by the number of analysts } \\
\text { following the firm. }\end{array}$ \\
\hline Inst_Inv_std ${ }_{i j t}$ & $\begin{array}{l}\text { is equal to Inst_Inv } v_{i j t} \text { standardized across the firms } \\
\text { the analyst follows during the year. }\end{array}$ \\
\hline Non_Growth_Inst_Inv $v_{j t}$ & $\begin{array}{l}\text { is equal to the number of institutional owners of } \\
\text { the firm that do not specialize in growth firms } \\
\text { scaled by the number of analysts following the } \\
\text { firm. }\end{array}$ \\
\hline Non_Growth_Inst_Inv_std $i j t$ & $\begin{array}{l}\text { is equal to Non_Growth_Inst_Inv } v_{j t} \text { standardized } \\
\text { across the firms the analyst follows during the } \\
\text { year. }\end{array}$ \\
\hline Non_IA_Inst_Inv $v_{j t}$ & $\begin{array}{l}\text { is equal to the number of non-investment advisor } \\
\text { institutional owners of the firm scaled by the } \\
\text { number of analysts following the firm. }\end{array}$ \\
\hline
\end{tabular}

(continued on next page) 


\section{VARIABLE DEFINITIONS (continued)}

\begin{tabular}{|c|c|}
\hline Variable & Definition \\
\hline Non_IA_Inst_Inv_std ${ }_{i j t}$ & $\begin{array}{l}\text { is equal to Non_IA_Inst_Inv } v_{j t} \text { standardized across } \\
\text { the firms the analyst follows during the year. }\end{array}$ \\
\hline Non_IA_Trans_Inst_Inv $v_{j t}$ & $\begin{array}{l}\text { is equal to the number of institutional owners of } \\
\text { the firm that are not investment advisors with } \\
\text { transient investments scaled by the number of } \\
\text { analysts following the firm. }\end{array}$ \\
\hline Non_IA_Trans_Inst_Inv_std ${ }_{i j t}$ & $\begin{array}{l}\text { is equal to Non_IA_Trans_Inst_Inv } v_{j t} \text { standardized } \\
\text { across the firms the analyst follows during the } \\
\text { year. }\end{array}$ \\
\hline Non_Trans_Inst_Inv $v_{j t}$ & $\begin{array}{l}\text { is equal to the number of institutional owners of } \\
\text { the firm without transient investments scaled by } \\
\text { the number of analysts following the firm. }\end{array}$ \\
\hline Non_Trans_Inst_Inv_std $d_{i j t}$ & $\begin{array}{l}\text { is equal to Non_Trans_Inst_Inv } v_{j t} \text { standardized } \\
\text { across the firms the analyst follows during the } \\
\text { year. }\end{array}$ \\
\hline Non_Value_Inst_Inv $v_{j t}$ & $\begin{array}{l}\text { is equal to the number of institutional owners of } \\
\text { the firm that do not specialize in value firms scaled } \\
\text { by the number of analysts following the firm. }\end{array}$ \\
\hline Non_Value_Inst_Inv_std $i j t$ & $\begin{array}{l}\text { is equal to Non_Value_Inst_Inv } v_{j t} \text { standardized } \\
\text { across the firms the analyst follows during the } \\
\text { year. }\end{array}$ \\
\hline Trans_Inst_Inv $v_{j t}$ & $\begin{array}{l}\text { is equal to the number of institutional owners of } \\
\text { the firm with transient investments scaled by the } \\
\text { number of analysts following the firm. }\end{array}$ \\
\hline Trans_Inst_Inv_std $i j t$ & $\begin{array}{l}\text { is equal to Trans_Inst_In } v_{j t} \text { standardized across the } \\
\text { firms the analyst follows during the year. }\end{array}$ \\
\hline Value_Inst_Inv $v_{j t}$ & $\begin{array}{l}\text { is equal to the number of institutional owners of } \\
\text { the firm and specialize in value firms scaled by the } \\
\text { number of analysts following the firm. }\end{array}$ \\
\hline Value_Inst_Inv_std ${ }_{i j t}$ & $\begin{array}{l}\text { is equal to Value_Inst_Inv } v_{j t} \text { standardized across the } \\
\text { firms the analyst follows during the year. }\end{array}$ \\
\hline
\end{tabular}

\begin{tabular}{ll}
\hline Analyst Output Properties & \\
\hline Accuracy_std ${ }_{i j t}$ & $\begin{array}{l}\text { is the } A F E_{i j t} \text { value standardized across the analysts } \\
\text { following the firm during the year. }\end{array}$ \\
& is equal to the absolute value of the forecast error \\
& of the earnings forecast issued by the analyst for \\
& the firm during the year.
\end{tabular}

(continued on next page) 


\section{VARIABLE DEFINITIONS (continued)}

\begin{tabular}{|c|c|}
\hline Variable & Definition \\
\hline Bold $_{i j t}$ & $\begin{array}{l}\text { is a dichotomous variable equal to one if the } \\
\text { analyst revises his or her earnings forecast away } \\
\text { from the prior consensus and the forecast is more } \\
\text { than one standard deviation away from the } \\
\text { earnings forecast consensus prior to the forecast } \\
\text { announcement. }\end{array}$ \\
\hline Lag_Accuracy $_{i j t}$ & $\begin{array}{l}\text { is equal to the absolute forecast error of the } \\
\text { earnings forecast issued by the analyst for the firm } \\
\text { in the prior year standardized across the analysts } \\
\text { following the firm in the prior year. }\end{array}$ \\
\hline$L a g \_L F R_{i j t}$ & $\begin{array}{l}\text { is equal to the leader-follower ratio defined by } \\
\text { Cooper et al (2001) and Loh and Stulz (2011) } \\
\text { standardized across the firm the analyst follows } \\
\text { during the prior year. }\end{array}$ \\
\hline$L F R_{i j t}$ & $\begin{array}{l}\text { is equal to the leader-follower ratio defined by } \\
\text { Cooper et al. (2001) Loh and Stulz (2011) } \\
\text { standardized across the firm the analyst follows } \\
\text { during the year. }\end{array}$ \\
\hline Optimistic_Rec $c_{i j t}$ & $\begin{array}{l}\text { is a dichotomous variable equal to one if the } \\
\text { analyst's outstanding recommendation issued by } \\
\text { the analyst is more optimistic than the consensus } \\
\text { recommendation for the firm issued by other } \\
\text { analysts. }\end{array}$ \\
\hline Optimistic_Bold ${ }_{i j t}$ & $\begin{array}{l}\text { is a bold earnings forecast that is greater than the } \\
\text { consensus estimate. }\end{array}$ \\
\hline \multicolumn{2}{|c|}{ Analyst Characteristics } \\
\hline Allstar $_{i t}$ & $\begin{array}{l}\text { is a dichotomous variable equal to one if the } \\
\text { analyst received recognition as an Institutional } \\
\text { Investor All-American in the prior year. }\end{array}$ \\
\hline Brokerage_Size $_{i j t}$ & $\begin{array}{l}\text { is equal to the number of analysts issuing earnings } \\
\text { forecasts in the year for the brokerage employing } \\
\text { the analyst. }\end{array}$ \\
\hline Brokerage_Size_std ${ }_{i j t}$ & $\begin{array}{l}\text { is equal to Brokerage_Size } i j t \text { standardized across } \\
\text { the analysts following the firm during the year. }\end{array}$ \\
\hline Days_Elapsed $_{i j t}$ & $\begin{array}{l}\text { is equal to the number of days elapsed since the } \\
\text { last earnings forecast issued by any analyst } \\
\text { following the firm }\end{array}$ \\
\hline
\end{tabular}

(continued on next page) 


\section{VARIABLE DEFINITIONS (continued)}

\begin{tabular}{|c|c|}
\hline Variable & Definition \\
\hline Days_Elapsed_std ${ }_{i j t}$ & $\begin{array}{l}\text { is equal to Days_Elapsed }{ }_{i j t} \text { standardized across the } \\
\text { analysts following the firm during the year. }\end{array}$ \\
\hline Firm_Exp $p_{i j t}$ & $\begin{array}{l}\text { is equal to the number of years since the first } \\
\text { earnings forecast for the firm was issued by the } \\
\text { analyst. }\end{array}$ \\
\hline Firm_Exp_std ${ }_{i j t}$ & $\begin{array}{l}\text { is equal to Firm_Exp } p_{i j t} \text { standardized across the } \\
\text { analysts following the firm during the year. }\end{array}$ \\
\hline Follow $_{i j t}$ & $\begin{array}{l}\text { is equal to the number of firms the analyst follows } \\
\text { during the year. }\end{array}$ \\
\hline Follow_std ${ }_{i j t}$ & $\begin{array}{l}\text { is equal to Follow } w_{i j t} \text { standardized across the } \\
\text { analysts following the firm during the year. }\end{array}$ \\
\hline Forecast_Freq $_{i j t}$ & $\begin{array}{l}\text { is equal to the number of earnings forecasts issued } \\
\text { by the analyst for the firm during the year. }\end{array}$ \\
\hline Forecast_Freq_std $i j t$ & $\begin{array}{l}\text { is equal to Forecast_Freq } q_{i j t} \text { standardized across the } \\
\text { analysts following the firm during the year. }\end{array}$ \\
\hline Frequency_std $d_{i j t}$ & $\begin{array}{l}\text { is equal to Forecast_Freq } q_{i j t} \text { standardized across the } \\
\text { firms the analyst follows during the year. }\end{array}$ \\
\hline$G e n \_\operatorname{Exp}_{i j t}$ & $\begin{array}{l}\text { is equal to the number of years since the first } \\
\text { earnings forecast for any firm issued by the } \\
\text { analyst. }\end{array}$ \\
\hline$G_{e n \_E x p \_s t d} d_{i j t}$ & $\begin{array}{l}\text { is equal to General_Exp } \text { Ext }_{\text {standardized across the }} \text { staring the year. } \\
\text { analysts following the firm during the }\end{array}$ \\
\hline Horizon $_{i j t}$ & $\begin{array}{l}\text { is equal to the number of days from the issuance of } \\
\text { the forecast to the date of the earnings } \\
\text { announcement }\end{array}$ \\
\hline Horizon_std ${ }_{i j t}$ & $\begin{array}{l}\text { is equal to } \text { Horizon }_{i j t} \text { standardized across the } \\
\text { analysts following the firm during the year. }\end{array}$ \\
\hline Sectors $_{i j t}$ & $\begin{array}{l}\text { is equal the number of industries the analyst } \\
\text { follows during the year. Industries are determined } \\
\text { by GICS sector codes. }\end{array}$ \\
\hline Sectors_std ${ }_{i j t}$ & $\begin{array}{l}\text { is equal to Sectors } \text { Sijt }_{\text {standardized across the }} \\
\text { analysts following the firm during the year. }\end{array}$ \\
\hline Underwriter $_{i t}$ & $\begin{array}{l}\text { is an indicator variable equal to one if the } \\
\text { brokerage employing the analyst provides equity } \\
\text { or bond underwriting services. }\end{array}$ \\
\hline
\end{tabular}

(continued on next page) 


\section{VARIABLE DEFINITIONS (continued)}

\begin{tabular}{|c|c|}
\hline Variable & Definition \\
\hline \multicolumn{2}{|c|}{ Covered Firm Characteristics } \\
\hline$A T_{j t}$ & $\begin{array}{l}\text { is equal the firm's total assets reported in } \\
\text { Compustat. }\end{array}$ \\
\hline$A T \_s t d_{i j t}$ & $\begin{array}{l}\text { is equal to } A T_{j t} \text { standardize across the firms the } \\
\text { analyst follows during the year. }\end{array}$ \\
\hline Following $_{j t}$ & $\begin{array}{l}\text { is the number of analysts following the firm during } \\
\text { the year. }\end{array}$ \\
\hline Following_std $i j t$ & $\begin{array}{l}\text { is equal to Following } \text { Fit }_{\text {standardized across the }} \\
\text { firms the analyst follows during the year. }\end{array}$ \\
\hline Guidance $_{i j t}$ & $\begin{array}{l}\text { is dichotomous variable equal to one if the firm } \\
\text { issued management issued earnings guidance } \\
\text { within the } 30 \text { days prior to the earnings forecast } \\
\text { announcement. }\end{array}$ \\
\hline$I B_{j t}$ & $\begin{array}{l}\text { is equal to the firm's income before taxes reported } \\
\text { in Compustat. }\end{array}$ \\
\hline$I B \_s t d_{i j t}$ & $\begin{array}{l}\text { is equal to } I B_{j t} \text { standardized across the firms the } \\
\text { analyst follows during the year. }\end{array}$ \\
\hline$M V E_{j t}$ & $\begin{array}{l}\text { is equal to the firm's market value of equity at the } \\
\text { earnings announcement date. }\end{array}$ \\
\hline$M V E \_s t d_{i j t}$ & $\begin{array}{l}\text { Is equal to } M V E_{j t} \text { standardized across the firms the } \\
\text { analyst follows during the year. }\end{array}$ \\
\hline$N e w s_{j t}$ & $\begin{array}{l}\text { is equal to the number of unique news stories } \\
\text { captured by RavenPack Data Analytics for the } \\
\text { firm in the } 90 \text { days prior to the forecast } \\
\text { announcement. }\end{array}$ \\
\hline News_std $i j t$ & $\begin{array}{l}\text { is equal to } N e w s_{j t} \text { standardized across the firms the } \\
\text { analyst follows during the year. }\end{array}$ \\
\hline Spread $_{j t}$ & $\begin{array}{l}\text { is equal to the firm's bid-ask spread on the day the } \\
\text { earnings forecast was announced. }\end{array}$ \\
\hline Spread_std $d_{i j t}$ & $\begin{array}{l}\text { is equal to } \text { Spread }_{j t} \text { standardized across the firms } \\
\text { the analyst follows during the year. }\end{array}$ \\
\hline Turnover $_{j t}$ & $\begin{array}{l}\text { is equal to the firm's percentage of shares } \\
\text { outstanding traded on the day the earnings forecast } \\
\text { was announced. }\end{array}$ \\
\hline Turnover_std ${ }_{i j t}$ & $\begin{array}{l}\text { is equal to } \text { Turnover }_{j t} \text { standardized across the firms } \\
\text { the analyst follows during the year. }\end{array}$ \\
\hline
\end{tabular}




\section{APPENDIX B}

\section{FIGURES}

\section{FIGURE 1}

IBES Analyst 321 Forecast Accuracy

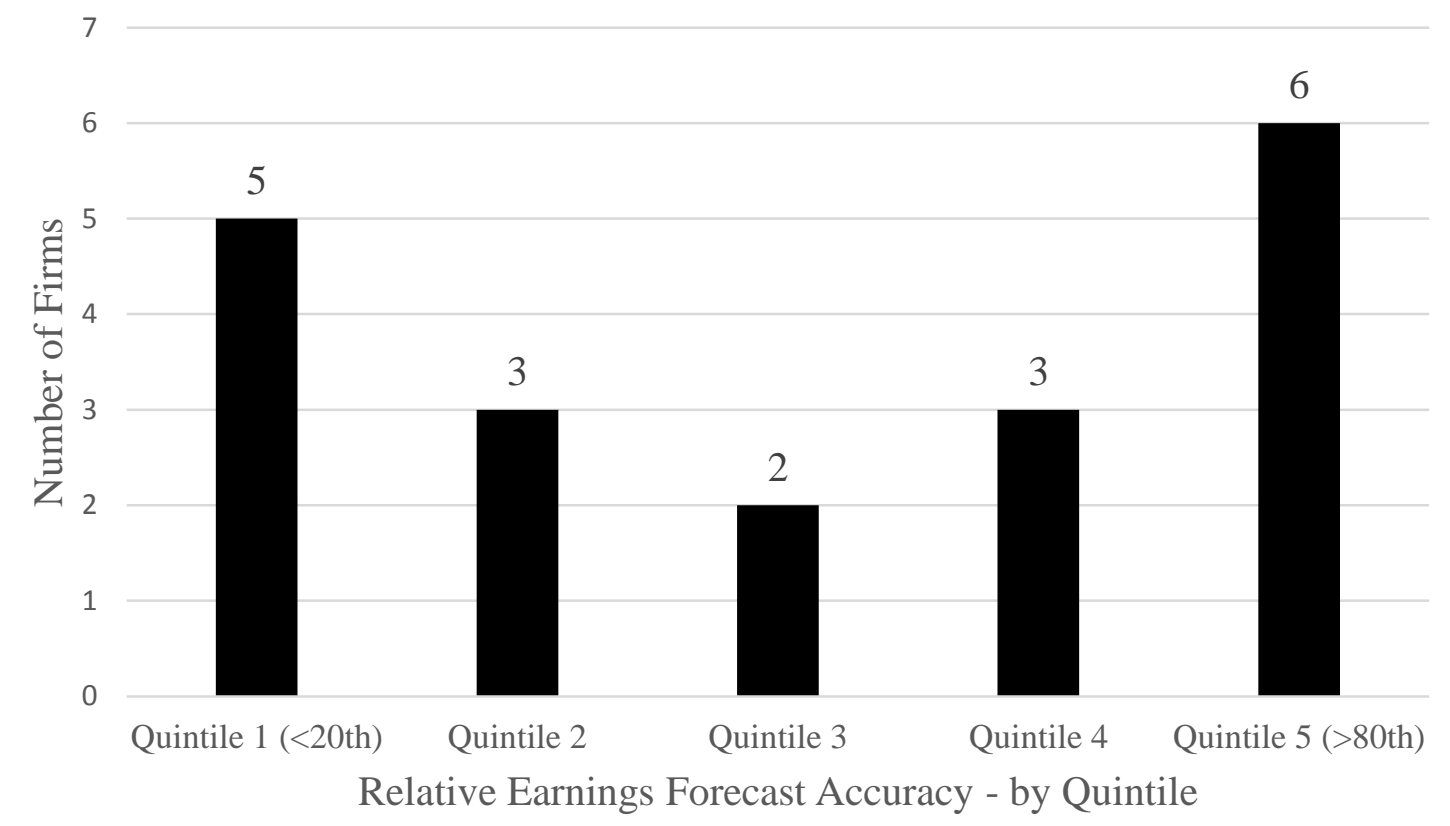


FIGURE 2

Institutional Owners of Firms Covered by IBES Analyst 321 in 2010

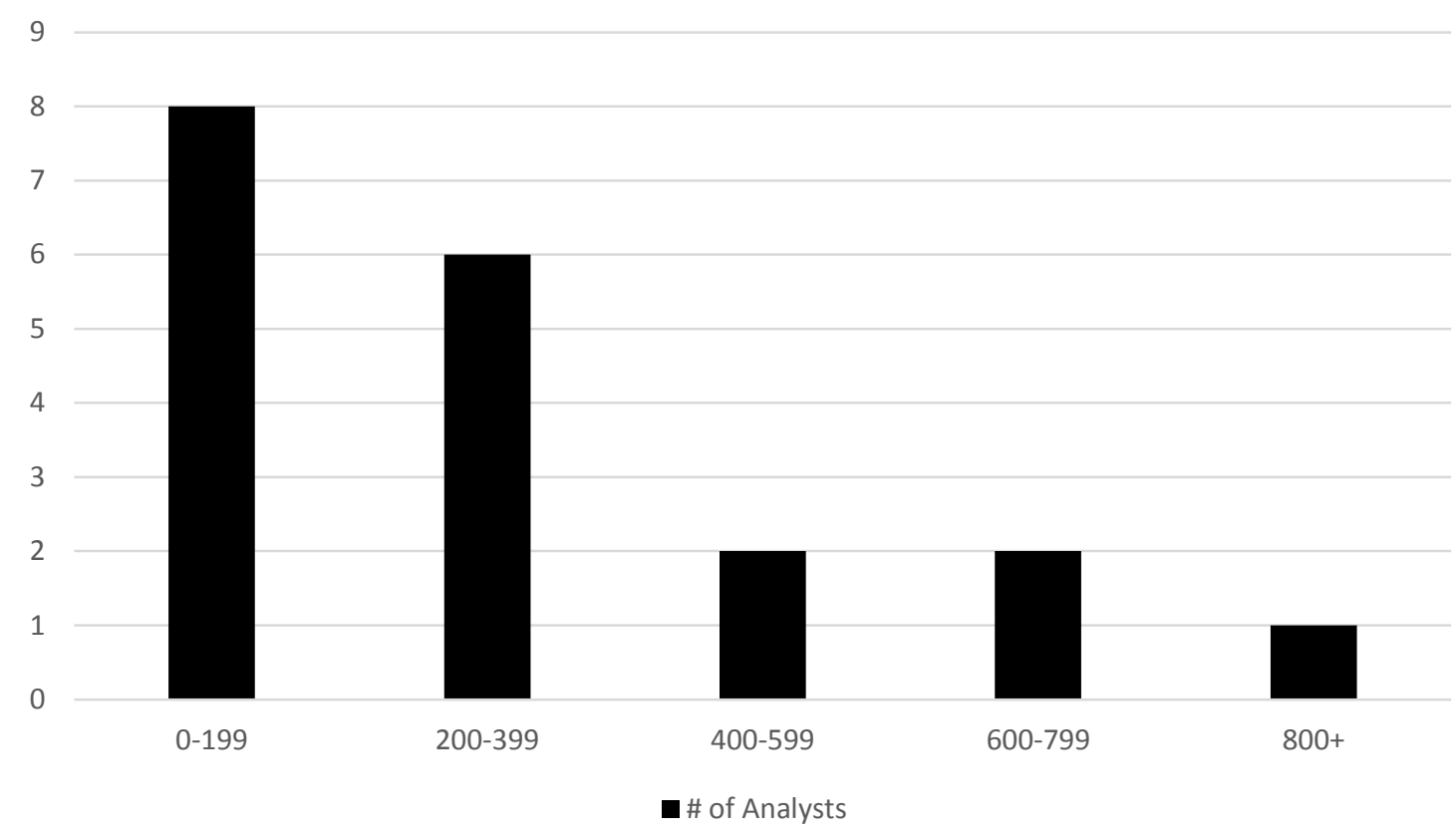




\section{APPENDIX C}

\section{TABLES}

TABLE 1

Descriptive Statistics and Correlations

Panel A: Raw Variable Descriptive Statistics

\begin{tabular}{|c|c|c|c|c|c|}
\hline Variable & Mean & $25^{\text {th }} \%$ & Median & $75^{\text {th }} \%$ & Std \\
\hline Bold & 0.28 & 0.00 & 0.00 & 1.00 & 0.45 \\
\hline Days_Elapsed & 11.73 & 1.00 & 4.00 & 15.00 & 16.90 \\
\hline Horizon & 44.17 & 20.00 & 41.00 & 69.00 & 28.22 \\
\hline Brokerage_Size & 63.58 & 19.00 & 45.00 & 98.00 & 59.42 \\
\hline Forecast_Freq & 2.89 & 2.00 & 3.00 & 4.00 & 1.70 \\
\hline Firm_Exp & 3.60 & 1.02 & 2.36 & 4.85 & 3.76 \\
\hline Gen_Exp & 7.49 & 3.14 & 6.09 & 10.27 & 5.77 \\
\hline Follow & 15.60 & 11.00 & 15.00 & 19.00 & 7.94 \\
\hline Sectors & 2.19 & 1.00 & 2.00 & 3.00 & 1.26 \\
\hline Analyst_Following & 9.35 & 4.00 & 8.00 & 13.00 & 6.47 \\
\hline Allstar & 0.15 & 0.00 & 0.00 & 0.00 & 0.35 \\
\hline Optimistic_Rec & 0.27 & 0.00 & 0.00 & 1.00 & 0.45 \\
\hline Underwriter & 0.79 & 0.00 & 1.00 & 1.00 & 0.40 \\
\hline Guidance & 0.21 & 0.00 & 0.00 & 0.00 & 0.40 \\
\hline$A T$ (in billions) & 30.31 & 1.06 & 3.60 & 14.06 & 140.00 \\
\hline$I B$ & 671.55 & 12.74 & 114.75 & 548.25 & $3,047.02$ \\
\hline Spread & 0.06 & 0.01 & 0.02 & 0.05 & 1.17 \\
\hline$M V E$ (in billions) & 13.00 & 0.90 & 2.80 & 10.26 & 33.46 \\
\hline Turnover & 0.27 & 0.13 & 0.22 & 0.35 & 0.23 \\
\hline News & 117.47 & 51.00 & 84.00 & 146.00 & 105.61 \\
\hline \multicolumn{6}{|c|}{ Panel B: Unstandardized Institutional Ownership Variable Descriptive Statistics } \\
\hline Inst_Inv & 17.40 & 9.96 & 14.50 & 21.74 & 11.27 \\
\hline Trans_Inst_Inv & 5.22 & 3.29 & 4.67 & 6.50 & 2.90 \\
\hline Non_Trans_Inst_Inv & 12.18 & 6.43 & 9.61 & 15.14 & 8.91 \\
\hline IA_Inst_Inv & 11.21 & 6.28 & 9.15 & 13.75 & 7.71 \\
\hline Non_IA_Inst_Inv & 6.19 & 3.53 & 5.29 & 7.96 & 3.85 \\
\hline IA_Trans_Inst_Inv & 4.56 & 2.87 & 4.07 & 5.64 & 2.53 \\
\hline Non_IA_Trans_Inst_Inv & 12.85 & 6.83 & 10.22 & 16.00 & 9.25 \\
\hline Growth_Inst_Inv & 3.59 & 1.35 & 2.48 & 4.64 & 3.48 \\
\hline Non_Growth_Inst_Inv & 13.82 & 7.70 & 11.58 & 17.48 & 9.02 \\
\hline Value_Inst_Inv & 5.63 & 2.89 & 4.60 & 7.20 & 3.03 \\
\hline Non_Value_Inst_Inv & 11.78 & 6.52 & 9.60 & 14.62 & 8.02 \\
\hline
\end{tabular}




\section{TABLE 1 (continued)}

Panel C: Transformed Accuracy and Control Variable Descriptive Statistics

\begin{tabular}{lccccc}
\hline & & & & & \\
Variable & Mean & $25^{\text {th }} \%$ & Median & $75^{\text {th }} \%$ & Std \\
\hline Accuracy_std & 0.60 & 0.22 & 0.71 & 1.00 & 0.39 \\
Lag_Accuracy_std & 0.58 & 0.20 & 0.67 & 1.00 & 0.39 \\
Days_Elapsed_std & 0.38 & 0.00 & 0.15 & 1.00 & 0.43 \\
Horizon_std & 0.53 & 0.06 & 0.54 & 1.00 & 0.42 \\
Brokerage_Size_std & 0.38 & 0.04 & 0.26 & 0.68 & 0.37 \\
Forecast_Freq_std & 0.48 & 0.00 & 0.50 & 1.00 & 0.39 \\
Firm_Exp_std & 0.42 & 0.05 & 0.30 & 0.83 & 0.39 \\
Gen_Exp_std & 0.42 & 0.07 & 0.32 & 0.77 & 0.37 \\
AT_std & 0.28 & 0.03 & 0.12 & 0.42 & 0.33 \\
IB_std & 0.37 & 0.07 & 0.26 & 0.64 & 0.32 \\
MVE_std & 0.27 & 0.03 & 0.11 & 0.39 & 0.33 \\
Spread_std & 0.24 & 0.00 & 0.40 & 1.00 & 0.43 \\
Turnover_std & 0.41 & 0.16 & 0.34 & 0.62 & 0.31 \\
News_Count_std & 0.42 & 0.16 & 0.34 & 0.65 & 0.32 \\
Following_std & 0.53 & 0.27 & 0.53 & 0.82 & 0.32
\end{tabular}

Panel D: Transformed Accuracy and Control Variable Descriptive Statistics

$\begin{array}{llllll}\text { Inst_Inv_std } & 0.39 & 0.15 & 0.32 & 0.58 & 0.30 \\ \text { Trans_Inst_Inv_std } & 0.41 & 0.17 & 0.35 & 0.59 & 0.30 \\ \text { Non_Trans_Inst_Inv_std } & 0.38 & 0.13 & 0.30 & 0.56 & 0.30 \\ \text { IA_Inst_Inv_std } & 0.38 & 0.14 & 0.31 & 0.57 & 0.30 \\ \text { Non_IA_Inst_Inv_std } & 0.40 & 0.16 & 0.34 & 0.60 & 0.30 \\ \text { IA_Trans_Inst_Inv_std } & 0.40 & 0.17 & 0.35 & 0.59 & 0.30 \\ \text { Non_IA_Trans_Inst_Inv_std } & 0.38 & 0.14 & 0.30 & 0.56 & 0.30 \\ \text { Growth_Inst_Inv_std } & 0.37 & 0.12 & 0.28 & 0.55 & 0.31 \\ \text { Non_Growth_Inst_Inv_std } & 0.39 & 0.15 & 0.33 & 0.58 & 0.30 \\ \text { Value_Inst_Inv_std } & 0.40 & 0.15 & 0.33 & 0.59 & 0.30 \\ \text { Non_Value_Inst_Inv_std } & 0.38 & 0.14 & 0.31 & 0.57 & 0.30\end{array}$

Variable subscripts are omitted. Variables are defined in Appendix A. Descriptive statistics are
based on 67,427 annual earnings forecast observations.
(continued on next page) 
TABLE 1 (continued)

Panel E: Correlations

\begin{tabular}{|c|c|c|c|c|c|c|c|c|c|c|c|c|}
\hline Variable & $(1)$ & $(2)$ & (3) & $(4)$ & $(5)$ & $(6)$ & $(7)$ & $(8)$ & $(9)$ & $(10)$ & $(11)$ & (12) \\
\hline Inst_Inv_std (1) & 1.00 & & & & & & & & & & & \\
\hline Bold_1std (2) & -0.02 & 1.00 & & & & & & & & & & \\
\hline Accuracy_std (3) & 0.02 & -0.06 & 1.00 & & & & & & & & & \\
\hline Days_Elapsed_std (4) & -0.02 & 0.06 & -0.02 & 1.00 & & & & & & & & \\
\hline Horizon_std (5) & -0.02 & 0.12 & -0.04 & 0.07 & 1.00 & & & & & & & \\
\hline $\begin{array}{l}\text { Lag_Accuracy_std } \\
\text { (6) }\end{array}$ & 0.00 & 0.01 & 0.08 & 0.00 & -0.02 & 1.00 & & & & & & \\
\hline Firm_Exp_std (7) & -0.07 & 0.00 & 0.00 & 0.05 & -0.01 & 0.01 & 1.00 & & & & & \\
\hline Gen_Exp_std (8) & -0.05 & 0.00 & 0.00 & 0.04 & 0.02 & 0.00 & 0.50 & 1.00 & & & & \\
\hline $\begin{array}{l}\text { Forecast_Freq_std } \\
\text { (9) }\end{array}$ & -0.01 & 0.02 & 0.01 & 0.10 & 0.00 & $\mathbf{0 . 0 3}$ & $\mathbf{0 . 0 3}$ & -0.01 & 1.00 & & & \\
\hline Follow_std (10) & -0.08 & 0.00 & -0.01 & $\mathbf{0 . 0 3}$ & 0.02 & 0.00 & 0.19 & 0.27 & 0.02 & 1.00 & & \\
\hline Sectors_std (11) & -0.03 & -0.02 & -0.02 & 0.06 & 0.04 & -0.01 & 0.09 & 0.11 & 0.04 & 0.30 & 1.00 & \\
\hline Allstar (12) & 0.00 & 0.01 & 0.00 & -0.01 & -0.03 & 0.00 & 0.14 & 0.17 & 0.00 & 0.11 & -0.02 & 1.00 \\
\hline Optimistic_Rec (13) & 0.01 & 0.00 & 0.01 & -0.01 & 0.00 & 0.01 & -0.03 & -0.01 & 0.02 & -0.04 & -0.01 & -0.03 \\
\hline $\begin{array}{l}\text { Brokerage_Size_std } \\
\text { (14) }\end{array}$ & -0.03 & 0.01 & -0.01 & 0.09 & 0.00 & -0.01 & 0.06 & 0.06 & 0.08 & 0.12 & 0.02 & 0.26 \\
\hline Underwriter (15) & -0.01 & $\mathbf{0 . 0 3}$ & 0.00 & 0.02 & 0.00 & 0.01 & 0.00 & 0.02 & $\mathbf{0 . 0 3}$ & 0.09 & 0.06 & -0.06 \\
\hline Guidance (16) & 0.00 & 0.04 & $\mathbf{0 . 0 3}$ & -0.13 & 0.13 & 0.02 & -0.02 & -0.02 & -0.03 & -0.01 & -0.02 & -0.01 \\
\hline$A T \_s t d(17)$ & 0.46 & -0.03 & 0.03 & -0.08 & -0.02 & 0.00 & -0.12 & -0.12 & -0.04 & -0.15 & -0.05 & -0.02 \\
\hline$I B \_s t d(18)$ & 0.38 & -0.02 & 0.01 & -0.05 & -0.02 & -0.01 & -0.07 & -0.09 & -0.02 & -0.09 & -0.01 & -0.03 \\
\hline$M V E \_s t d_{t}(19)$ & 0.50 & -0.03 & $\mathbf{0 . 0 3}$ & -0.09 & -0.02 & 0.01 & -0.11 & -0.12 & -0.04 & -0.15 & -0.05 & -0.03 \\
\hline Spread_std (20) & $\mathbf{0 . 0 3}$ & -0.01 & 0.00 & 0.01 & -0.01 & 0.00 & -0.02 & -0.03 & 0.00 & -0.10 & -0.03 & -0.02 \\
\hline Turnover_std (21) & -0.15 & 0.02 & 0.00 & -0.03 & -0.02 & 0.01 & -0.02 & -0.03 & -0.02 & -0.07 & -0.04 & -0.03 \\
\hline News_Count_std (22) & 0.37 & 0.01 & 0.04 & -0.09 & -0.02 & 0.01 & -0.10 & -0.09 & -0.04 & -0.11 & -0.06 & -0.01 \\
\hline Following_std & 0.03 & -0.01 & 0.05 & -0.16 & -0.05 & 0.02 & -0.10 & -0.10 & -0.09 & -0.08 & -0.10 & 0.04 \\
\hline
\end{tabular}


TABLE 1 (continued)

Panel E (continued)

\begin{tabular}{|c|c|c|c|c|c|c|c|c|c|c|}
\hline Variable & (13) & (14) & $(15)$ & $(16)$ & (17) & $(18)$ & (19) & $(20)$ & $(21)$ & $(22)$ \\
\hline Optimistic_Rec (13) & 1.00 & & & & & & & & & \\
\hline Brokerage_Size_std (14) & -0.05 & 1.00 & & & & & & & & \\
\hline Underwriter (15) & 0.00 & $\mathbf{0 . 0 3}$ & 1.00 & & & & & & & \\
\hline Guidance (16) & -0.01 & -0.06 & -0.03 & 1.00 & & & & & & \\
\hline$A T \_s t d(17)$ & $\mathbf{0 . 0 3}$ & -0.10 & -0.02 & 0.01 & 1.00 & & & & & \\
\hline$I B \_s t d(18)$ & $\mathbf{0 . 0 3}$ & -0.06 & -0.01 & -0.02 & 0.58 & 1.00 & & & & \\
\hline$M V E \_s t d(19)$ & $\mathbf{0 . 0 3}$ & -0.10 & -0.03 & 0.02 & 0.81 & 0.68 & 1.00 & & & \\
\hline Spread_std (20) & 0.02 & 0.00 & -0.01 & 0.00 & 0.02 & 0.06 & 0.06 & 1.00 & & \\
\hline Turnover_std (21) & $\mathbf{0 . 0 3}$ & -0.04 & -0.01 & 0.00 & -0.07 & -0.14 & -0.11 & -0.03 & 1.00 & \\
\hline News_Count_std (22) & 0.04 & -0.10 & -0.01 & 0.07 & 0.58 & 0.38 & 0.58 & -0.02 & 0.00 & 1.00 \\
\hline Following_std & 0.02 & -0.13 & -0.02 & 0.05 & 0.48 & 0.33 & 0.53 & -0.02 & 0.11 & 0.45 \\
\hline
\end{tabular}


TABLE 2

Institutional Ownership Determinants

\begin{tabular}{|c|c|c|c|c|c|c|c|c|c|c|c|c|}
\hline \multirow[b]{2}{*}{ Variable } & \multicolumn{2}{|c|}{ All Institutions } & \multicolumn{2}{|c|}{ Transient } & \multicolumn{2}{|c|}{ Investment Advisor } & \multicolumn{2}{|c|}{$\begin{array}{c}\text { Transient and } \\
\text { Investment Advisor }\end{array}$} & \multicolumn{2}{|c|}{ Growth } & \multicolumn{2}{|c|}{ Value } \\
\hline & Coeff & $\mathrm{p}$-value & Coeff & $\mathrm{p}$-value & Coeff & $\mathrm{p}$-value & Coeff & $\mathrm{p}$-value & Coeff & $\mathrm{p}$-value & Coeff & $\mathrm{p}$-value \\
\hline$A T \_s t d$ & $0.157 * * *$ & 0.000 & $0.121^{* * *}$ & 0.000 & $0.156 * * *$ & 0.000 & $0.119^{* * * *}$ & 0.000 & $0.087^{* * * *}$ & 0.000 & $0.209 * * *$ & 0.000 \\
\hline IB_std & $0.038 * * *$ & 0.000 & $0.035^{* * *}$ & 0.000 & $0.049 * * *$ & 0.000 & $0.038^{* * * *}$ & 0.000 & $0.025^{* * *}$ & 0.002 & $0.036^{* * *}$ & 0.000 \\
\hline$M V E \_s t d$ & $0.376 * * *$ & 0.000 & $0.293^{* * * *}$ & 0.000 & $0.395 * * *$ & 0.000 & $0.283^{* * * *}$ & 0.000 & $0.508^{* * *}$ & 0.000 & $0.249 * * *$ & 0.000 \\
\hline Spread_std & -0.004 & 0.479 & 0.009 & 0.163 & -0.006 & 0.300 & 0.011 & 0.109 & $0.011^{*}$ & 0.069 & -0.007 & 0.263 \\
\hline Turnover_std & $-0.040 * * *$ & 0.000 & $0.080^{* * *}$ & 0.000 & $-0.020^{*}$ & 0.054 & $0.086^{* * * *}$ & 0.000 & 0.003 & 0.795 & $-0.043 * * *$ & 0.000 \\
\hline News_Count_std & $0.170^{* * * *}$ & 0.000 & $0.152^{* * *}$ & 0.000 & $0.164 * * *$ & 0.000 & $0.149^{* * * *}$ & 0.000 & $0.137 * * *$ & 0.000 & $0.178^{* * *}$ & 0.000 \\
\hline Following_std & $-0.349 * * *$ & 0.000 & $-0.416^{* * *}$ & 0.000 & $-0.350^{* * * *}$ & 0.000 & $-0.429^{* * * *}$ & 0.000 & $-0.240^{* * * *}$ & 0.000 & $-0.371 * * *$ & 0.000 \\
\hline Constant & $0.362 * * *$ & 0.000 & $0.402 * * *$ & 0.000 & $0.343 * * *$ & 0.000 & $0.408^{* * * *}$ & 0.000 & $0.262 * * *$ & 0.000 & $0.399 * * *$ & 0.000 \\
\hline$R^{2}$ & 0.368 & & 0.242 & & 0.385 & & 0.238 & & 0.407 & & 0.299 & \\
\hline Observations & 67,427 & & 67,427 & & 67,427 & & 67,427 & & 67,427 & & 67,427 & \\
\hline
\end{tabular}

The dependent variable is $X X_{-} I n s t \_I n v_{-} s t d$. Variables subscripts are omitted. Variables are defined in Appendix A. Standard errors are clustered by firm. Two-tailed $\mathrm{p}$-values are reported $* * * \mathrm{p}<0.01, * * \mathrm{p}<$ $0.05, * \mathrm{p}<0.10$ 
TABLE 3

\section{Effect of Institutional Ownership on Earnings Forecast Boldness and Accuracy}

\begin{tabular}{lcccc} 
& \multicolumn{2}{c}{ Column $(1)$} & \multicolumn{2}{c}{ Column $(2)$} \\
Variable & DV $=$ Bold & $\mathrm{p}$-value & DV $=$ Accuracy_std & p-value \\
\hline Inst_Inv_std & $\mathbf{- 0 . 0 0 8}$ & $\mathbf{0 . 8 2 8}$ & $\mathbf{0 . 0 2 1} * * *$ & $\mathbf{0 . 0 0 0}$ \\
Bold & & & $-0.051^{* * *}$ & 0.000 \\
Days_Elapsed_std & $0.278^{* * *}$ & 0.000 & 0.000 & 0.994 \\
Horizon_std & $0.583^{* * *}$ & 0.000 & $-0.031^{* * *}$ & 0.000 \\
Lag_Accuracy_std & $0.058^{* *}$ & 0.011 & $0.080^{* * *}$ & 0.000 \\
Firm_Exp_std & -0.013 & 0.634 & $0.009^{*}$ & 0.058 \\
Gen_Exp_std & -0.050 & 0.130 & 0.003 & 0.628 \\
Forecast_Freq_std & $0.099^{* * *}$ & 0.000 & $0.012^{* * * *}$ & 0.004 \\
Follow_std & 0.008 & 0.797 & 0.001 & 0.869 \\
Sectors_std & $-0.126^{* * *}$ & 0.000 & $0.010^{* *}$ & 0.019 \\
Allstar & $0.075^{* *}$ & 0.039 & -0.002 & 0.668 \\
Optimistic_Rec & -0.015 & 0.459 & 0.002 & 0.513 \\
Brokerage_Sizesstd & -0.002 & 0.945 & -0.005 & 0.356 \\
Underwriter & $0.156^{* * *}$ & 0.000 & 0.002 & 0.701 \\
Guidance & $0.049^{* *}$ & 0.039 & $0.027^{* * *}$ & 0.000 \\
AT_std & $-0.134^{* * *}$ & 0.006 & 0.011 & 0.165 \\
IB_std & 0.060 & 0.111 & $-0.018^{* * *}$ & 0.004 \\
MVE_std & $-0.222^{* * *}$ & 0.000 & $-0.017^{*}$ & 0.071 \\
Spread_std & $-0.080^{* * *}$ & 0.005 & 0.000 & 0.977 \\
Turnover_std & $0.096^{* * *}$ & 0.002 & $-0.009^{*}$ & 0.075 \\
News_Count_std & $0.263^{* * *}$ & 0.000 & $0.016^{* *}$ & 0.016 \\
Following_std & 0.043 & 0.278 & $0.063^{* * *}$ & 0.000 \\
Constant & $-0.881^{* * *}$ & 0.000 & $0.595^{* * *}$ & 0.000 \\
& & & & \\
ROC Curve/R ${ }^{2}$ & 0.6199 & & 0.019 & \\
Observations & 67,427 & & 67,427 & \\
\hline & & & &
\end{tabular}

Variable subscripts are omitted. Variables are defined in Appendix A. Estimates include year and GICS sector fixed effects. Standard errors are clustered by analyst. Two-tailed p-values are reported $* * * \mathrm{p}<0.01, * * \mathrm{p}<0.05, * \mathrm{p}<0.10 . \mathrm{p}$-values in italics are reported using one-tailed p-values. 
TABLE 4

Effect of Ownership by Different Institution Types on Earnings Forecast Boldness and Accuracy

Panel A: Earnings Forecast Boldness

\begin{tabular}{|c|c|c|c|c|c|c|c|c|c|c|}
\hline \multirow[b]{2}{*}{ Variable } & \multicolumn{2}{|c|}{ Transient } & \multicolumn{2}{|c|}{ Investment Advisor } & \multicolumn{2}{|c|}{$\begin{array}{c}\text { Transient and } \\
\text { Investment Advisor }\end{array}$} & \multicolumn{2}{|c|}{ Growth } & \multicolumn{2}{|c|}{ Value } \\
\hline & Coeff. & p-value & Coeff. & p-value & Coeff. & p-value & Coeff. & p-value & Coeff. & p-value \\
\hline$X X_{\text {In_Inst_Inv_std }}$ & 0.037 & 0.215 & 0.091 & 0.105 & $0.073 *$ & 0.060 & -0.051 & 0.168 & -0.010 & 0.433 \\
\hline Non_XX_Inst_Inv_std & -0.051 & 0.313 & -0.100 & 0.149 & -0.080 & 0.113 & 0.031 & 0.546 & 0.001 & 0.989 \\
\hline Days_Elapsed_std & $0.279 * * *$ & 0.000 & $0.278 * * *$ & 0.000 & $0.279 * * *$ & 0.000 & $0.278 * * *$ & 0.000 & $0.279 * * *$ & 0.000 \\
\hline Horizon_std & $0.583 * * *$ & 0.000 & $0.583 * * *$ & 0.000 & $0.583 * * *$ & 0.000 & $0.583 * * *$ & 0.000 & $0.583 * * *$ & 0.000 \\
\hline Lag_Accuracy_std & $0.058 * *$ & 0.011 & $0.058 * *$ & 0.011 & $0.058 * *$ & 0.011 & $0.058 * *$ & 0.012 & $0.058 * *$ & 0.012 \\
\hline Firm_Exp_std & -0.014 & 0.625 & -0.014 & 0.613 & -0.014 & 0.619 & -0.013 & 0.645 & -0.013 & 0.636 \\
\hline Gen_Exp_std & -0.050 & 0.130 & -0.050 & 0.132 & -0.050 & 0.131 & -0.050 & 0.130 & -0.051 & 0.128 \\
\hline Forecast_Freq_std & $0.099 * * *$ & 0.000 & $0.099 * * *$ & 0.000 & $0.098 * * *$ & 0.000 & $0.099 * * *$ & 0.000 & $0.099 * * *$ & 0.000 \\
\hline Follow_std & 0.008 & 0.799 & 0.007 & 0.820 & 0.008 & 0.798 & 0.008 & 0.791 & 0.008 & 0.796 \\
\hline Sectors_std & $-0.126^{* * *}$ & 0.000 & $-0.126^{* * *}$ & 0.000 & $-0.125^{* * *}$ & 0.000 & $-0.126^{* * *}$ & 0.000 & $-0.126^{* * *}$ & 0.000 \\
\hline Allstar & $0.075^{* *}$ & 0.039 & $0.076^{* *}$ & 0.036 & $0.074 * *$ & 0.039 & $0.074 * *$ & 0.039 & $0.075^{* *}$ & 0.038 \\
\hline Optimistic_Rec & -0.015 & 0.447 & -0.015 & 0.449 & -0.016 & 0.437 & -0.015 & 0.469 & -0.015 & 0.460 \\
\hline Brokerage_Size_std & -0.002 & 0.937 & -0.002 & 0.939 & -0.003 & 0.932 & -0.002 & 0.938 & -0.002 & 0.939 \\
\hline Underwriter & $0.157 * * *$ & 0.000 & $0.156^{* * *}$ & 0.000 & $0.157 * * *$ & 0.000 & $0.156^{* * * *}$ & 0.000 & $0.156^{* * *}$ & 0.000 \\
\hline Guidance & $0.049^{* *}$ & 0.037 & $0.049 * *$ & 0.037 & $0.049 * *$ & 0.037 & $0.048 * *$ & 0.041 & $0.049^{* *}$ & 0.039 \\
\hline$A T \_s t d$ & $-0.132 * * *$ & 0.007 & $-0.135 * * *$ & 0.006 & $-0.131 * * *$ & 0.007 & $-0.137 * * *$ & 0.005 & $-0.134 * * *$ & 0.006 \\
\hline IB_std & 0.060 & 0.112 & 0.056 & 0.134 & 0.059 & 0.116 & 0.060 & 0.110 & 0.060 & 0.111 \\
\hline$M V E \_s t d$ & $-0.217 * * *$ & 0.000 & $-0.229 * * *$ & 0.000 & $-0.215^{* * *}$ & 0.000 & $-0.210 * * *$ & 0.000 & $-0.223 * * *$ & 0.000 \\
\hline Spread_std & $-0.081 * * *$ & 0.004 & $-0.080 * * *$ & 0.005 & $-0.082 * * *$ & 0.004 & $-0.080^{* * *}$ & 0.005 & $-0.080 * * *$ & 0.005 \\
\hline Turnover_std & $0.089 * * *$ & 0.005 & $0.090 * * *$ & 0.004 & $0.083^{*} * *$ & 0.008 & $0.098 * * *$ & 0.002 & $0.096 * * *$ & 0.002 \\
\hline News_Count_std & $0.264 * * *$ & 0.000 & $0.264 * * *$ & 0.000 & $0.264 * * *$ & 0.000 & $0.263 * * *$ & 0.000 & $0.263 * * *$ & 0.000 \\
\hline Following_std & 0.047 & 0.258 & 0.045 & 0.259 & 0.054 & 0.195 & 0.045 & 0.259 & 0.043 & 0.287 \\
\hline Constant & $-0.883^{* * *}$ & 0.000 & $-0.877 * * *$ & 0.000 & $-0.889 * * *$ & 0.000 & $-0.884 * * *$ & 0.000 & $-0.880 * * *$ & 0.000 \\
\hline ROC Curve & 0.620 & & 0.620 & & 0.620 & & 0.620 & & 0.620 & \\
\hline Observations & 67,427 & & 67,427 & & 67,427 & & 67,427 & & 67,427 & \\
\hline
\end{tabular}

The dependent variable is Bold. Variable subscripts are omitted. Variables are defined in Appendix A. Estimates include year and GICS sector fixed effects. Standard errors are clustered by analyst. Two-tailed $\mathrm{p}$-values are reported $* * * \mathrm{p}<0.01, * * \mathrm{p}<0.05, * \mathrm{p}<0.10$. P-values in italics are reported using one-tailed $\mathrm{p}$-values. (continued on next page) 
TABLE 4 (continued)

Panel B: Earnings Forecast Accuracy

\begin{tabular}{|c|c|c|c|c|c|c|c|c|c|c|}
\hline \multirow[b]{2}{*}{ Variable } & \multicolumn{2}{|c|}{ Transient } & \multicolumn{2}{|c|}{ Investment Advisor } & \multicolumn{2}{|c|}{$\begin{array}{c}\text { Transient and } \\
\text { Investment Advisor }\end{array}$} & \multicolumn{2}{|c|}{ Growth } & \multicolumn{2}{|c|}{ Value } \\
\hline & Coeff. & p-value & Coeff. & p-value & Coeff. & p-value & Coeff. & p-value & Coeff. & p-value \\
\hline$X X \_I n s t \_I n v \_s t d$ & $0.021 * *$ & 0.010 & 0.004 & 0.736 & $0.020 * *$ & 0.012 & 0.004 & 0.648 & $0.017 *$ & 0.093 \\
\hline Non_XX_Inst_Inv_std & 0.002 & 0.423 & $0.017 *$ & 0.085 & 0.003 & 0.365 & $0.017 * *$ & 0.022 & 0.004 & 0.352 \\
\hline Bold & $-0.051 * * *$ & 0.000 & $-0.051 * * *$ & 0.000 & $-0.051 * * *$ & 0.000 & $-0.051 * * *$ & 0.000 & $-0.051 * * *$ & 0.000 \\
\hline Days_Elapsed_std & 0.000 & 0.974 & 0.000 & 0.984 & 0.000 & 0.974 & 0.000 & 0.984 & 0.000 & 0.984 \\
\hline Horizon_std & $-0.031 * * *$ & 0.000 & $-0.031 * * *$ & 0.000 & $-0.031 * * *$ & 0.000 & $-0.031 * * *$ & 0.000 & $-0.031 * * *$ & 0.000 \\
\hline Lag_Accuracy_std & $0.081 * * *$ & 0.000 & $0.080 * * *$ & 0.000 & $0.081 * * *$ & 0.000 & $0.081 * * *$ & 0.000 & $0.081 * * *$ & 0.000 \\
\hline Firm_Exp_std & $0.009 *$ & 0.059 & $0.010 *$ & 0.054 & $0.009 *$ & 0.059 & $0.010 *$ & 0.056 & $0.010 *$ & 0.055 \\
\hline Gen_Exp_std & 0.003 & 0.637 & 0.003 & 0.645 & 0.003 & 0.634 & 0.003 & 0.642 & 0.003 & 0.637 \\
\hline Forecast_Freq_std & $0.012 * * *$ & 0.004 & $0.012 * * *$ & 0.004 & $0.012 * * *$ & 0.004 & $0.012 * * *$ & 0.004 & $0.012 * * *$ & 0.004 \\
\hline Follow_std & 0.001 & 0.859 & 0.001 & 0.847 & 0.001 & 0.853 & 0.001 & 0.854 & 0.001 & 0.834 \\
\hline Sectors_std & $-0.009 * *$ & 0.021 & $-0.009 * *$ & 0.020 & $-0.009 * *$ & 0.021 & $-0.010 * *$ & 0.020 & $-0.010 * *$ & 0.020 \\
\hline Allstar & -0.002 & 0.648 & -0.002 & 0.652 & -0.002 & 0.652 & -0.002 & 0.667 & -0.002 & 0.662 \\
\hline Optimistic_Rec & 0.002 & 0.538 & 0.002 & 0.504 & 0.002 & 0.536 & 0.002 & 0.508 & 0.002 & 0.505 \\
\hline Brokerage_Size_std & -0.005 & 0.351 & -0.005 & 0.354 & -0.005 & 0.347 & -0.005 & 0.352 & -0.005 & 0.352 \\
\hline Underwriter & 0.002 & 0.685 & 0.002 & 0.701 & 0.002 & 0.685 & 0.002 & 0.704 & 0.002 & 0.700 \\
\hline Guidance & $0.027 * * *$ & 0.000 & $0.027 * * *$ & 0.000 & $0.027 * * *$ & 0.000 & $0.027 * * *$ & 0.000 & $0.027 * * *$ & 0.000 \\
\hline$A T_{-}$std & 0.012 & 0.153 & 0.011 & 0.167 & 0.011 & 0.157 & 0.011 & 0.170 & 0.010 & 0.207 \\
\hline IB_std & $-0.018 * * *$ & 0.004 & $-0.017 * * *$ & 0.005 & $-0.018 * * *$ & 0.004 & $-0.018 * * *$ & 0.004 & $-0.018 * * *$ & 0.004 \\
\hline$M V E \_s t d$ & $-0.016^{*}$ & 0.089 & $-0.017 *$ & 0.081 & $-0.016^{*}$ & 0.086 & $-0.017^{*}$ & 0.079 & -0.016 & 0.110 \\
\hline Spread_std & 0.000 & 0.982 & 0.000 & 0.990 & 0.000 & 0.979 & 0.000 & 0.976 & 0.000 & 0.972 \\
\hline Turnover_std & $-0.012 * *$ & 0.032 & $-0.009^{*}$ & 0.098 & $-0.012 * *$ & 0.032 & $-0.009^{*}$ & 0.075 & $-0.010^{*}$ & 0.078 \\
\hline News_Count_std & $0.016^{* *}$ & 0.013 & $0.015^{* *}$ & 0.016 & $0.016^{* *}$ & 0.014 & $0.016^{* *}$ & 0.014 & $0.016^{* *}$ & 0.015 \\
\hline Following_std & $0.065 * * *$ & 0.000 & $0.063 * * *$ & 0.000 & $0.066^{* * * *}$ & 0.000 & $0.063 * * *$ & 0.000 & $0.064 * * *$ & 0.000 \\
\hline Constant & $0.593 * * *$ & 0.000 & $0.594 * * *$ & 0.000 & $0.592 * * *$ & 0.000 & $0.594 * * *$ & 0.000 & $0.593 * * *$ & 0.000 \\
\hline ROC Curve/ $R^{2}$ & 0.019 & & 0.019 & & 0.019 & & 0.019 & & 0.019 & \\
\hline Observations & 67,429 & & 67,429 & & 67,429 & & 67,429 & & 67,429 & \\
\hline
\end{tabular}

The dependent variable is Accuracy_std. Variable subscripts are omitted. Variables are defined in Appendix A. Estimates include year and GICS sector fixed effects. Standard errors are clustered by analyst. Two-tailed p-values are reported $* * * \mathrm{p}<0.01$, ** $\mathrm{p}<0.05, * \mathrm{p}<0.10$. p-values in italics are reported using one-tailed $\mathrm{p}$-values. 
TABLE 5

Effect of Ownership by Different Institution Types on Optimistic Earnings Forecast Boldness

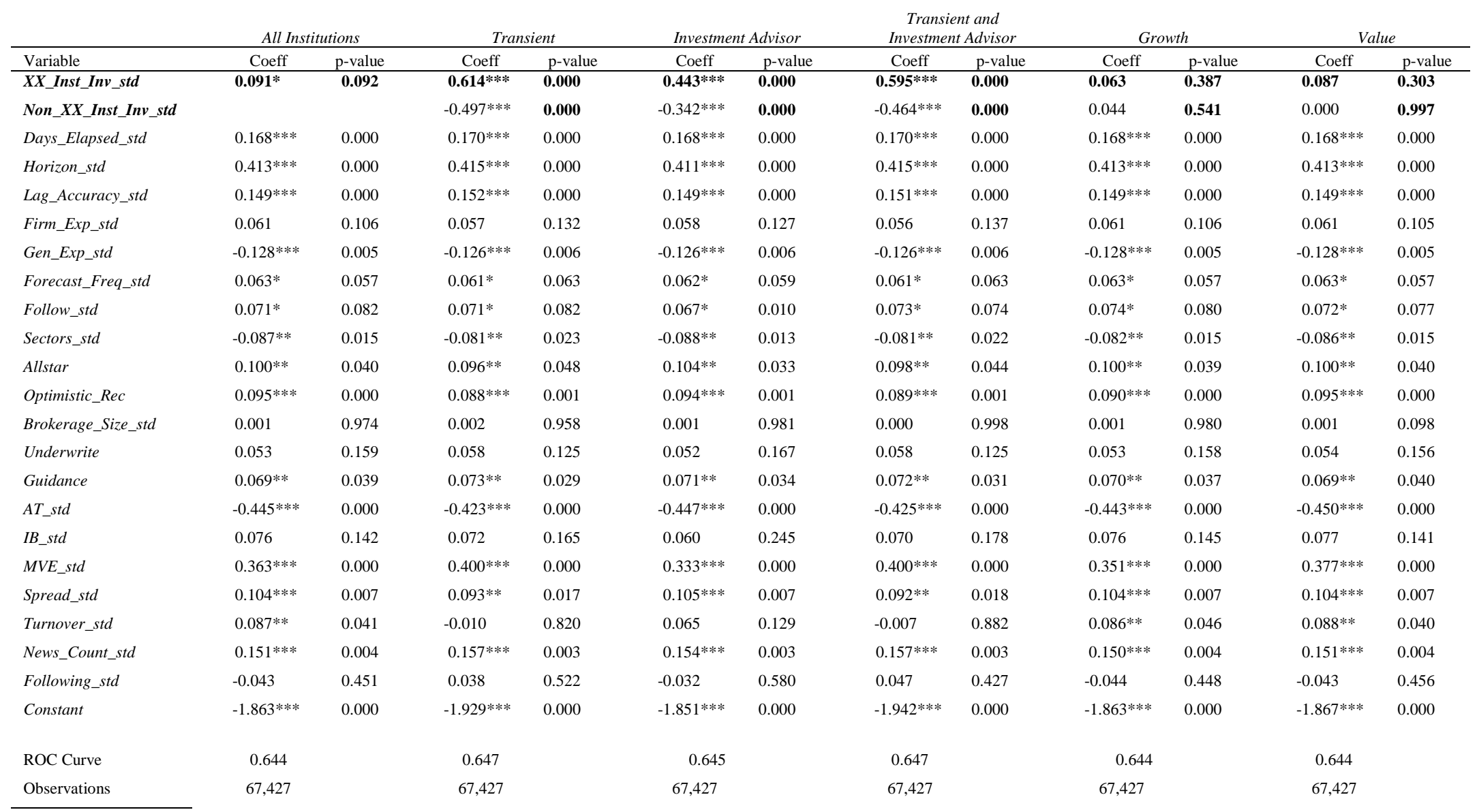

The dependent variable is Optimistic_Bold. Variable subscripts are omitted. Variables are defined in Appendix A. Estimates include year and GICS sector fixed effects. Standard errors are clustered by analyst. Twotailed $\mathrm{p}$-values are reported $* * * \mathrm{p}<0.01, * * \mathrm{p}<0.05, * \mathrm{p}<0.10$ 
TABLE 6

\section{Leader-Follower}

\begin{tabular}{|c|c|c|c|c|c|c|}
\hline Variable & $\begin{array}{c}\text { All } \\
\text { Institutions }\end{array}$ & Transient & $\begin{array}{l}\text { Investment } \\
\text { Advisor }\end{array}$ & $\begin{array}{c}\text { Transient and } \\
\text { Investment Advisor }\end{array}$ & Growth & Value \\
\hline \multirow[t]{2}{*}{$X X \_I n s t \_I n v \_s t d$} & -0.001 & -0.009 & -0.013 & -0.004 & 0.008 & 0.007 \\
\hline & $(0.895)$ & $(0.322)$ & $(0.367)$ & $(0.645)$ & $(0.436)$ & $(0.526)$ \\
\hline \multirow[t]{2}{*}{ Non_XX_Inst_Inv_std } & & 0.009 & 0.012 & 0.004 & -0.006 & -0.009 \\
\hline & & $(0.373)$ & $(0.388)$ & $(0.671)$ & $(0.522)$ & $(0.476)$ \\
\hline \multirow[t]{2}{*}{$A T \_s t d$} & $0.025 * *$ & $0.025^{* *}$ & $0.025 * *$ & $0.025 * *$ & $0.026^{* *}$ & $0.025 * *$ \\
\hline & $(0.014)$ & $(0.017)$ & $(0.014)$ & $(0.016)$ & $(0.014)$ & $(0.017)$ \\
\hline \multirow[t]{2}{*}{ IB_std } & 0.006 & 0.006 & 0.007 & 0.006 & 0.006 & 0.006 \\
\hline & $(0.375)$ & $(0.375)$ & $(0.343)$ & $(0.376)$ & $(0.380)$ & $(0.372)$ \\
\hline \multirow[t]{2}{*}{$M V E \_s t d$} & 0.013 & 0.011 & 0.014 & 0.012 & 0.010 & 0.014 \\
\hline & $(0.285)$ & $(0.331)$ & $(0.256)$ & $(0.317)$ & $(0.394)$ & $(0.234)$ \\
\hline \multirow[t]{2}{*}{ Spread_std } & $0.015 * *$ & $0.015 * * *$ & $0.015 * *$ & $0.015 * * *$ & $0.015^{* *}$ & $0.015^{* *}$ \\
\hline & $(0.010)$ & $(0.010)$ & $(0.011)$ & $(0.010)$ & $(0.011)$ & $(0.010)$ \\
\hline \multirow[t]{2}{*}{ Turnover_std } & $0.022 * * *$ & $0.023 * * *$ & $0.022 * * *$ & $0.022 * * *$ & $0.021 * * *$ & $0.022 * * *$ \\
\hline & $(0.001)$ & $(0.000)$ & $(0.001)$ & $(0.001)$ & $(0.001)$ & $(0.001)$ \\
\hline \multirow[t]{2}{*}{ News_Count_std } & 0.009 & 0.009 & 0.009 & 0.009 & 0.009 & 0.009 \\
\hline & $(0.246)$ & $(0.261)$ & $(0.254)$ & $(0.260)$ & $(0.257)$ & $(0.249)$ \\
\hline \multirow[t]{2}{*}{ Following_std } & $-0.056 * * *$ & $-0.057 * * *$ & $-0.057 * * *$ & $-0.057 * * *$ & $-0.056 * * *$ & $-0.056 * * *$ \\
\hline & $(0.000)$ & $(0.000)$ & $(0.000)$ & $(0.000)$ & $(0.000)$ & $(0.000)$ \\
\hline \multirow[t]{2}{*}{ Lag_LFR } & $0.091 * * *$ & $0.091 * * *$ & $0.091 * * *$ & $0.091 * * *$ & $0.091 * * *$ & $0.091 * * *$ \\
\hline & $(0.000)$ & $(0.000)$ & $(0.000)$ & $(0.000)$ & $(0.000)$ & $(0.000)$ \\
\hline \multirow[t]{2}{*}{ Constant } & $0.351 * * *$ & $0.351 * * *$ & $0.350 * * *$ & $0.351 * * *$ & $0.351 * * *$ & $0.351 * * *$ \\
\hline & $(0.000)$ & $(0.000)$ & $(0.000)$ & $(0.000)$ & $(0.000)$ & $(0.000)$ \\
\hline$R^{2}$ & 0.013 & 0.013 & 0.013 & 0.013 & 0.013 & 0.013 \\
\hline Observations & 66,582 & 66,582 & 66,582 & 66,582 & 66,582 & 66,582 \\
\hline
\end{tabular}

The dependent variable is LFR. Variable subscripts are omitted. Variables are defined in Appendix A. Estimates include year fixed effects. Standard errors are clustered by firm. Two-tailed p-values are reported in parentheses. $* * * \mathrm{p}<0.01, * * \mathrm{p}$-value $<0.05, * \mathrm{p}$-value $<0.10$ 
TABLE 7

Forecast Frequency

\begin{tabular}{|c|c|c|c|c|c|c|}
\hline Variable & $\begin{array}{c}\text { All } \\
\text { Institutions }\end{array}$ & Transient & $\begin{array}{l}\text { Investment } \\
\text { Advisor }\end{array}$ & $\begin{array}{c}\text { Transient and } \\
\text { Investment Advisor }\end{array}$ & Growth & Value \\
\hline \multirow[t]{2}{*}{$X X \_I n s t \_I n v \_s t d$} & -0.003 & 0.014 & -0.006 & 0.013 & $-0.023^{* *}$ & 0.015 \\
\hline & $(0.765)$ & $(0.154)$ & $(0.693)$ & $(0.181)$ & $(0.036)$ & $(0.243)$ \\
\hline \multirow[t]{2}{*}{ Non_XX_Inst_Inv_std } & & -0.016 & 0.003 & -0.015 & 0.013 & -0.017 \\
\hline & & $(0.176)$ & $(0.839)$ & $(0.201)$ & $(0.181)$ & $(0.220)$ \\
\hline \multirow{2}{*}{$A T \_s t d$} & $0.048 * * *$ & $0.049 * * *$ & $0.048 * * *$ & $0.049 * * *$ & $0.047 * * *$ & $0.047 * * *$ \\
\hline & $(0.000)$ & $(0.000)$ & $(0.000)$ & $(0.000)$ & $(0.000)$ & $(0.000)$ \\
\hline \multirow[t]{2}{*}{ IB_std } & $-0.015 * *$ & $-0.015 * *$ & $-0.015 * *$ & $-0.015 * *$ & $-0.015 *$ & $-0.015 * *$ \\
\hline & $(0.048)$ & $(0.046)$ & $(0.050)$ & $(0.046)$ & $(0.051)$ & $(0.049)$ \\
\hline \multirow[t]{2}{*}{$M V E \_s t d$} & $-0.038 * * *$ & $-0.036 * * *$ & $-0.037 * * *$ & $-0.036^{* * *}$ & $-0.032 * *$ & $-0.035 * * *$ \\
\hline & $(0.003)$ & $(0.004)$ & $(0.003)$ & $(0.004)$ & $(0.014)$ & $(0.006)$ \\
\hline \multirow[t]{2}{*}{ Spread_std } & 0.002 & 0.002 & 0.002 & 0.002 & 0.002 & 0.002 \\
\hline & $(0.726)$ & $(0.750)$ & $(0.726)$ & $(0.751)$ & $(0.692)$ & $(0.717)$ \\
\hline \multirow[t]{2}{*}{ Turnover_std } & $0.076 * * *$ & $0.074 * * *$ & $0.077 * * *$ & $0.074 * * *$ & $0.077 * * *$ & $0.077 * * *$ \\
\hline & $(0.000)$ & $(0.000)$ & $(0.000)$ & $(0.000)$ & $(0.000)$ & $(0.000)$ \\
\hline \multirow[t]{2}{*}{ News_Count_std } & $0.053 * * *$ & $0.053 * * *$ & $0.053 * * *$ & $0.053 * * *$ & $0.053 * * *$ & $0.053 * * *$ \\
\hline & $(0.000)$ & $(0.000)$ & $(0.000)$ & $(0.000)$ & $(0.000)$ & $(0.000)$ \\
\hline \multirow{2}{*}{ Following_std } & $0.062 * * *$ & $0.064 * * *$ & $0.062 * * *$ & $0.064 * * *$ & $0.062 * * *$ & $0.063 * * *$ \\
\hline & $(0.000)$ & $(0.000)$ & $(0.000)$ & $(0.000)$ & $(0.000)$ & $(0.000)$ \\
\hline \multirow[t]{2}{*}{ Constant } & $0.400 * * *$ & $0.399 * * *$ & $0.400 * * *$ & $0.399 * * *$ & $0.400 * * *$ & $0.399 * * *$ \\
\hline & $(0.000)$ & $(0.000)$ & $(0.000)$ & $(0.000)$ & $(0.000)$ & $(0.000)$ \\
\hline$R^{2}$ & 0.013 & 0.013 & 0.013 & 0.013 & 0.013 & 0.013 \\
\hline Observations & 67,117 & 67,117 & 67,117 & 67,117 & 67,117 & 67,117 \\
\hline
\end{tabular}


TABLE 8

The Effect of Resource Constraints on the Relationship between Ownership by Different Institution Types and

\section{Earnings Forecast Properties}

Panel A: Earnings Forecast Boldness

\begin{tabular}{|c|c|c|c|c|c|c|c|c|c|c|c|c|}
\hline \multirow[b]{2}{*}{ Variable } & \multicolumn{2}{|c|}{ All Institutions } & \multicolumn{2}{|c|}{ Transient } & \multicolumn{2}{|c|}{ Investment Advisor } & \multicolumn{2}{|c|}{$\begin{array}{c}\text { Transient and } \\
\text { Investment Advisor }\end{array}$} & \multicolumn{2}{|c|}{ Growth } & \multicolumn{2}{|c|}{ Value } \\
\hline & Coeff & $\mathrm{p}$-value & Coeff & p-value & Coeff & $\mathrm{p}$-value & Coeff & $\mathrm{p}$-value & Coeff & p-value & Coeff & $\mathrm{p}$-value \\
\hline $\begin{array}{l}X X \_I n s t \_I n v \_s t d \\
X X \_I n s t \_I n v \_s t d *\end{array}$ & 0.004 & 0.722 & -0.006 & 0.714 & $0.043^{*}$ & 0.073 & -0.004 & 0.803 & 0.013 & 0.464 & $-0.036^{*}$ & 0.083 \\
\hline $\begin{array}{l}\text { Follow_std } \\
X X_{\text {IInst_Inv_std }}\end{array}$ & 0.025 & 0.137 & 0.008 & 0.753 & 0.031 & 0.420 & 0.009 & 0.702 & -0.027 & 0.273 & 0.046 & 0.136 \\
\hline $\begin{array}{l}\text { Sectors_std } \\
\boldsymbol{X} \boldsymbol{X} \_I n s t \_I n v \_s t \boldsymbol{t} *\end{array}$ & -0.023 & 0.111 & -0.001 & 0.967 & -0.048 & 0.123 & 0.004 & 0.849 & -0.026 & 0.219 & 0.019 & 0.473 \\
\hline Brokerage_Size_std & -0.016 & 0.310 & 0.027 & 0.249 & -0.039 & 0.251 & 0.033 & 0.146 & 0.000 & 0.999 & 0.017 & 0.564 \\
\hline $\begin{array}{l}\text { Non_XX_Inst_Inv_std } \\
\text { Non_XX_Inst_Inv_std }\end{array}$ & & & 0.007 & 0.672 & $-0.040^{*}$ & 0.090 & 0.005 & 0.753 & -0.008 & 0.627 & $0.037 *$ & 0.074 \\
\hline $\begin{array}{l}\text { * Sectors_std } \\
\text { Non_XX_Inst_Inv_std }\end{array}$ & & & -0.020 & 0.318 & 0.028 & 0.367 & -0.025 & 0.221 & 0.000 & 0.986 & -0.040 & 0.139 \\
\hline * Brokerage_Size_std & & & $-0.038^{*}$ & 0.010 & 0.025 & 0.457 & $-0.044 *$ & 0.054 & -0.013 & 0.577 & -0.033 & 0.253 \\
\hline Days_Elapsed_std & $0.057 * * *$ & 0.000 & $0.057 * * *$ & 0.000 & $0.057 * * *$ & 0.000 & $0.057 * * *$ & 0.000 & $0.056 * * *$ & 0.000 & $0.056^{* * *}$ & 0.000 \\
\hline Horizon_std & $0.115 * * *$ & 0.000 & $0.115^{* * * *}$ & 0.000 & $0.115 * * *$ & 0.000 & $0.115^{* * *}$ & 0.000 & $0.115 * * *$ & 0.000 & $0.115^{* * *}$ & 0.000 \\
\hline Lag_Accuracy_std & $0.012 * *$ & 0.010 & $0.012 * *$ & 0.010 & $0.012 * *$ & 0.011 & $0.012 * *$ & 0.010 & $0.012 * *$ & 0.011 & $0.012 * *$ & 0.011 \\
\hline Firm_Exp_std & -0.002 & 0.646 & -0.003 & 0.640 & -0.003 & 0.627 & -0.003 & 0.632 & -0.002 & 0.646 & -0.003 & 0.644 \\
\hline Gen_Exp_std & -0.010 & 0.126 & -0.010 & 0.123 & -0.010 & 0.129 & -0.010 & 0.124 & -0.010 & 0.130 & -0.010 & 0.127 \\
\hline Forecast_Freq_std & $0.019 * * *$ & 0.000 & $0.019 * * *$ & 0.000 & $0.019 * * *$ & 0.000 & $0.019 * * *$ & 0.000 & $0.019 * * *$ & 0.000 & $0.019 * * *$ & 0.000 \\
\hline Allstar & $0.015 * *$ & 0.043 & $0.015^{* *}$ & 0.042 & $0.015 * *$ & 0.040 & $0.015 * *$ & 0.041 & $0.015^{* * *}$ & 0.043 & $0.015^{* *}$ & 0.041 \\
\hline Optimistic_Rec & -0.003 & 0.479 & -0.003 & 0.468 & -0.003 & 0.473 & -0.003 & 0.457 & -0.003 & 0.488 & -0.003 & 0.492 \\
\hline Brokerage_Size_std & 0.006 & 0.487 & 0.003 & 0.736 & 0.005 & 0.607 & 0.002 & 0.789 & 0.005 & 0.594 & 0.005 & 0.535 \\
\hline Underwriter & $0.030 * * *$ & 0.000 & $0.030^{* * * *}$ & 0.000 & $0.030 * * *$ & 0.000 & $0.030^{* * *}$ & 0.000 & $0.030^{* * *}$ & 0.000 & $0.030 * * *$ & 0.000 \\
\hline Guidance & $0.010^{*}$ & 0.052 & $0.010^{*}$ & 0.052 & $0.010^{*}$ & 0.050 & $0.010^{*}$ & 0.051 & $0.009 *$ & 0.056 & $0.009 *$ & 0.056 \\
\hline$A T \_s t d$ & $-0.027 * * *$ & 0.004 & $-0.027 * * *$ & 0.005 & $-0.027 * * *$ & 0.004 & $-0.027 * * *$ & 0.005 & $-0.027 * * *$ & 0.004 & $-0.026 * * *$ & 0.006 \\
\hline IB_std & 0.012 & 0.108 & 0.012 & 0.106 & 0.011 & 0.132 & 0.012 & 0.108 & 0.012 & 0.107 & 0.012 & 0.106 \\
\hline$M V E \_s t d$ & $-0.043 * * *$ & 0.000 & $-0.042 * * *$ & 0.000 & $-0.045 * * *$ & 0.000 & $-0.042 * * *$ & 0.000 & $-0.041 * * *$ & 0.000 & $-0.044 * * *$ & 0.000 \\
\hline
\end{tabular}


TABLE 8 (continued)

\begin{tabular}{|c|c|c|c|c|c|c|c|c|c|c|c|c|}
\hline \multirow[b]{2}{*}{ Variable } & \multicolumn{2}{|c|}{ All Institutions } & \multicolumn{2}{|c|}{ Transient } & \multicolumn{2}{|c|}{ Investment Advisor } & \multicolumn{2}{|c|}{$\begin{array}{c}\text { Transient and } \\
\text { Investment Advisor }\end{array}$} & \multicolumn{2}{|c|}{ Growth } & \multicolumn{2}{|c|}{ Value } \\
\hline & Coeff & $\mathrm{p}$-value & Coeff & $\mathrm{p}$-value & Coeff & $\mathrm{p}$-value & Coeff & $p$-value & Coeff & $\mathrm{p}$-value & Coeff & $p$-value \\
\hline Turnover_std & $0.019^{* * * *}$ & 0.002 & $0.017 * * *$ & 0.005 & $0.018^{* * * *}$ & 0.004 & $0.016^{* * *}$ & 0.009 & $0.019 * * *$ & 0.002 & $0.019 * * *$ & 0.002 \\
\hline IB_std & 0.012 & 0.108 & 0.012 & 0.106 & 0.011 & 0.132 & 0.012 & 0.108 & 0.012 & 0.107 & 0.012 & 0.106 \\
\hline$M V E \_s t d$ & $-0.043 * * *$ & 0.000 & $-0.042 * * *$ & 0.000 & $-0.045 * * *$ & 0.000 & $-0.042 * * *$ & 0.000 & $-0.041 * * *$ & 0.000 & $-0.044 * * *$ & 0.000 \\
\hline Spread_std & $-0.015 * * *$ & 0.006 & $-0.015 * * *$ & 0.006 & $-0.015^{* * * *}$ & 0.006 & $-0.015 * * *$ & 0.005 & $-0.015 * * *$ & 0.006 & $-0.015 * * *$ & 0.006 \\
\hline Turnover_std & $0.019^{* * * *}$ & 0.002 & $0.017^{* * * *}$ & 0.005 & $0.018 * * *$ & 0.004 & $0.016^{* * *}$ & 0.009 & $0.019 * * *$ & 0.002 & $0.019^{* * *}$ & 0.002 \\
\hline News_Count_std & $0.052^{* * * *}$ & 0.000 & $0.052 * * *$ & 0.000 & $0.052 * * *$ & 0.000 & $0.052^{* * *}$ & 0.000 & $0.052 * * *$ & 0.000 & $0.052^{* * * *}$ & 0.000 \\
\hline Following_std & 0.007 & 0.394 & 0.007 & 0.365 & 0.007 & 0.363 & 0.009 & 0.285 & 0.007 & 0.363 & 0.007 & 0.404 \\
\hline Constant & $0.307^{* * * *}$ & 0.000 & $0.308^{* * * *}$ & 0.000 & $0.309 * * *$ & 0.000 & $0.307 * * *$ & 0.000 & $0.306 * * *$ & 0.000 & $0.309^{* * *}$ & 0.000 \\
\hline$R^{2}$ & 0.036 & & 0.036 & & 0.036 & & 0.036 & & 0.036 & & 0.036 & \\
\hline Observations & 67,427 & & 67,427 & & 67,427 & & 67,427 & & 67,427 & & 67,427 & \\
\hline
\end{tabular}

The dependent variable is Bold. Variable subscripts are omitted. Variables are defined in Appendix A. Estimates include year and GICS sector fixed effects. Standard errors are clustered by analyst. Two-tailed p-values are reported *** $\mathrm{p}<0.01, * * \mathrm{p}<0.05, * \mathrm{p}<0.10$. 
TABLE 8 (continued)

Panel B: Optimistic Earnings Forecast Boldness

\begin{tabular}{|c|c|c|c|c|c|c|c|c|c|c|c|c|}
\hline \multirow[b]{2}{*}{ Variable } & \multicolumn{2}{|c|}{ All Institutions } & \multicolumn{2}{|c|}{ Transient } & \multicolumn{2}{|c|}{ Investment Advisor } & \multicolumn{2}{|c|}{$\begin{array}{c}\text { Transient and } \\
\text { Investment Advisor }\end{array}$} & \multicolumn{2}{|c|}{ Growth } & \multicolumn{2}{|c|}{ Value } \\
\hline & Coeff & $\mathrm{p}$-value & Coeff & $\mathrm{p}$-value & Coeff & $p$-value & Coeff & $\mathrm{p}$-value & Coeff & $p$-value & Coeff & $\mathrm{p}$-value \\
\hline $\begin{array}{l}X X \_I n s t \_I n v \_s t d \\
X X \_I n s t \_I n v \_s t d *\end{array}$ & -0.002 & 0.776 & $0.049 * * *$ & 0.000 & $0.053 * * *$ & 0.002 & $0.044 * * *$ & 0.000 & $0.022 *$ & 0.075 & -0.021 & 0.158 \\
\hline $\begin{array}{l}\text { Follow_std } \\
X X \_I n s t \_I n v \_s t d *\end{array}$ & 0.016 & 0.174 & $0.045^{* *}$ & 0.015 & -0.012 & 0.662 & $0.043^{* *}$ & 0.019 & -0.021 & 0.238 & $0.068^{* * *}$ & 0.003 \\
\hline $\begin{array}{l}\text { Sectors_std } \\
X X_{-} \text {Inst_Inv_std * }\end{array}$ & 0.008 & 0.422 & -0.010 & 0.537 & -0.006 & 0.800 & -0.005 & 0.734 & $-0.026 *$ & 0.085 & 0.009 & 0.654 \\
\hline Brokerage_Size_std & 0.005 & 0.653 & -0.001 & 0.947 & 0.002 & 0.920 & 0.005 & 0.741 & 0.012 & 0.457 & -0.006 & 0.778 \\
\hline $\begin{array}{l}\text { Non_XX_Inst_Inv_std } \\
\text { Non_XX_Inst_Inv_std }\end{array}$ & & & $-0.050^{* * * *}$ & 0.000 & $-0.054 * * *$ & 0.001 & $-0.044 * * *$ & 0.000 & $-0.022^{*}$ & 0.084 & 0.017 & 0.266 \\
\hline $\begin{array}{l}\text { * Sectors_std } \\
\text { Non_XX_Inst_Inv_std }\end{array}$ & & & 0.017 & 0.268 & 0.015 & 0.505 & 0.013 & 0.397 & $0.033^{* *}$ & 0.036 & 0.001 & 0.941 \\
\hline * Brokerage_Size_std & & & 0.004 & 0.828 & 0.002 & 0.942 & -0.003 & 0.847 & -0.005 & 0.749 & 0.007 & 0.730 \\
\hline Days_Elapsed_std & $0.018 * * *$ & 0.000 & $0.018^{* * *}$ & 0.000 & $0.018 * * *$ & 0.000 & $0.018 * * *$ & 0.000 & $0.018 * * *$ & 0.000 & $0.018 * * *$ & 0.000 \\
\hline Horizon_std & $0.041 * * *$ & 0.000 & $0.042 * * *$ & 0.000 & $0.041 * * *$ & 0.000 & $0.042 * * *$ & 0.000 & $0.041 * * *$ & 0.000 & $0.041 * * *$ & 0.000 \\
\hline Lag_Accuracy_std & $0.015 * * *$ & 0.000 & $0.015^{* * *}$ & 0.000 & $0.015 * * *$ & 0.000 & $0.015 * * *$ & 0.000 & $0.015^{* * *}$ & 0.000 & $0.015^{* * *}$ & 0.000 \\
\hline Firm_Exp_std & $0.006^{*}$ & 0.086 & 0.006 & 0.107 & 0.006 & 0.106 & 0.006 & 0.111 & $0.006^{*}$ & 0.090 & $0.006^{*}$ & 0.088 \\
\hline Gen_Exp_std & $-0.013 * * *$ & 0.004 & $-0.013 * * *$ & 0.005 & $-0.013 * * *$ & 0.005 & $-0.013 * * *$ & 0.005 & $-0.013 * * *$ & 0.005 & $-0.013 * * *$ & 0.005 \\
\hline Forecast_Freq_std & $0.006^{*}$ & 0.065 & $0.006^{*}$ & 0.077 & $0.006^{*}$ & 0.066 & $0.006^{*}$ & 0.078 & $0.006^{*}$ & 0.064 & $0.006 *$ & 0.067 \\
\hline Allstar & $0.010 * *$ & 0.045 & $0.009^{*}$ & 0.054 & $0.010 * *$ & 0.037 & $0.010 * *$ & 0.050 & $0.010 * *$ & 0.043 & $0.010 * *$ & 0.044 \\
\hline Optimistic_Rec & $0.010 * * *$ & 0.001 & $0.009 * * *$ & 0.001 & $0.010 * * *$ & 0.001 & $0.009 * * *$ & 0.001 & $0.010 * * *$ & 0.001 & $0.010 * * *$ & 0.000 \\
\hline Brokerage_Size_std & -0.002 & 0.759 & -0.001 & 0.889 & -0.001 & 0.813 & -0.001 & 0.838 & -0.002 & 0.710 & 0.000 & 0.958 \\
\hline Underwriter & 0.005 & 0.207 & 0.00517 & 0.162 & 0.00447 & 0.226 & 0.00513 & 0.166 & 0.00468 & 0.206 & 0.00464 & 0.209 \\
\hline Guidance & $0.007 * *$ & 0.048 & $0.008 * *$ & 0.036 & $0.008 * *$ & 0.042 & $0.008 * *$ & 0.038 & $0.007 * *$ & 0.046 & $0.007 *$ & 0.052 \\
\hline$A T_{-} s t d$ & $-0.043 * * *$ & 0.000 & $-0.041 * * *$ & 0.000 & $-0.044 * * *$ & 0.000 & $-0.041 * * *$ & 0.000 & $-0.043^{* * * *}$ & 0.000 & $-0.043 * * *$ & 0.000 \\
\hline$I B \_s t d$ & $0.009 *$ & 0.085 & $0.008 *$ & 0.090 & 0.007 & 0.146 & $0.008 *$ & 0.097 & $0.009 *$ & 0.087 & $0.009^{*}$ & 0.083 \\
\hline$M V E \_s t d$ & $0.034 * * *$ & 0.000 & $0.039 * * *$ & 0.000 & $0.031 * * *$ & 0.000 & $0.039 * * *$ & 0.000 & $0.033^{* * *}$ & 0.000 & $0.035^{* * *}$ & 0.000 \\
\hline Spread_std & $0.011 * * *$ & 0.008 & $0.019 * *$ & 0.016 & $0.011 * * *$ & 0.007 & $0.010 * *$ & 0.016 & $0.011 * * *$ & 0.009 & $0.011 * * *$ & 0.008 \\
\hline Turnover_std & $0.009 * *$ & 0.036 & -0.001 & 0.902 & 0.007 & 0.113 & 0.000 & 0.958 & $0.009 * *$ & 0.039 & $0.009 * *$ & 0.036 \\
\hline News_Count_std & $0.016 * * *$ & 0.003 & $0.017 * * *$ & 0.001 & $0.016 * * *$ & 0.002 & $0.017 * * *$ & 0.001 & $0.016 * * *$ & 0.002 & $0.016 * * *$ & 0.002 \\
\hline
\end{tabular}


TABLE 8 (continued)

\begin{tabular}{|c|c|c|c|c|c|c|c|c|c|c|c|c|}
\hline \multirow[b]{2}{*}{ Variable } & \multicolumn{2}{|c|}{ All Institutions } & \multicolumn{2}{|c|}{ Transient } & \multicolumn{2}{|c|}{ Investment Advisor } & \multicolumn{2}{|c|}{$\begin{array}{c}\text { Transient and } \\
\text { Investment Advisor }\end{array}$} & \multicolumn{2}{|c|}{ Growth } & \multicolumn{2}{|c|}{ Value } \\
\hline & Coeff & $\mathrm{p}$-value & Coeff & $\mathrm{p}$-value & Coeff & $\mathrm{p}$-value & Coeff & $\mathrm{p}$-value & Coeff & $\mathrm{p}$-value & Coeff & $\mathrm{p}$-value \\
\hline Following_std & -0.005 & 0.351 & 0.003 & 0.659 & -0.004 & 0.447 & 0.004 & 0.545 & -0.005 & 0.348 & -0.005 & 0.358 \\
\hline Constant & $0.161^{* * *}$ & 0.000 & $0.156^{* * *}$ & 0.000 & $0.163 * * *$ & 0.000 & $0.155^{* * *}$ & 0.000 & $0.161 * * *$ & 0.000 & $0.162 * * *$ & 0.000 \\
\hline$R^{2}$ & 0.026 & & 0.027 & & 0.026 & & 0.027 & & 0.026 & & 0.026 & \\
\hline Observations & 67,427 & & 67,427 & & 67,427 & & 67,427 & & 67,427 & & 67,427 & \\
\hline
\end{tabular}

The dependent variable is Optimistic_Bold. Variable subscripts are omitted. Variables are defined in Appendix A. Estimates include year and GICS sector fixed effects. Standard errors are clustered by analyst. Twotailed $\mathrm{p}$-values are reported $* * * \mathrm{p}<0.01, * * \mathrm{p}<0.05, * \mathrm{p}<0.10$ 
TABLE 8 (continued)

Panel C: Earnings Forecast Accurac

\begin{tabular}{|c|c|c|c|c|c|c|c|c|c|c|c|c|}
\hline \multirow[b]{2}{*}{ Variable } & \multicolumn{2}{|c|}{ All Institutions } & \multicolumn{2}{|c|}{ Transient } & \multicolumn{2}{|c|}{ Investment Advisor } & \multicolumn{2}{|c|}{$\begin{array}{c}\text { Transient and } \\
\text { Investment Advisor }\end{array}$} & \multicolumn{2}{|c|}{ Growth } & \multicolumn{2}{|c|}{ Value } \\
\hline & Coeff & $p$-value & Coeff & $p$-value & Coeff & $p$-value & Coeff & $p$-value & Coeff & $\mathrm{p}$-value & Coeff & $p$-value \\
\hline $\begin{array}{l}\text { XX_Inst_Inv_std } \\
\text { XX_Inst_Inv_std } *\end{array}$ & $0.021^{* *}$ & 0.046 & $0.024 *$ & 0.084 & -0.003 & 0.906 & 0.022 & 0.115 & -0.001 & 0.972 & -0.005 & 0.794 \\
\hline $\begin{array}{l}\text { Follow_std } \\
X X \_I n s t \_I n v \_s t d *\end{array}$ & 0.000 & 0.498 & -0.005 & 0.817 & 0.012 & 0.735 & 0.005 & 0.840 & 0.031 & 0.184 & -0.006 & 0.831 \\
\hline $\begin{array}{l}\text { Sectors_std } \\
X X \_I n s t \_I n v \_s t d *\end{array}$ & 0.002 & 0.427 & $-0.036^{*}$ & 0.053 & -0.023 & 0.426 & $-0.043 * *$ & 0.018 & 0.025 & 0.194 & -0.008 & 0.751 \\
\hline Brokerage_Size_std & -0.003 & 0.417 & $0.037 *$ & 0.080 & 0.033 & 0.328 & $0.039 *$ & 0.060 & $-0.049 * *$ & 0.026 & $0.072^{* * * *}$ & 0.008 \\
\hline $\begin{array}{l}\text { Non_XX_Inst_Inv_std } \\
\text { Non_XX_Inst_Inv_std }\end{array}$ & & & -0.004 & 0.611 & 0.024 & 0.135 & 0.000 & 0.492 & $0.021 *$ & 0.084 & $0.024 *$ & 0.094 \\
\hline $\begin{array}{l}* \text { Follow_std } \\
\text { Non_XX_Inst_Inv_std }\end{array}$ & & & 0.006 & 0.391 & -0.013 & 0.640 & -0.003 & 0.554 & -0.024 & 0.844 & 0.010 & 0.362 \\
\hline $\begin{array}{l}\text { *Sectors_std } \\
\text { Non_XX_Inst_Inv_std }\end{array}$ & & & 0.035 ** & 0.026 & 0.025 & 0.189 & $0.040 * *$ & 0.014 & -0.019 & 0.844 & 0.010 & 0.345 \\
\hline * Brokerage_Size_std & & & $-0.031 *$ & 0.070 & -0.035 & 0.147 & $-0.034 *$ & 0.052 & 0.037 & 0.953 & $-0.074 * * *$ & 0.004 \\
\hline Bold_lstd & $-0.051 * * *$ & 0.000 & $-0.051 * * *$ & 0.000 & $-0.051 * * *$ & 0.000 & $-0.051 * * *$ & 0.000 & $-0.051 * * *$ & 0.000 & $-0.051 * * *$ & 0.000 \\
\hline Days_Elapsed_std & 0.000 & & 0.000 & 0.981 & 0.000 & 0.976 & 0.000 & 0.981 & 0.000 & 0.973 & 0.000 & 0.993 \\
\hline Horizon_std & $-0.031 * * *$ & 0.000 & $-0.031 * * *$ & 0.000 & $-0.031 * * *$ & 0.000 & $-0.031 * * *$ & 0.000 & $-0.031 * * *$ & 0.000 & $-0.031 * * *$ & 0.000 \\
\hline Lag_Accuracy_std & $0.081 * * *$ & 0.000 & $0.081 * * *$ & 0.000 & $0.081 * * *$ & 0.000 & $0.081 * * *$ & 0.000 & $0.081 * * *$ & 0.000 & $0.081^{* * * *}$ & 0.000 \\
\hline Firm_Exp_std & $0.009^{*}$ & 0.058 & $0.009^{*}$ & 0.059 & $0.010 *$ & 0.054 & $0.009 *$ & 0.059 & $0.010 *$ & 0.055 & $0.010^{*}$ & 0.055 \\
\hline Gen_Exp_std & 0.003 & 0.628 & 0.003 & 0.648 & 0.003 & 0.651 & 0.003 & 0.650 & 0.003 & 0.654 & 0.003 & 0.641 \\
\hline Forecast_Freq_std & $0.012 * * *$ & 0.004 & $0.012 * * *$ & 0.004 & $0.012^{* * * *}$ & 0.004 & $0.012^{* * *}$ & 0.004 & $0.012 * * *$ & 0.004 & $0.012^{* * * *}$ & 0.004 \\
\hline Follow_std & 0.001 & 0.916 & 0.001 & 0.937 & 0.001 & 0.864 & 0.000 & 0.996 & -0.001 & 0.906 & -0.000 & 0.957 \\
\hline Sectors_std & -0.011 & 0.105 & -0.008 & 0.249 & -0.011 & 0.102 & -0.007 & 0.331 & $-0.011 *$ & 0.097 & -0.010 & 0.124 \\
\hline Allstar & -0.002 & 0.666 & -0.002 & 0.653 & -0.002 & 0.660 & -0.002 & 0.671 & -0.002 & 0.663 & -0.002 & 0.677 \\
\hline Optimistic_Rec & 0.002 & 0.511 & 0.002 & 0.534 & 0.002 & 0.513 & 0.002 & 0.532 & 0.002 & 0.491 & 0.002 & 0.487 \\
\hline Brokerage_Size_std & -0.003 & 0.647 & -0.008 & 0.304 & -0.003 & 0.686 & -0.008 & 0.311 & -0.002 & 0.818 & -0.005 & 0.491 \\
\hline Underwriter & 0.002 & 0.705 & 0.002 & 0.706 & 0.002 & 0.697 & 0.002 & 0.710 & 0.002 & 0.724 & 0.001 & 0.739 \\
\hline Guidance & $0.027 * * *$ & 0.000 & $0.027 * * *$ & 0.000 & $0.027 * * *$ & 0.000 & $0.027 * * *$ & 0.000 & $0.027 * * *$ & 0.000 & $0.027^{* * * *}$ & 0.000 \\
\hline$A T \_s t d$ & 0.011 & 0.166 & 0.011 & 0.169 & 0.011 & 0.169 & 0.011 & 0.179 & 0.011 & 0.177 & 0.010 & 0.209 \\
\hline IB_std & $-0.018 * * * *$ & 0.004 & $-0.018 * * *$ & 0.004 & $-0.017 * * *$ & 0.005 & $-0.018^{* * *}$ & 0.004 & $-0.017 * * *$ & 0.005 & $-0.018^{* * * *}$ & 0.005 \\
\hline$M V E \_s t d$ & $-0.017 *$ & 0.071 & $-0.016^{*}$ & 0.087 & $-0.017^{*}$ & 0.082 & $-0.017 *$ & 0.083 & $-0.018^{*}$ & 0.071 & $-0.016^{*}$ & 0.010 \\
\hline Spread_std & 0.000 & 0.976 & 0.000 & 0.988 & 0.000 & 0.989 & 0.000 & 0.974 & 0.000 & 0.971 & 0.000 & 0.977 \\
\hline Turnover_std & $-0.009 *$ & 0.075 & $-0.012 * *$ & 0.031 & $-0.009^{*}$ & 0.099 & $-0.012 * *$ & 0.031 & $-0.009^{*}$ & 0.072 & $-0.009^{*}$ & 0.075 \\
\hline News_Count_std & $0.016^{* *}$ & 0.014 & $0.016^{* *}$ & 0.013 & $0.016^{* *}$ & 0.015 & $0.016 * *$ & 0.013 & $0.015^{* *}$ & 0.016 & $0.016^{* *}$ & 0.015 \\
\hline
\end{tabular}


TABLE 8 (continued)

\begin{tabular}{|c|c|c|c|c|c|c|c|c|c|c|c|c|}
\hline \multirow[b]{2}{*}{ Variable } & \multicolumn{2}{|c|}{ All Institutions } & \multicolumn{2}{|c|}{ Transient } & \multicolumn{2}{|c|}{ Investment Advisor } & \multicolumn{2}{|c|}{$\begin{array}{c}\text { Transient and } \\
\text { Investment Advisor }\end{array}$} & \multicolumn{2}{|c|}{ Growth } & \multicolumn{2}{|c|}{ Value } \\
\hline & Coeff & $\mathrm{p}$-value & Coeff & $p$-value & Coeff & $\mathrm{p}$-value & Coeff & $\mathrm{p}$-value & Coeff & $\mathrm{p}$-value & Coeff & $\mathrm{p}$-value \\
\hline Following_std & $0.063 * * *$ & 0.000 & $0.066^{* * * *}$ & 0.000 & $0.063 * * *$ & 0.000 & $0.066^{* * * *}$ & 0.000 & $0.064 * * *$ & 0.000 & $0.064 * * *$ & 0.000 \\
\hline Constant & $0.595 * * *$ & 0.000 & $0.593^{* * * *}$ & 0.000 & $0.594 * * *$ & 0.000 & $0.593 * * *$ & 0.000 & $0.595^{* * *}$ & 0.000 & $0.594 * * *$ & 0.000 \\
\hline$R^{2}$ & 0.019 & & 0.019 & & 0.019 & & 0.019 & & 0.019 & & 0.019 & \\
\hline Observations & 67,427 & & 67,427 & & 67,427 & & 67,427 & & 67,427 & & 67,427 & \\
\hline
\end{tabular}

The dependent variable is Accuracy_std. Variable subscripts are omitted. Variables are defined in Appendix A. Estimates include year and GICS sector fixed effects. Standard errors are clustered by analyst. Twotailed $\mathrm{p}$-values are reported $* * * \mathrm{p}<0.01, * * \mathrm{p}<0.05, * \mathrm{p}<0.10$. $\mathrm{p}$-values in italics are reported using one-tailed $\mathrm{p}$-values. 
TABLE 9

The Effect of Firm-Level Ownership by Different Types Institution Types on and Earnings Forecast Properties

Panel A: Earnings Forecast Boldness

\begin{tabular}{|c|c|c|c|c|c|c|c|c|c|c|c|c|}
\hline \multirow[b]{2}{*}{ Variable } & \multicolumn{2}{|c|}{ All Institutions } & \multicolumn{2}{|c|}{ Transient } & \multicolumn{2}{|c|}{ Investment Advisor } & \multicolumn{2}{|c|}{$\begin{array}{l}\text { Transient Investment } \\
\text { Advisor }\end{array}$} & \multicolumn{2}{|c|}{ Growth } & \multicolumn{2}{|c|}{ Value } \\
\hline & Coeff & $\mathrm{p}$-value & Coeff & $\mathrm{p}$-value & Coeff & $p$-value & Coeff & $\mathrm{p}$-value & Coeff & $p$-value & Coeff & $\mathrm{p}$-value \\
\hline$X X_{-}$Inst_Inv_std & 0.002 & 0.961 & $0.098^{*}$ & 0.080 & 0.023 & 0.769 & $0.115 * *$ & 0.039 & -0.034 & 0.540 & 0.077 & 0.239 \\
\hline Non_XX_Inst_Inv_std & & & -0.086 & 0.140 & -0.018 & 0.823 & $-0.099 *$ & 0.087 & 0.028 & 0.612 & -0.076 & 0.278 \\
\hline$X X_{-} I n s t \_I n v$ & -0.001 & 0.692 & $-0.015^{* *}$ & 0.026 & $0.008 * *$ & 0.018 & -0.011 & 0.121 & -0.004 & 0.387 & $-0.019 * * *$ & 0.000 \\
\hline Non_XX_Inst_Inv & & & 0.004 & 0.106 & $-0.019 * * *$ & 0.010 & 0.002 & 0.329 & 0.000 & 0.782 & $0.008 * * *$ & 0.003 \\
\hline Days_Elapsed_std & $0.279 * * *$ & 0.000 & $0.280^{* * * *}$ & 0.000 & $0.281 * * *$ & 0.000 & $0.280^{* * *}$ & 0.000 & $0.278^{* * *}$ & 0.000 & $0.280^{* * *}$ & 0.000 \\
\hline Horizon_std & $0.583 * * *$ & 0.000 & $0.585^{* * *}$ & 0.000 & $0.579 * * *$ & 0.000 & $0.585^{* * *}$ & 0.000 & $0.583 * * *$ & 0.000 & $0.593 * * *$ & 0.000 \\
\hline Lag_Accuracy_std & $0.058 * *$ & 0.011 & $0.057^{* *}$ & 0.012 & $0.058 * *$ & 0.012 & $0.058^{* *}$ & 0.012 & $0.058 * *$ & 0.011 & $0.058 * *$ & 0.012 \\
\hline Firm_Exp_std & -0.013 & 0.626 & -0.012 & 0.660 & -0.014 & 0.610 & -0.013 & 0.641 & -0.013 & 0.641 & -0.013 & 0.641 \\
\hline Gen_Exp_std & -0.050 & 0.134 & -0.050 & 0.130 & -0.050 & 0.129 & -0.050 & 0.133 & -0.050 & 0.132 & -0.049 & 0.142 \\
\hline Forecast_Freq_std & $0.099 * * *$ & 0.000 & $0.099^{* * *}$ & 0.000 & $0.100^{* * * *}$ & 0.000 & $0.099^{* * *}$ & 0.000 & $0.099 * * *$ & 0.000 & $0.100^{* * *}$ & 0.000 \\
\hline Follow_std & 0.008 & 0.782 & 0.009 & 0.761 & 0.006 & 0.838 & 0.009 & 0.764 & 0.009 & 0.773 & 0.008 & 0.787 \\
\hline Sectors_std & $-0.126 * * *$ & 0.000 & $-0.124 * * *$ & 0.000 & $-0.124 * * *$ & 0.000 & $-0.124 * * *$ & 0.000 & $-0.126^{* * *}$ & 0.000 & $-0.122^{* * * *}$ & 0.000 \\
\hline Allstar & $0.076^{* *}$ & 0.037 & $0.072 * *$ & 0.050 & $0.077^{* *}$ & 0.035 & $0.073^{* *}$ & 0.047 & $0.076 * *$ & 0.037 & $0.072 * *$ & 0.048 \\
\hline Optimistic_Rec & -0.015 & 0.455 & -0.014 & 0.481 & -0.017 & 0.412 & -0.015 & 0.460 & -0.015 & 0.464 & -0.015 & 0.466 \\
\hline Brokerage_Size_std & -0.002 & 0.945 & -0.001 & 0.967 & -0.002 & 0.955 & -0.002 & 0.952 & -0.002 & 0.933 & -0.000 & 0.993 \\
\hline Underwriter & $0.156 * * *$ & 0.000 & $0.157^{* * *}$ & 0.000 & $0.157 * * *$ & 0.000 & $0.157 * * *$ & 0.000 & $0.156 * * *$ & 0.000 & $0.156^{* * * *}$ & 0.000 \\
\hline Guidance & $0.049 * *$ & 0.038 & $0.049 * *$ & 0.037 & $0.051^{* *}$ & 0.032 & $0.050^{* *}$ & 0.036 & $0.048 * *$ & 0.041 & $0.054 * *$ & 0.024 \\
\hline$A T \_s t d$ & $-0.133 * * *$ & 0.006 & $-0.134 * * *$ & 0.006 & $-0.134 * * *$ & 0.006 & $-0.133 * * *$ & 0.007 & $-0.136 * * *$ & 0.005 & $-0.130^{* * * *}$ & 0.008 \\
\hline IB_std & 0.059 & 0.116 & $0.062 *$ & 0.099 & 0.056 & 0.137 & 0.060 & 0.107 & 0.059 & 0.114 & $0.063^{*}$ & 0.094 \\
\hline$M V E_{-} s t d$ & $-0.221 * * *$ & 0.000 & $-0.212 * * *$ & 0.000 & $-0.231 * * *$ & 0.000 & $-0.212 * * *$ & 0.000 & $-0.210^{* * * *}$ & 0.000 & $-0.229^{* * * *}$ & 0.000 \\
\hline Spread_std & $-0.080 * * *$ & 0.005 & $-0.081 * * *$ & 0.004 & $-0.081 * * *$ & 0.004 & $-0.082 * * *$ & 0.004 & $-0.080^{* * * *}$ & 0.005 & $-0.082^{* * * *}$ & 0.004 \\
\hline Turnover_std & $0.094 * * *$ & 0.002 & $0.104 * * *$ & 0.001 & $0.092 * * *$ & 0.003 & $0.093 * * *$ & 0.003 & $0.095 * * *$ & 0.002 & $0.104 * * *$ & 0.001 \\
\hline News_Count_std & $0.264 * * *$ & 0.000 & $0.264 * * *$ & 0.000 & $0.263 * * *$ & 0.000 & $0.265^{* * * *}$ & 0.000 & $0.264 * * *$ & 0.000 & $0.264 * * *$ & 0.000 \\
\hline Following_std & 0.043 & 0.287 & 0.027 & 0.521 & 0.034 & 0.397 & 0.039 & 0.348 & 0.047 & 0.241 & 0.029 & 0.477 \\
\hline Constant & $-0.878 * * *$ & 0.000 & $-0.873 * * *$ & 0.000 & $-0.865^{* * *}$ & 0.000 & $-0.879 * * *$ & 0.000 & $-0.884 * * *$ & 0.000 & $-0.905^{* * *}$ & 0.000 \\
\hline ROC Curve & 0.620 & & 0.620 & & 0.620 & & 0.620 & & 0.620 & & 0.620 & \\
\hline Observations & 67,427 & & 67,427 & & 67,427 & & 67,427 & & 67,427 & & 67,427 & \\
\hline
\end{tabular}

The dependent variable is Bold. Variable subscripts are omitted. Variables are defined in Appendix A. Estimates include year and GICS sector fixed effects. Standard errors are clustered by analyst. Two-tailed pvalues are reported *** $\mathrm{p}<0.01, * * \mathrm{p}<0.05, * \mathrm{p}<0.10$. 
TABLE 9 (continued)

Panel B: Optimistic Earnings Forecast Boldness

\begin{tabular}{|c|c|c|c|c|c|c|c|c|c|c|c|c|}
\hline \multirow[b]{2}{*}{ Variable } & \multicolumn{2}{|c|}{ All Institutions } & \multicolumn{2}{|c|}{ Transient } & \multicolumn{2}{|c|}{ Investment Advisor } & \multicolumn{2}{|c|}{$\begin{array}{c}\text { Transient Investment } \\
\text { Advisor }\end{array}$} & \multicolumn{2}{|c|}{ Growth } & \multicolumn{2}{|c|}{ Value } \\
\hline & Coeff & $\mathrm{p}$-value & Coeff & $\mathrm{p}$-value & Coeff & $p$-value & Coeff & $\mathrm{p}$-value & Coeff & $p$-value & Coeff & $\mathrm{p}$-value \\
\hline$X X \_I n s t \_I n v \_s t d$ & $0.124 *$ & 0.058 & $0.337 * * *$ & 0.000 & $0.438^{* * * *}$ & 0.000 & $0.330^{* * * * *}$ & 0.000 & $0.144 *$ & 0.062 & 0.070 & 0.453 \\
\hline Non_XX_Inst_Inv_std & & & $-0.254 * * *$ & 0.002 & $-0.309 * * *$ & 0.003 & $-0.240^{* * * *}$ & 0.003 & 0.022 & 0.779 & 0.050 & 0.604 \\
\hline$X X_{-} I n s t \_I n v$ & -0.002 & 0.363 & $0.070^{* * * *}$ & 0.000 & 0.001 & 0.863 & $0.078^{* * * *}$ & 0.000 & $-0.020 * * * *$ & 0.002 & 0.005 & 0.483 \\
\hline Non_XX_Inst_Inv & & & $-0.023 * * *$ & 0.000 & -0.006 & 0.555 & $-0.021 * * *$ & 0.000 & 0.003 & 0.171 & -0.005 & 0.185 \\
\hline Days_Elapsed_std & $0.168 * * *$ & 0.000 & $0.164 * * *$ & 0.000 & $0.168^{* * * *}$ & 0.000 & $0.163^{* * * *}$ & 0.000 & $0.167 * * *$ & 0.000 & $0.167^{* * * *}$ & 0.000 \\
\hline Horizon_std & $0.413 * * *$ & 0.000 & $0.406 * * *$ & 0.000 & $0.411 * * *$ & 0.000 & $0.407 * * *$ & 0.000 & $0.413 * * *$ & 0.000 & $0.409^{* * * *}$ & 0.000 \\
\hline Lag_Accuracy_std & $0.149^{* * * *}$ & 0.000 & $0.155^{* * * *}$ & 0.000 & $0.149 * * *$ & 0.000 & $0.154 * * *$ & 0.000 & $0.149 * * *$ & 0.000 & $0.149^{* * * *}$ & 0.000 \\
\hline Gen_Exp_std & $-0.126 * * *$ & 0.006 & $-0.123^{* * *}$ & 0.007 & $-0.125 * * *$ & 0.006 & $-0.123^{* * *}$ & 0.007 & $-0.127 * * *$ & 0.006 & $-0.127^{* * *}$ & 0.006 \\
\hline Forecast_Freq_std & $0.063 *$ & 0.057 & $0.056 *$ & 0.087 & $0.062 *$ & 0.058 & $0.056^{*}$ & 0.087 & $0.062 *$ & 0.061 & $0.062 *$ & 0.060 \\
\hline Follow_std & $0.073 *$ & 0.074 & $0.067 *$ & 0.100 & $0.069^{*}$ & 0.093 & $0.068^{*}$ & 0.093 & $0.075^{*}$ & 0.067 & $0.074 *$ & 0.069 \\
\hline Sectors_std & $-0.087^{* *}$ & 0.014 & $-0.093^{* * *}$ & 0.009 & $-0.088^{* *}$ & 0.013 & $-0.094 * * *$ & 0.008 & $-0.088^{* *}$ & 0.013 & $-0.088^{* *}$ & 0.013 \\
\hline Allstar & $0.105 * *$ & 0.031 & $0.123 * *$ & 0.011 & $0.108 * *$ & 0.027 & $0.126^{* * * *}$ & 0.010 & $0.108 * *$ & 0.027 & $0.106 * *$ & 0.029 \\
\hline Optimistic_Rec & $0.095 * * *$ & 0.001 & $0.082 * * *$ & 0.003 & $0.093 * * *$ & 0.001 & $0.082 * * *$ & 0.003 & $0.094 * * *$ & 0.001 & $0.095 * * *$ & 0.001 \\
\hline Brokerage_Size_std & 0.001 & 0.975 & -0.004 & 0.917 & 0.001 & 0.979 & -0.006 & 0.886 & 0.000 & 0.998 & -0.000 & 0.999 \\
\hline Underwriter & 0.052 & 0.169 & 0.054 & 0.150 & 0.051 & 0.173 & 0.054 & 0.152 & 0.051 & 0.175 & 0.052 & 0.166 \\
\hline Guidance & $0.071^{* *}$ & 0.036 & $0.076 * *$ & 0.024 & $0.072^{* *}$ & 0.032 & $0.075^{* *}$ & 0.027 & $0.069^{* *}$ & 0.040 & $0.068 * *$ & 0.044 \\
\hline$A T_{-} s t d$ & $-0.442 * * *$ & 0.000 & $-0.401 * * *$ & 0.000 & $-0.444 * * *$ & 0.000 & $-0.400 * * *$ & 0.000 & $-0.441 * * *$ & 0.000 & $-0.448^{* * * *}$ & 0.000 \\
\hline Spread_std & $0.103 * * *$ & 0.008 & $0.090 * *$ & 0.020 & $0.104 * * *$ & 0.007 & $0.090^{* * *}$ & 0.020 & $0.101 * * *$ & 0.009 & $0.104^{* * * *}$ & 0.007 \\
\hline Turnover_std & $0.084 *$ & 0.051 & $-0.099 * *$ & 0.026 & 0.063 & 0.142 & $-0.093^{* *}$ & 0.036 & $0.072 *$ & 0.092 & $0.081 *$ & 0.060 \\
\hline News_Count_std & $0.155 * * *$ & 0.003 & $0.168^{* * * *}$ & 0.001 & $0.156 * * *$ & 0.003 & $0.166 * * *$ & 0.001 & $0.155^{* * * *}$ & 0.003 & $0.154 * * *$ & 0.003 \\
\hline Following_std & -0.046 & 0.427 & $0.143 * *$ & 0.018 & -0.036 & 0.529 & $0.153 * *$ & 0.012 & -0.032 & 0.585 & -0.040 & 0.494 \\
\hline Constant & $-1.852 * * *$ & 0.000 & $-1.955^{* * *}$ & 0.000 & $-1.841 * * *$ & 0.000 & $-1.988 * * *$ & 0.000 & $-1.868 * * *$ & 0.000 & $-1.847 * * *$ & 0.000 \\
\hline ROC Curve & 0.644 & & 0.651 & & 0.645 & & 0.650 & & 0.644 & & 0.644 & \\
\hline Observations & 67,427 & & 67,427 & & 67,427 & & 67,427 & & 67,427 & & 67,427 & \\
\hline
\end{tabular}

The dependent variable is Optimistic_Bold. Variable subscripts are omitted. Variables are defined in Appendix A. Estimates include year and GICS sector fixed effects. Standard errors are clustered by analyst. Twotailed p-values are reported ${ }^{* * *} \mathrm{p}<0.01,{ }^{* *} \mathrm{p}<0.05,{ }^{*} \mathrm{p}<0.10$. (continued on next page) 
TABLE 9 (continued)

Panel C: Earnings Forecast Accuracy

\begin{tabular}{|c|c|c|c|c|c|c|c|c|c|c|c|c|}
\hline \multirow[b]{2}{*}{ Variable } & \multicolumn{2}{|c|}{ All Institutions } & \multicolumn{2}{|c|}{ Transient } & \multicolumn{2}{|c|}{ Investment Advisor } & \multicolumn{2}{|c|}{$\begin{array}{c}\text { Transient Investment } \\
\text { Advisor }\end{array}$} & \multicolumn{2}{|c|}{ Growth } & \multicolumn{2}{|c|}{ Value } \\
\hline & Coeff & $\mathrm{p}$-value & Coeff & $\mathrm{p}$-value & Coeff & $p$-value & Coeff & $\mathrm{p}$-value & Coeff & $\mathrm{p}$-value & Coeff & $p$-value \\
\hline$X X_{-}$Inst_Inv_std & $0.020 * *$ & 0.010 & 0.040 **** & 0.000 & -0.011 & 0.441 & $0.039 * * * *$ & 0.000 & 0.000 & 0.967 & $0.025 * *$ & 0.035 \\
\hline Non_XX_Inst_Inv_std & & & -0.012 & 0.889 & $0.034 * * *$ & 0.008 & -0.009 & 0.830 & $0.020 \% *$ & 0.023 & -0.004 & 0.622 \\
\hline$X X_{-} I n s t \_I n v$ & 0.000 & 0.980 & $-0.005 * * *$ & 0.000 & $0.002 * * *$ & 0.002 & $-0.005 * * *$ & 0.000 & 0.001 & 0.212 & -0.002 & 0.124 \\
\hline Non_XX_Inst_Inv & & & $0.001 * * *$ & 0.000 & -0.004 & 0.997 & $0.001 * * *$ & 0.000 & 0.000 & 0.760 & $0.001 * *$ & 0.035 \\
\hline Bold_lstd & $-0.051 * * *$ & 0.000 & $-0.051^{* * * *}$ & 0.000 & $-0.051 * * *$ & 0.000 & $-0.051^{* * * *}$ & 0.000 & $-0.051^{* * * *}$ & 0.000 & $-0.051^{* * * *}$ & 0.000 \\
\hline Days_Elapsed_std & 0.000 & 0.995 & 0.001 & 0.892 & 0.001 & 0.880 & 0.001 & 0.884 & 0.000 & 0.976 & 0.000 & 0.952 \\
\hline Horizon_std & $-0.031 * * *$ & 0.000 & $-0.030 * * *$ & 0.000 & $-0.032 * * *$ & 0.000 & $-0.030 * * *$ & 0.000 & $-0.031 * * *$ & 0.000 & $-0.030 * * *$ & 0.000 \\
\hline Lag_Accuracy_std & $0.081 * * *$ & 0.000 & $0.080 * * *$ & 0.000 & $0.080 * * *$ & 0.000 & $0.080 * * *$ & 0.000 & $0.081 * * *$ & 0.000 & $0.081 * * *$ & 0.000 \\
\hline Firm_Exp_std & $0.009 *$ & 0.058 & $0.010 * *$ & 0.046 & $0.010^{*}$ & 0.053 & $0.010^{* *}$ & 0.046 & $0.010 *$ & 0.056 & $0.010 *$ & 0.053 \\
\hline Gen_Exp_std & 0.003 & 0.628 & 0.003 & 0.655 & 0.002 & 0.661 & 0.003 & 0.647 & 0.003 & 0.639 & 0.003 & 0.623 \\
\hline Forecast_Freq_std & $0.012 * * *$ & 0.004 & $0.012 * * *$ & 0.003 & $0.012 * * *$ & 0.003 & $0.012 * * *$ & 0.003 & $0.012 * * *$ & 0.004 & $0.012 * * *$ & 0.004 \\
\hline Follow_std & 0.001 & 0.870 & 0.001 & 0.806 & 0.001 & 0.877 & 0.001 & 0.796 & 0.001 & 0.862 & 0.001 & 0.835 \\
\hline Sectors_std & $-0.010 * *$ & 0.019 & $-0.009 * *$ & 0.031 & $-0.009 * *$ & 0.029 & $-0.009 * *$ & 0.032 & $-0.009 * *$ & 0.020 & $-0.009 * *$ & 0.024 \\
\hline Allstar & -0.002 & 0.663 & -0.004 & 0.474 & -0.002 & 0.664 & -0.004 & 0.474 & -0.002 & 0.647 & -0.003 & 0.609 \\
\hline Optimistic_Rec & 0.002 & 0.512 & 0.003 & 0.463 & 0.002 & 0.551 & 0.003 & 0.459 & 0.002 & 0.508 & 0.002 & 0.503 \\
\hline Brokerage_Size_std & -0.005 & 0.356 & -0.004 & 0.391 & -0.005 & 0.369 & -0.004 & 0.384 & -0.005 & 0.357 & -0.004 & 0.373 \\
\hline Underwriter & 0.002 & 0.701 & 0.002 & 0.672 & 0.002 & 0.669 & 0.002 & 0.672 & 0.002 & 0.702 & 0.002 & 0.704 \\
\hline Guidance & $0.027 * * *$ & 0.000 & $0.027 * * *$ & 0.000 & $0.027 * * *$ & 0.000 & $0.027 * * *$ & 0.000 & $0.027 * * *$ & 0.000 & $0.027 * * *$ & 0.000 \\
\hline$A T_{-} s t d$ & 0.011 & 0.167 & 0.010 & 0.199 & 0.011 & 0.166 & 0.010 & 0.207 & 0.011 & 0.167 & 0.010 & 0.196 \\
\hline IB_std & $-0.018 * * *$ & 0.004 & $-0.017 * * *$ & 0.007 & $-0.017 * * *$ & 0.005 & $-0.017 * * *$ & 0.007 & $-0.018 * * *$ & 0.005 & $-0.017 * * *$ & 0.005 \\
\hline$M V E \_s t d$ & $-0.017 *$ & 0.072 & -0.015 & 0.125 & $-0.017^{*}$ & 0.071 & -0.015 & 0.118 & $-0.017 *$ & 0.083 & $-0.016 *$ & 0.098 \\
\hline Spread_std & 0.000 & 0.977 & -0.000 & 0.994 & -0.000 & 0.988 & -0.000 & 0.983 & 0.000 & 0.975 & -0.000 & 0.996 \\
\hline Turnover_std & $-0.009 *$ & 0.080 & -0.006 & 0.273 & -0.008 & 0.126 & -0.006 & 0.257 & $-0.009^{*}$ & 0.094 & -0.008 & 0.114 \\
\hline News_Count_std & $0.016 * *$ & 0.013 & $0.015^{* *}$ & 0.016 & $0.015 * *$ & 0.018 & $0.015^{* *}$ & 0.015 & $0.016 * *$ & 0.014 & $0.015 * *$ & 0.015 \\
\hline Following_std & $0.063 * * *$ & 0.000 & $0.059^{* * * *}$ & 0.000 & $0.061 * * *$ & 0.000 & $0.059 * * *$ & 0.000 & $0.063^{* * * *}$ & 0.000 & $0.062 * * *$ & 0.000 \\
\hline Constant & $0.594 * * *$ & 0.000 & $0.596 * * *$ & 0.000 & $0.596^{* * *}$ & 0.000 & $0.596 * * *$ & 0.000 & $0.595 * * *$ & 0.000 & $0.591 * * *$ & 0.000 \\
\hline$R^{2}$ & 0.019 & & 0.019 & & 0.019 & & 0.019 & & 0.019 & & 0.019 & \\
\hline Observations & 67,427 & & 67,427 & & 67,427 & & 67,427 & & 67,427 & & 67,427 & \\
\hline
\end{tabular}

The dependent variable is Accuracy_std. Variable subscripts are omitted. Variables are defined in Appendix A. Estimates include year and GICS sector fixed effects. Standard errors are clustered by analyst. Twotailed $\mathrm{p}$-values are reported ${ }^{* * *} \mathrm{p}<0.01,{ }^{* *} \mathrm{p}<0.05,{ }^{*} \mathrm{p}<0.10$. $\mathrm{p}$-values in italics are reported using one-tailed $\mathrm{p}$-values. 
TABLE 10

The Effect of Ownership by Different Institution Types on Earnings Forecast Properties without Blockholder

Panel A: Earnings Forecast Boldness

\begin{tabular}{|c|c|c|c|c|c|c|c|c|c|c|c|c|}
\hline \multirow[b]{2}{*}{ Variable } & \multicolumn{2}{|c|}{ All Institutions } & \multicolumn{2}{|c|}{ Transient } & \multicolumn{2}{|c|}{ Investment Advisor } & \multicolumn{2}{|c|}{$\begin{array}{l}\text { Transient Investment } \\
\text { Advisor }\end{array}$} & \multicolumn{2}{|c|}{ Growth } & \multicolumn{2}{|c|}{ Value } \\
\hline & Coeff & $p$-value & Coeff & $\mathrm{p}$-value & Coeff & $p$-value & Coeff & $p$-value & Coeff & $p$-value & Coeff & $p$-value \\
\hline$X X \_I n s t$ Inv_std & -0.006 & 0.871 & 0.035 & 0.457 & 0.102 & 0.155 & 0.068 & 0.148 & $\begin{array}{l}-0.061 \\
\end{array}$ & 0.255 & -0.001 & 0.986 \\
\hline Days_Elapsed_std & $0.278 * * *$ & 0.000 & $0.279 * * *$ & 0.000 & $0.278 * * *$ & 0.000 & $0.279^{* * *}$ & 0.000 & $0.278^{* * * *}$ & 0.000 & $0.279^{* * *}$ & 0.000 \\
\hline Horizon_std & $0.583 * * *$ & 0.000 & $0.583 * * *$ & 0.000 & $0.583 * * *$ & 0.000 & $0.583^{* * *}$ & 0.000 & $0.583 * * *$ & 0.000 & $0.583^{* * *}$ & 0.000 \\
\hline Lag_Accuracy_std & $0.058 * *$ & 0.011 & $0.058 * *$ & 0.011 & $0.058^{* *}$ & 0.011 & $0.058 * *$ & 0.011 & $0.058 * *$ & 0.012 & $0.058 * *$ & 0.011 \\
\hline Firm_Exp_std & -0.013 & 0.636 & -0.013 & 0.628 & -0.014 & 0.612 & -0.014 & 0.622 & -0.013 & 0.648 & -0.013 & 0.639 \\
\hline Gen_Exp_std & -0.050 & 0.130 & -0.050 & 0.130 & -0.050 & 0.132 & -0.050 & 0.131 & -0.050 & 0.130 & -0.051 & 0.128 \\
\hline Follow_std & 0.008 & 0.797 & 0.008 & 0.799 & 0.007 & 0.824 & 0.008 & 0.798 & 0.008 & 0.792 & 0.008 & 0.794 \\
\hline Sectors_std & $-0.126 * * *$ & 0.000 & $-0.126^{* * *}$ & 0.000 & $-0.126 * * *$ & 0.000 & $-0.125^{* * *}$ & 0.000 & $-0.126^{* * *}$ & 0.000 & $-0.126^{* * *}$ & 0.000 \\
\hline Allstar & $0.074 * *$ & 0.039 & $0.074 * *$ & 0.039 & $0.076 * *$ & 0.036 & $0.074 * *$ & 0.040 & $0.074 * *$ & 0.040 & $0.075^{* *}$ & 0.039 \\
\hline Optimistic_Rec & -0.015 & 0.459 & -0.015 & 0.448 & -0.015 & 0.448 & -0.016 & 0.440 & -0.015 & 0.471 & -0.015 & 0.461 \\
\hline Brokerage_Size_std & -0.002 & 0.946 & -0.002 & 0.937 & -0.002 & 0.944 & -0.002 & 0.933 & -0.002 & 0.938 & -0.002 & 0.938 \\
\hline Underwriter & $0.156^{* * *}$ & 0.000 & $0.157 * * *$ & 0.000 & $0.156 * * *$ & 0.000 & $0.157^{* * * *}$ & 0.000 & $0.156^{* * * *}$ & 0.000 & $0.156^{* * * *}$ & 0.000 \\
\hline Guidance & $0.049 * *$ & 0.039 & $0.049 * *$ & 0.037 & $0.049 * *$ & 0.037 & $0.049 * *$ & 0.037 & $0.048 * *$ & 0.041 & $0.049 * *$ & 0.039 \\
\hline$A T \_s t d$ & $-0.135 * * *$ & 0.006 & $-0.132 * * *$ & 0.007 & $-0.135 * * *$ & 0.006 & $-0.132 * * *$ & 0.007 & $-0.137 * * *$ & 0.005 & $-0.135^{* * * *}$ & 0.006 \\
\hline$I B_{-} s t d$ & 0.60 & 0.112 & 0.060 & 0.112 & 0.056 & 0.137 & 0.059 & 0.116 & 0.060 & 0.110 & 0.060 & 0.111 \\
\hline$M V E \_s t d$ & $-0.223 * * *$ & 0.000 & $-0.217 * * *$ & 0.000 & $-0.231 * * *$ & 0.000 & $-0.216 * * *$ & 0.000 & $-0.208 * * *$ & 0.000 & $-0.222 * * *$ & 0.000 \\
\hline Turnover_std & $0.096 * * *$ & 0.002 & $0.089 * * *$ & 0.005 & $0.089 * * *$ & 0.004 & $0.085^{* * *}$ & 0.007 & $0.098^{* * * *}$ & 0.004 & $0.096^{* * *}$ & 0.002 \\
\hline News_Count_std & $0.262 * * *$ & 0.000 & $0.264 * * *$ & 0.000 & $0.264 * * *$ & 0.000 & $0.264^{* * *}$ & 0.000 & $0.262 * * *$ & 0.000 & $0.262 * * *$ & 0.000 \\
\hline Following_std & 0.044 & 0.267 & 0.047 & 0.251 & 0.045 & 0.255 & 0.054 & 0.192 & 0.047 & 0.244 & 0.044 & 0.272 \\
\hline Constant & $-0.882 * * *$ & 0.000 & $-0.883^{* * *}$ & 0.000 & $-0.876^{* * *}$ & 0.000 & $-0.890 * * *$ & 0.000 & $-0.885^{* * *}$ & 0.000 & $-0.882^{* * *}$ & 0.000 \\
\hline ROC Curve & 0.620 & & 0.620 & & 0.620 & & 0.620 & & 0.620 & & 0.620 & \\
\hline Observations & 67,427 & & 67,427 & & 67,427 & & 67,427 & & 67,427 & & 67,427 & \\
\hline
\end{tabular}

The dependent variable is Bold. Variable subscripts are omitted. Variables are defined in Appendix A. Estimates include year and GICS sector fixed effects. Standard errors are clustered by analyst. Two-tailed pvalues are reported $* * * \mathrm{p}<0.01, * * \mathrm{p}<0.05, * \mathrm{p}<0.10$. 
TABLE 10 (continued)

Panel B: Optimistic Earnings Forecast Boldnes

\begin{tabular}{|c|c|c|c|c|c|c|c|c|c|c|c|c|}
\hline \multirow[b]{2}{*}{ Variable } & \multicolumn{2}{|c|}{ All Institutions } & \multicolumn{2}{|c|}{ Transient } & \multicolumn{2}{|c|}{ Investment Advisor } & \multicolumn{2}{|c|}{$\begin{array}{l}\text { Transient Investment } \\
\text { Advisor }\end{array}$} & \multicolumn{2}{|c|}{ Growth } & \multicolumn{2}{|c|}{ Value } \\
\hline & Coeff & $\mathrm{p}$-value & Coeff & $p$-value & Coeff & $\mathrm{p}$-value & Coeff & $\mathrm{p}$-value & Coeff & $\mathrm{p}$-value & Coeff & $p$-value \\
\hline$X X_{-}$Inst_Inv_std & $0.097 *$ & 0.075 & $0.617 * * *$ & 0.000 & $0.427 * * * *$ & 0.000 & $0.594 * * *$ & 0.000 & 0.058 & 0.432 & 0.094 & 0.267 \\
\hline Non_XX_Inst_Inv_std & & & $-0.499 * * *$ & 0.000 & $-0.323 * * *$ & 0.000 & $-0.459 * * *$ & 0.000 & 0.048 & 0.513 & -0.002 & 0.985 \\
\hline Days_Elapsed_std & $0.168 * * *$ & 0.000 & $0.170 * * *$ & 0.000 & $0.167 * * *$ & 0.000 & $0.170 * * *$ & 0.000 & $0.168^{* * * *}$ & 0.000 & $0.168 * * *$ & 0.000 \\
\hline Horizon_std & $0.413^{* * * *}$ & 0.000 & $0.415 * * *$ & 0.000 & $0.412^{* * * *}$ & 0.000 & $0.415 * * *$ & 0.000 & $0.413^{* * * *}$ & 0.000 & $0.413 * * *$ & 0.000 \\
\hline Lag_Accuracy_std & $0.149^{* * *}$ & 0.000 & $0.152 * * *$ & 0.000 & $0.149^{* * * *}$ & 0.000 & $0.151^{* * *}$ & 0.000 & $0.149^{* * *}$ & 0.000 & $0.149 * * *$ & 0.000 \\
\hline Firm_Exp_std & 0.061 & 0.106 & 0.057 & 0.132 & 0.058 & 0.126 & 0.056 & 0.136 & 0.061 & 0.106 & 0.062 & 0.104 \\
\hline Gen_Exp_std & $-0.128 * * *$ & 0.005 & $-0.126^{* * * *}$ & 0.006 & $-0.126 * * *$ & 0.006 & $-0.126^{* * *}$ & 0.006 & $-0.128 * * *$ & 0.005 & $-0.128^{* * * *}$ & 0.005 \\
\hline Follow_std & $0.071 *$ & 0.083 & $0.071 *$ & 0.083 & 0.067 & 0.100 & $0.073^{*}$ & 0.075 & $0.071 *$ & 0.081 & $0.072 *$ & 0.078 \\
\hline Sectors_std & $-0.087 * *$ & 0.015 & $-0.081 * *$ & 0.023 & $-0.088 * *$ & 0.013 & $-0.081 * *$ & 0.022 & $-0.086 * *$ & 0.015 & $-0.086 * *$ & 0.015 \\
\hline Allstar & $0.100 * *$ & 0.040 & $0.096 * *$ & 0.049 & $0.104 * *$ & 0.033 & $0.098 * *$ & 0.045 & $0.100 * *$ & 0.039 & $0.100 * *$ & 0.040 \\
\hline Optimistic_Rec & $0.095^{* * * *}$ & 0.000 & $0.089 * * *$ & 0.001 & $0.094 * * *$ & 0.001 & $0.089 * * *$ & 0.001 & $0.095^{* * * *}$ & 0.000 & $0.095 * * *$ & 0.000 \\
\hline Brokerage_Size_std & 0.001 & 0.971 & 0.002 & 0.960 & 0.002 & 0.964 & 0.000 & 0.992 & 0.001 & 0.979 & 0.001 & 0.981 \\
\hline Underwriter & 0.053 & 0.159 & 0.058 & 0.123 & 0.052 & 0.169 & 0.058 & 0.125 & 0.053 & 0.158 & 0.053 & 0.157 \\
\hline Guidance & $0.069^{* *}$ & 0.039 & $0.074 * *$ & 0.028 & $0.071^{* *}$ & 0.035 & $0.073 * *$ & 0.030 & $0.070 * *$ & 0.037 & $0.069 * *$ & 0.040 \\
\hline$A T_{-} s t d$ & $-0.446 * * *$ & 0.000 & $-0.424 * * *$ & 0.000 & $-0.447 * * *$ & 0.000 & $-0.426 * * *$ & 0.000 & $-0.444 * * *$ & 0.000 & $-0.451 * * *$ & 0.000 \\
\hline IB_std & 0.076 & 0.144 & 0.074 & 0.156 & 0.061 & 0.240 & 0.071 & 0.173 & 0.076 & 0.145 & 0.076 & 0.143 \\
\hline$M V E \_s t d$ & $0.360^{* * * *}$ & 0.000 & $0.401 * * *$ & 0.000 & $0.330^{* * *}$ & 0.000 & $0.400 * * *$ & 0.000 & $0.351^{* * * *}$ & 0.000 & $0.375 * * *$ & 0.000 \\
\hline News_Count_std & $0.150^{* * * *}$ & 0.004 & $0.156 * * *$ & 0.003 & $0.153^{* * * *}$ & 0.003 & $0.156^{* * *}$ & 0.003 & $0.150^{* * *}$ & 0.004 & $0.150 * * *$ & 0.004 \\
\hline Following_std & -0.042 & 0.463 & 0.039 & 0.508 & -0.035 & 0.546 & 0.048 & 0.417 & -0.044 & 0.440 & -0.041 & 0.474 \\
\hline Constant & $-1.864 * * *$ & 0.000 & $-1.928 * * *$ & 0.000 & $-1.850 * * *$ & 0.000 & $-1.943 * * *$ & 0.000 & $-1.863 * * *$ & 0.000 & $-1.869^{* * *}$ & 0.000 \\
\hline ROC Curve & 0.644 & & 0.647 & & 0.645 & & 0.647 & & 0.644 & & 0.644 & \\
\hline Observations & 67,427 & & 67,427 & & 67,427 & & 67,427 & & 67,427 & & 67,427 & \\
\hline
\end{tabular}

The dependent variable is Optimistic_Bold. Variable subscripts are omitted. Variables are defined in Appendix A. Estimates include year and GICS sector fixed effects. Standard errors are clustered by analyst. Twotailed $\mathrm{p}$-values are reported $* * \mathrm{p}<0.01, * * \mathrm{p}<0.05, * \mathrm{p}<0.10$ 
TABLE 10 (continued)

Panel C: Earnings Forecast Accuracy

\begin{tabular}{|c|c|c|c|c|c|c|c|c|c|c|c|c|}
\hline \multirow[b]{2}{*}{ Variable } & \multicolumn{2}{|c|}{ All Institutions } & \multicolumn{2}{|c|}{ Transient } & \multicolumn{2}{|c|}{ Investment Advisor } & \multicolumn{2}{|c|}{$\begin{array}{c}\text { Transient Investment } \\
\text { Advisor }\end{array}$} & \multicolumn{2}{|c|}{ Growth } & \multicolumn{2}{|c|}{ Value } \\
\hline & Coeff & $p$-value & Coeff & $p$-value & Coeff & $p$-value & Coeff & $p$-value & Coeff & $p$-value & Coeff & $p$-value \\
\hline$X X \_I n s t \_I n v \_s t d$ & 0.020 **** & 0.003 & $0.020^{* * *}$ & 0.013 & 0.005 & 0.696 & $0.020 * *$ & 0.012 & 0.007 & 0.459 & $0.018 *$ & 0.078 \\
\hline Non_XX_Inst_Inv_std & & & 0.003 & 0.364 & $0.017 *$ & 0.087 & 0.003 & 0.353 & $0.015 * *$ & 0.040 & 0.003 & 0.366 \\
\hline Bold & $-0.051 * * *$ & 0.000 & $-0.051 * * *$ & 0.000 & $-0.051 * * *$ & 0.000 & $-0.051^{* * *}$ & 0.000 & $-0.051 * * *$ & 0.000 & $-0.051 * * *$ & 0.000 \\
\hline Days_Elapsed_std & 0.000 & 0.995 & 0.000 & 0.974 & 0.000 & 0.984 & 0.000 & 0.974 & 0.000 & 0.985 & 0.000 & 0.984 \\
\hline Horizon_std & $-0.031^{* * *}$ & 0.000 & $-0.031 * * *$ & 0.000 & $-0.031 * * *$ & 0.000 & $-0.031^{* * *}$ & 0.000 & $-0.031 * * *$ & 0.000 & $-0.031 * * *$ & 0.000 \\
\hline Lag_Accuracy_std & $0.081 * * *$ & 0.000 & $0.081^{* * *}$ & 0.000 & $0.081 * * *$ & 0.000 & $0.081^{* * * *}$ & 0.000 & $0.081 * * *$ & 0.000 & $0.081^{* * * *}$ & 0.000 \\
\hline Firm_Exp_std & $0.009 *$ & 0.059 & $0.009 *$ & 0.059 & $0.010^{*}$ & 0.054 & $0.009 *$ & 0.059 & $0.010 *$ & 0.057 & $0.010 *$ & 0.055 \\
\hline Forecast_Freq_std & $0.012 * * *$ & 0.004 & $0.012^{* * * *}$ & 0.004 & $0.012^{* * *}$ & 0.004 & $0.012 * * *$ & 0.004 & $0.012 * * *$ & 0.004 & $0.012 * * *$ & 0.004 \\
\hline Follow_std & 0.001 & 0.871 & 0.001 & 0.860 & 0.001 & 0.850 & 0.001 & 0.855 & 0.001 & 0.857 & 0.001 & 0.837 \\
\hline Sectors_std & $-0.010^{* *}$ & 0.019 & $-0.009 * *$ & 0.021 & $-0.009 * *$ & 0.020 & $-0.009 * *$ & 0.021 & $-0.010 * *$ & 0.019 & $-0.010^{* *}$ & 0.019 \\
\hline Allstar & -0.002 & 0.672 & -0.002 & 0.649 & -0.002 & 0.654 & -0.002 & 0.654 & -0.002 & 0.672 & -0.002 & 0.665 \\
\hline Optimistic_Rec & 0.002 & 0.514 & 0.002 & 0.535 & 0.002 & 0.505 & 0.002 & 0.536 & 0.002 & 0.512 & 0.002 & 0.506 \\
\hline Brokerage_Size_std & -0.005 & 0.358 & -0.005 & 0.354 & -0.005 & 0.355 & -0.005 & 0.350 & -0.005 & 0.354 & -0.005 & 0.354 \\
\hline Underwriter & 0.002 & 0.703 & 0.002 & 0.687 & 0.002 & 0.702 & 0.002 & 0.687 & 0.02 & 0.706 & 0.002 & 0.701 \\
\hline Guidance & $0.027 * * *$ & 0.000 & $0.027 * * *$ & 0.000 & $0.027 * * *$ & 0.000 & $0.027 * * *$ & 0.000 & $0.027 * * *$ & 0.000 & $0.027 * * *$ & 0.000 \\
\hline$A T_{-} s t d$ & 0.011 & 0.162 & 0.011 & 0.158 & 0.011 & 0.167 & 0.011 & 0.158 & 0.011 & 0.164 & 0.010 & 0.208 \\
\hline IB_std & $-0.018^{* * * *}$ & 0.004 & $-0.018 * * *$ & 0.004 & $-0.017 * * *$ & 0.005 & $-0.018 * * *$ & 0.004 & $-0.018 * * *$ & 0.004 & $-0.018 * * *$ & 0.004 \\
\hline Spread_std & 0.000 & 0.976 & 0.000 & 0.984 & 0.000 & 0.990 & 0.000 & 0.980 & 0.000 & 0.980 & 0.000 & 0.969 \\
\hline Turnover_std & $-0.009 *$ & 0.074 & $-0.011 * *$ & 0.035 & $-0.009 *$ & 0.096 & $-0.012^{* *}$ & 0.032 & $-0.009 *$ & 0.071 & $-0.009 *$ & 0.077 \\
\hline News_Count_std & $0.016^{* *}$ & 0.014 & $0.016^{* *}$ & 0.014 & $0.015^{* *}$ & 0.016 & $0.016^{* *}$ & 0.014 & $0.016^{* *}$ & 0.014 & $0.016 * *$ & 0.015 \\
\hline Following_std & $0.063^{* * * *}$ & 0.000 & $0.065^{* * * *}$ & 0.000 & $0.063^{* * * *}$ & 0.000 & $0.066^{* * *}$ & 0.000 & $0.063^{* * * *}$ & 0.000 & $0.064 * * *$ & 0.000 \\
\hline Constant & $0.595^{* * * *}$ & 0.000 & $0.593^{* * * *}$ & 0.000 & $0.594 * * *$ & 0.000 & $0.592 * * *$ & 0.000 & $0.594 * * *$ & 0.000 & $0.593^{* * * *}$ & 0.000 \\
\hline$R^{2}$ & 0.019 & & 0.019 & & 0.019 & & 0.019 & & 0.019 & & 0.019 & \\
\hline Observations & 67,427 & & 67,427 & & 67,427 & & 67,427 & & 67,427 & & 67,427 & \\
\hline
\end{tabular}

The dependent variable is Accuracy_std. Variable subscripts are omitted. Variables are defined in Appendix A. Estimates include year and GICS sector fixed effects. Standard errors are clustered by analyst. Two-tailed p-values are reported $* * * \mathrm{p}<0.01, * * \mathrm{p}<0.05,{ }^{*} \mathrm{p}<0.10$. $\mathrm{p}$-values in italics are reported using one-tailed $\mathrm{p}$-values. 